\title{
Culture, Institutions AND The WEALTh OF NATIONS
}

\author{
Yuriy Gorodnichenko \\ University of California, Berkeley and NBER
}

\author{
Gerard Roland \\ University of California, Berkeley, NBER and \\ CEPR
}

\begin{abstract}
We explore the link between the individualism-collectivism dimension of culture and innovation and long-run growth. We argue that a more individualist culture leads to more innovation and to higher growth because of the social status rewards associated with innovation in that culture. For our baseline estimates, we use data on the frequency of particular genes associated with collectivist cultures, as well as a measure of distance in terms of frequencies of blood types, and historic prevalence of pathogens to instrument individualism scores. The relationship between individualism and innovation/growth remains strong even after controlling for institutions and other potentially confounding factors. We also provide evidence consistent with two-way causality between culture and institutions.
\end{abstract}

Acknowledgments: We thank Vladimir Asriyan, Dominick Bartelme, Insook Lee, and Donna Kim for excellent research assistance. We are grateful to three referees for extensive comments. We benefited from discussions with Philippe Aghion, Yann Algan, John Bonin, Olivier Coibion, Lewis Davis, Lena Edlund, Fred Finan, David Laitin, Amir Licht, Edward Miguel, Gerard Padro-I-Miquel, David Romer, Guido Tabellini, Daniel Treisman, Luigi Zingales, and seminar participants at UC Berkeley, the Booth School of Business, Michigan, the Harvard-MIT Development seminar, IMT Lucca, the University of Sienna, Stanford, Princeton, UCLA Anderson School of Business, Sciences Po Paris, the European University Institute, Facultés Universitaires Notre Dame de la Paix in Namur, Solvay Business School of Economics and Management, the "Macroeconomic Across Time and Space" conference, the Berkeley Center for Political Economy conference on Endogenous Institutions, the NBER Workshop in Political Economy and the National Academy of Sciences Sackler Colloquium on "Dynamics of Social, Political, and Economic Institutions", conference participants in the First Annual conference of Belgian economists in 2010 and the 2011 AEA meetings. We are especially grateful to Romain Wacziarg for his comments and suggestions, to Laura Fejerman from UCSF for clarifications on genetic questions, and to Diego Comin and Marti Mestieri for sharing their results on the margins of technology diffusion. Gorodnichenko thanks the NSF, the Sloan Foundation, and the Hellman family fund for financial support. 


\section{Introduction}

One of the central questions in economics of growth and development is why disparities in income and development across countries are large and persistent. Despite decades of research, this question continues to puzzle the profession as the bulk of the difference is attributed to variation in productivity, a residual component not accounted by observed factors. It is widely perceived that the key conduit of economic growth and productivity enhancements is innovation that brings new goods and services to the economy as well as new ways to produce existing goods and services. In this paper, we argue that individualist culture plays a key role in stimulating innovations and hence in explaining long-run economic growth, alongside with other important factors such as institutions and human capital.

The idea that culture is a central ingredient of economic development goes back to at least Max Weber who, in his classical work "The Protestant Ethic and the Spirit of Capitalism," argued that the protestant ethic of Calvinism was a very powerful force behind the development of capitalism in its early phases. Weber saw culture as the driving force behind differences in economic development. His theory was in direct opposition to Karl Marx's thesis that culture is determined by the level of economic development and by the economic interests of the various social classes. Although Landes (1998) and others have argued that culture played a fundamental role in explaining the wealth of nations, and the literature on the economic effects of culture is growing fast, there has so far been little systematic work examining theoretically and empirically the effect of culture on long-run growth and development.

To be clear, we define culture as the set of values and beliefs people have about how the world (both nature and society) works as well as the norms of behavior derived from that set of values. This definition highlights that culture affects not only social norms but also economic behavior such as the propensity to save or to innovate and many other economic decisions such as fertility choices, investment in education, charitable contributions or the willingness to contribute to public goods. Culture is directly related to institutions, broadly defined, in the sense that culture, like formal political or legal institutions as defined by North (1990), imposes constraints on individual behavior.

In our analysis in this paper, we focus on only one dimension of culture that may be relevant for long-run growth: individualism versus collectivism. ${ }^{1}$ Individualism is a cultural trait that emphasizes personal freedom and achievement. Individualist culture therefore awards social status to personal accomplishments such as important discoveries, innovations, great artistic or humanitarian achievements and all actions that make an individual stand out. In contrast, collectivism emphasizes embeddedness of individuals in a larger group. It encourages conformity to a group, loyalty and respect to one's superiors,

\footnotetext{
${ }^{1}$ In Gorodnichenko and Roland (2011), we examine other cultural dimensions.
} 
and discourages individuals from dissenting and standing out. ${ }^{2}$ Although one may obviously contemplate other cultural aspects, the individualism-collectivism distinction is considered by cross-cultural psychologists to be the main dimension of cultural variation (see Heine, 2007) and it has potentially important economic effects. For example, Greif $(1994,2006)$ uses this distinction in his path-breaking work showing strong effects of culture on economic outcomes.

Several main elements of the difference between individualism and collectivism play a role in our theory. Because individualism emphasizes personal freedom and achievement, it awards social status to personal accomplishments such as important innovations. On the other hand, individualism can make collective action more difficult because individuals pursue their own interest without internalizing collective interests. Collectivism makes collective action easier in the sense that individuals internalize group interests to a greater degree. However, it also encourages conformity and discourages individuals from dissenting and standing out. This framework implies that individualism should encourage innovation more, everything else equal, but collectivism should have an advantage in coordinating production processes and in various forms of collective action. ${ }^{3}$ Despite this trade-off, we argue that the advantage of individualism has a dynamic effect, whereas the advantage of collectivism has only a static effect. As a result, the advantage of individualism in innovation dominates over longer horizons, thus giving individualistic culture an edge in long-run economic growth.

We bring the argument to the data by testing the effect of individualism versus collectivism on longrun growth. Ideally, we would like to have a reliable measure of individualism from centuries ago to see how cultural differences of the past affected long-run growth. Unfortunately, our measure of individualism is from the second half of the twentieth century and exists only as a cross-sectional variable. In principle, this is not necessarily damning for our research if culture changes slowly. Nevertheless, this mistiming in the measurement of culture raises several concerns. In particular, our measure of culture might be endogenous to economic outcomes. Therefore, finding a convincing causal effect of culture on long-run growth would require a valid instrumental variable (IV). It is extremely difficult to find foolproof instrumental variables for cross-country regressions. We have nevertheless come up with several instrumental variables that are jointly strongly suggestive of a possible causal link from individualism to long-run growth. For the first set of instrumental variables, we use information on prevalence of certain genes in a population (the frequency of the S-allele in the serotonin transporter gene 5HTTLPR making people more prone to depression when

\footnotetext{
${ }^{2}$ Platteau (2000) illustrates collectivist culture in the context of African development. Specifically, he documents that productive individuals are seen with suspicion and are coaxed into sharing their surplus with the community. Collective punishments exist to penalize the rich. They take the form of social ostracism, loss of status, or even violence. Behind these punishments is the fear that the community's cohesiveness will be undermined and that an individual who proves more successful will leave the village or will not redistribute any surplus food or production.

${ }^{3}$ There might also be an advantage of collectivism in terms of public good provision. We do not explore this aspect in this paper.
} 
confronted with stressful events and the frequency of the $\mathrm{G}$ allele in polymorphism A118G in $\mu$-opoid receptor gene creating a stronger psychological pain from social exclusion) as well as historical pathogen prevalence in a particular geographical area. According to recent advances in genetics and psychology, the genetic variables appear to directly affect personality traits and can explain the prevalence of collectivist culture in certain populations. In a similar spirit, strong prevalence of pathogens can incline populations to adopt a collectivist culture. Chiao and Blizinsky (2009), Way and Liebermann (2010) and others argue that communities with a higher frequency of these two genes and with a higher pathogen prevalence developed social norms to adapt to this genetic and epidemiological environment. These data are good candidates for instrumental variables, and they can be argued to satisfy the exclusion restriction. Specifically, the two genetic variables are not plausibly correlated to income per capita through any other channel than collectivism. One might think that historical pathogen prevalence affected income per capita via health, but health variables that may or may not affect income (e.g., life expectancy) are not significantly correlated with historical pathogen prevalence. Unfortunately, cross-country coverage is limited to approximately 40 countries for the two genetic variables, which are the cleanest instrumental variables one can currently obtain in this kind of work.

Another instrumental variable that is more widely available worldwide is a measure of genetic distance between the population in a given country and the population in the United Kingdom, which is the second most individualistic country in our sample. ${ }^{4}$ A large literature studying values of descendants of immigrants as a function of the country of origin (see Fernandez, 2010, for a survey) documents that parental transmission of culture is a fundamental determinant of the cultural values of individuals. Obviously, parents transmit their cultural values as well as their genes to their offspring. Populations that interbreed a lot should be genetically and culturally close because a similar parental transmission mechanism is at work in both cases. Therefore, measures of genetic distance can be seen as a proxy measure of differences in cultural values. In this case, when we use genetic distance as an instrumental variable, we do not postulate a causal relationship between genes and cultural attributes such as individualism. We simply exploit the correlation between genetic distance and cultural differences across populations as both genes and culture are transmitted from parents to offspring. Since there are no identified direct genetic causes for why some countries became wealthier than others, genetic distance is very likely to satisfy the exclusion restriction. Furthermore, we use only "neutral" genetic markers that have no direct effect on fitness (i.e., ability to think, run, work, etc.) and thus economic or cultural outcomes. These neutral genetic markers are very unlikely to be affected by economic outcomes, and thus we can exclude reverse causality in our instrumental variable estimates. We use genetic distance based on frequencies of blood types, which is the genetic information available for the

\footnotetext{
${ }^{4}$ The U.S. is the most individualist country but is culturally less homogeneous than the U.K. We find similar results when we use the U.S. as the origin for calculating genetic distance.
} 
largest number of countries. ${ }^{5}$ A potential drawback of genetic distance is that there could be channels other than individualism through which genetic distance can be indirectly related to long-run growth (e.g., another cultural dimension). Because it is more difficult to argue a priori that genetic distance satisfies the exclusion restriction, we combine this variable with the other instrumental variables mentioned above and apply standard statistical tests for the exclusion restriction. Our measure of genetic distance successfully passes these tests, and one can thus feel comfortable using it as instrumental variable for a set of countries larger than one can cover with the genetic variables mentioned above.

Conditional on the quality of our instrumental variables, our econometric results suggest a statistically and economically significant effect of individualism on income per worker. According to some of our estimates, a one standard deviation increase in the individualism score nearly doubles income per worker Our results are robust to the introduction of different types of controls and different measures of long-run growth as well as to using dyadic regressions or alternative instrumental variables based on linguistic properties of individualist cultures. Although our estimates are based on cross-country variation, these estimates are also remarkably consistent with regional variation within countries like Italy where there exists considerable cultural variation across regions. In addition, the effects of individualism on total factor productivity and innovation are also very strong, thus suggesting that individualism pushes the technological frontier and thus that the effects we estimate capture more than simple technological diffusion.

To rule out alternative explanations for differences in economic development and to isolate the effect of individualism on economic development from the alternative channels, we employ a battery of checks and tests. First, we explore how our results vary across subsamples of countries that were differentially exposed to these alternative channels. For example, we report results estimated on a sample of African, Asian or European countries to exclude the possibility that our results are influenced by including countries in Americas and Oceania where colonization by European settlers was particularly important. We find that our results are remarkably consistent across subsamples based on continents (e.g., Asia vs. Europe) or levels of development (e.g., OECD vs. non-OECD economies). We also take into account migrations that have taken place between countries over the last 500 years, exploiting the Putterman and Weil (2010) data, and our results hold if we restrict our sample to countries having roughly the same ethnic composition as 500 years ago.

Second, we introduce controls for alternative determinants of economic development and examine how our estimates of individualism's effects vary with the inclusion of these additional controls. For example,

\footnotetext{
${ }^{5}$ Genetic distance data have been used by Guiso et al. (2009) and by Spolaore and Wacziarg (2009) in contexts that are close but different in various respects from the setting of our paper. Their data includes a broader set of genes but only for 42 ethnicities across the world. Guiso et al. (2009) interpret genetic distance as proxying both cultural and genetic dissimilarity which is a source of a potential bias distorting people's propensity to trust each other and engage in trade. Spolaore and Wacziarg (2009) view genetic distance as a barrier to the diffusion of technologies as people that are more distant from each other will communicate less and thus benefit less from technological innovation.
} 
we may find strong effects of individualism on economic outcomes because individualism can be correlated with the quality of institutions (e.g., Hall and Jones, 1999, Acemoglu et al., 2001), human capital (e.g., Barro and Lee 2001), legal origin (e.g., La Porta et al. 2008), ethnic fractionalization (e.g., Fearon 2003), speed of technology diffusion (e.g., Spolaore and Wacziarg, 2009, Fogli and Veldkamp, 2012), and remoteness from Europe (e.g., Redding and Venables 2004) - key variables that have been shown to be correlated with economic outcomes we want to explain. We document that controlling for these additional factors does not change our conclusions that individualism explains a significant fraction of variation in economic development. Furthermore, we find that individualism and income per capita continue to be strongly related even in dyadic regressions where we can control for country fixed effects thereby ruling out explanations based on a large class of potentially relevant but omitted variables. Thus, individualism has an effect on economic development that is independent of institutions and of other commonly suggested factors, and our estimates are not driven by any omitted variable bias we could think of.

In light of these findings, we also examine the interactions between individualism and institutionsmeasured by the average protection against expropriation risk as in Acemoglu et al. (2001) — using our instrumental variables for individualism and the Acemoglu et al. (2001) settler mortality instrument for institutions. We cannot exclude a two-way interaction, culture affecting institutions and institutions affecting culture. However, when using settler mortality data constructed by Albouy (2012), we find that the link from institutions to culture is much weaker and loses robust significance. This result is consistent with Roland (2004) who argues that culture tends to change more slowly than political or legal institutions and, therefore, might have an important effect on the choice of political and legal institutions itself.

Third, we examine within-country variation of occupational choices across ethnic groups so that we can further minimize the effects of potentially omitted factors in our cross-country regressions. In particular, our theory predicts that persons from ethnic groups that are characterized as more individualistic should enroll in research oriented occupations, which require independent thinking and deviation from conventional ways of doing things, more frequently than persons raised in the traditions of more collectivist cultures. Using U.S. Census data, we find support for this prediction: people from more individualistic cultures are more likely to become scientists and researchers.

In short, we examine many other potential channels suggested in the previous literature via which genetic distance might indirectly affect economic outcomes. We find that individualism is still positively related to innovation and long-run growth after controlling for these other potential explanations. While we cannot rule out the possibility of an omitted variable driving both individualism and economic development, one may find it increasingly difficult to propose a plausible, quantitatively important alternative that we did not attempt to control for in our empirical analysis. Together with the evidence, based on cross-cultural psychology, on the effects of the distribution of genetic endowments on collectivist 
culture, these results show that individualism is empirically relevant for understanding economic development and should be included in theories of economic growth.

Our findings contribute to the nascent literature emphasizing the effects of culture on economic outcomes (see Spolaore and Wacziarg (2013) for a review). Greif $(1994,2006)$ modeled the effects of individualist versus collectivist beliefs on contract formation, social stratification and the expansion of markets in the late Medieval trade in the Mediterranean. Bisin and Verdier $(2000,2001)$ examined the dynamics of intergenerational transmission of cultural preferences taking into account family choices of cultural transmission and effects of social environment. Fernandez (2013) modeled cultural change as Bayesian learning in the context of changes in attitudes towards labor force participation. Tabellini (2008b, 2010) studied how the cultural transmission of values of cooperation can affect the form of institutions, which in turn reinforces norms of cooperative behavior. Ashraf and Galor (2007) model the trade-off between non-conformism and conformism at different stages of development and provide a theory of why China was richer in the Malthusian stage of development but lagged behind in the industrialization stage. Doepke and Zilibotti (2008) developed a model to explain the cultural transmission of the values of the preindustrial middle class (thriftiness, hard work) in the industrialization process as well as their eventual social success and the demise of the landed aristocracy while Corneo and Jeanne (2010) argue that cultural transmission can result in poverty traps. In subsequent work, Doepke and Zilibotti (2013) show how in entrepreneurial societies, innovation and risk-taking create incentives for cultural transmission of values of thrift and risk-taking, which in turn sustain a high level of entrepreneurship and innovation. Fernandez, Fogli and Olivetti (2004), Fernandez and Fogli (2009) and Giuliano (2007) examined the effects of culture on fertility choices, family living arrangements and labor supply decisions. Barro and McCleary (2003) argue that economic growth is affected by religious beliefs (e.g., existence of hell and heaven). Knack and Keefer (1997) considered the effect of social capital on economic performance. Aghion et al. (2010) found a negative correlation between trust and the level of regulation in societies. Guiso et al. $(2003,2009)$ examined the effect of trust on economic attitudes and international trade patterns, and Giuliano et al. (2014) investigated the link between geography, genetic distance, transportation costs and economic variables. Tabellini (2008a) and Licht et al. (2007) provide evidence consistent with a causal link from culture to institutions and Jellema (2009) provides evidence consistent with a causal link from cultural practices to a society's basic achievements (such as the presence of writing, the wheel or money) documented for different cultures in Murdock's (1967) Ethnographic Atlas. In line with Roland (2004), Murrell and Schmidt (2011) show that in seventeenth century England cultural change preceded the important institutional changes brought about by the Glorious Revolution of 1688 .

The rest of the paper is organized as follows. Section 2 presents our argument for how individualism and economic growth can be related. In section 3, we discuss the data used in our empirical analysis. Section 
4 contains our empirical analysis of how individualism can affect economic development. Sections 5 and 6 examine the interplay between individualism, institutions and other factors. In Section 7, we investigate occupational choices of various ethnic groups in the USA. Section 8 makes concluding remarks.

\section{The economic argument}

In this section, we synthesize how individualism/collectivism can affect long-term growth and development via innovation and production. Our discussion is intentionally narrative to formulate the argument in general terms (we relegate to Appendix A a simple endogenous growth model, which we find useful in making our argument precise, and in particular in differentiating static and dynamic effects of culture). Hence, we focus on general themes documented by previous studies in sociology, economics, history, case studies in the business management literature, etc.

While there is a general agreement that technological innovations are the central conduits of economic growth and development, a central question is how innovation is stimulated. Obviously, monetary rewards from patents, market power, etc. provide strong incentives for innovation. However, there are other important dimensions such as social status that can also compensate innovators for their efforts. Our main hypothesis is that individualistic societies permit and encourage more innovation than collectivist societies by providing a higher social status for individuals making important discoveries. There is ample evidence (e.g. Merton 1973) that social reward with heightened status is the most significant part of the total reward for scientists. Indeed, many probably have dreamed of becoming the first to discover a new element, a new law or a new technology. By stimulating more innovations, individualism gives a dynamic advantage that can lead to higher economic growth. In contrast, collectivist societies emphasize the role of collective effort and give less social status reward to innovation. They reward conformity more and discourage individuals from dissenting (see e.g. Bond and Smith, 1996).

High status rewards can counteract the disincentive effects of high tax rates because while income and wealth can be expropriated, social status cannot. Thus even if a country has bad institutions with high expropriation risk, there can still be incentives to innovate if there is a high enough status reward to innovation. Clark (2007) argues against the view that institutions are important for long-run growth by pointing to the fact that institutions in England around the time of the Industrial Revolution were no better than in many developing countries today, whose institutional weaknesses are precisely cited as the main cause of their underdevelopment. Bringing individualist culture in the picture, which has been shown by historians to exist in England at least since the thirteenth century (Macfarlane, 1978), the negative effect of predatory institutions on long-run growth can be offset by the social status reward to innovation that is present under an individualist culture.

The comparative advantage of collectivist societies is hypothesized instead to be on the production side, which almost always involves combining inputs and hence requires coordination of workers/units. 
Such coordination is easier to achieve in collectivist cultures that value harmony, conformity and team effort. For example, Liker (2003) documents that teamwork and consensus building are among defining features of the Japanese way to run business. Efforts to copy the Japanese organization inside U.S. automobile factories however failed in their attempts to catch up with the efficiency of Japanese automobile firms, since American carmakers could replicate lean production but could not imitate Toyota's culture. Because enhancing an assembly line by improved coordination is likely to run into diminishing returns, the production advantage of collectivism is static and may be interpreted as a level effect.

In addition, while the vast majority of fundamental innovations were made in the U.S. and Western Europe (see for example Harrison, 2004), which have a highly individualistic culture, collectivist countries may be good at incremental innovations. For example, the color TV was invented by RCA, an American firm, but Japan ended up making the best TV sets. Sony invented the walkman which was a great consumer success starting in the 1980s. However, the key invention of the compact cassette was made by Philips, a European firm. Similarly, Sony introduced the VCR but the technology was invented by Ampex, an American firm which was unable to make its VCR affordable to households. One can argue that incremental innovations have diminishing returns (i.e., one can relatively easily improve a cassette player in terms of design and functionality but one needs a radical innovation to create a CD player) and gains from incremental innovations are limited in the long run and, hence, the technological frontier is likely to be pushed by the individualistic societies. Collectivist societies may be able to close some of the gap in technology via the international diffusion of technology, an element that we do not incorporate in our model. However, it is important to acknowledge that this diffusion is a gradual process: growth theories analyzing the diffusion of development emphasize that the tacit and idiosyncratic nature of technological knowledge make it impossible to transplant new technologies costlessly and immediately to other countries. In practice, investments are needed to master an existing technology and adapt it to local conditions (see Aghion and Howitt, 2009, Jones, 2002, Evenson and Westphal, 1995, Grossman and Helpman, 1991). If diffusion of technology from leaders to laggards is gradual, one should thus observe a stationary distribution of income differences with leaders (more individualist and hence more innovative countries) being richer since they are technologically a few steps ahead of laggards. ${ }^{6,7}$

This reasoning can shed new light on episodes of "reversal of fortune". In the Malthusian stage when labor is allocated almost exclusively to production of final goods (food, clothes, etc.) and virtually no

\footnotetext{
${ }^{6}$ One could think of setups where collectivism might affect not only the static output level but also long-run growth. For example, in a collectivist culture there might be better public good provision which could be complementary to private innovation. We are not aware of evidence to support this claim.

${ }^{7}$ Using information on the behavior of foreign firms operating in China, Huang et al. (2013) compare foreign firms owned by ethnic Chinese and firms owned by individuals who are not ethnic Chinese. Huang et al. find that firms run by ethnic Chinese have an initial advantage operating in China but they also have a dynamic disadvantage because they invest less in technology and human capital than firms owned by non-Chinese. These results are consistent with our theory if firms owned by non-Chinese are from more individualistic cultures.
} 
labor is allocated to innovation, collectivist societies, which enjoy a greater level of coordination, may be richer than individualistic societies. This prediction is consistent with, for example, China being richer, more urbanized and more densely populated than much of Western Europe in 1500. However, as the economy exits the Malthusian stage (e.g. after the Black Plague), the collectivism-individualism difference across cultures starts to play a new and different role. Since individualistic societies grow faster than collectivist societies outside the Malthusian stage, countries with an individualistic culture eventually become richer and thus one may observe a "reversal of fortune", i.e. those countries catch up and become more affluent than collectivist countries that initially had a higher level of development.

In summary, there is a trade-off between the benefits and costs of individualism and collectivism. Our overview suggests that the benefits of individualism affect the output growth rate while the costs of individualism affect the level of output. In the long-run, the latter effect, which is dynamic, should thus dominate the former effect, which is static. Hence, despite the short-run trade-off, countries with a more individualistic culture should unambiguously grow faster and eventually enjoy a higher level of output. In what follows, our objective is to explore empirically whether cultural attributes such as individualism/collectivism are strong predictors of incomes, productivity and innovation.

\section{Data}

A key question for our empirical analysis is how to measure individualism. A well-known measure of individualism (and other cultural dimensions) at the country level was developed by Hofstede (2001) who initially used surveys of IBM employees in about 30 countries. To avoid cultural biases in the way questions are framed, the translation of the survey into local languages was done by a team of English and local language speakers. With new waves of surveys and replication studies, Hofstede's measure of individualism has been expanded to 96 countries. ${ }^{8}$ In a nutshell, the individualism score measures the extent to which it is believed that individuals are supposed to take care of themselves as opposed to being strongly integrated and loyal to a cohesive group. Individuals in countries with a high level of the index value personal freedom and status, while individuals in countries with a low level of the index value harmony and conformity. Hofstede's index as well as the measures of individualism from other studies use a broad array of survey questions to establish cultural values. Factor analysis is used to summarize data and construct indices. In Hofstede's analysis, the index of individualism is the first factor in work goal questions about the value of personal time, freedom, interesting and fulfilling work, etc. This component loads positively on valuing individual freedom, opportunity, achievement, advancement, recognition and negatively on valuing harmony, cooperation, relations with superiors. ${ }^{9}$ This index measures quite well the notion of individualism given above. Similarly, the emphasis on harmony, cooperation and good relations with superiors fits well with the notion of

\footnotetext{
${ }^{8}$ The most current version of the data is available at http://www.geert-hofstede.com/.

${ }^{9}$ Appendix C provides the list of questions. See Hofstede (2001) for more details.
} 
collectivism given above and strongly suggests greater capacity at coordination within the group but also a stronger sense of conformity and a fear of sticking out. Although Hofstede's data were initially collected mostly with the purpose of understanding differences in IBM's corporate culture, the main advantage of Hofstede's measure of individualism is that it has been validated in a number of studies. ${ }^{10}$ For example, across various studies and measures of individualism (see Hofstede (2001) for a review) the United Kingdom, the USA and Netherlands are consistently among the most individualistic countries, while Pakistan, Nigeria and Peru are among the most collectivist. Figure 1 represents a world map of Hofstede's individualism scores.

The causality between individualism and economic outcomes can a priori flow in both directions. For example, as we have argued above, more individualist countries may be wealthier because individualism fosters innovation. On the other hand, one might reason that a more affluent economy can support a more individualist culture. Indeed, there is a long tradition in social sciences starting with Marx claiming that economic development affects a country's culture.

To address this potential endogeneity problem, we use a number of instrumental variables. We first use genetic and epidemiological data which the recent literature in cross-cultural psychology has directly linked to collectivism. A first set of data is from Chiao and Blizinsky (2009) who document a strong correlation between collectivism and the presence of a short (S) allele in the polymorphism 5-HTTLPR of the serotonin transporter gene SLC6A4. This allele is known in psychology to put individuals at greater risk for depression when exposed to life stressors. The mechanism linking individual genetic traits and culture is that a collectivist culture protects individuals from these stressors by embedding them more strongly in communities with strong social links thus providing strong psychological support networks. These data are complemented with data assembled in Inglehart et al. (2014) for a total of 43 countries. We also use data from Way and Liebermann (2010) showing that collectivism is also strongly correlated with the $G$ allele in polymorphism A118G in the $\mu$-opoid receptor gene that leads to higher stress in case of social rejection. Way and Liebermann (2010) also reason that collectivist culture can be seen as providing psychological protection from social rejection. These data are complemented by various other sources (see Appendix F) for a total of 34 countries. Finally, we use epidemiological data put together by Murray and Schaller (2010) for 96 countries on pathogen prevalence, complementing earlier work by Fincher et al. (2008). ${ }^{11}$ Given a strong correlation between pathogen prevalence and collectivism, Fincher et al. and Murray and Schaller argue that

\footnotetext{
${ }^{10}$ See for example Hoppe's (1990) study among members of parliaments, labor and employer leaders, academics and artists in 18 countries, Shane's (1995) study across 28 countries for international companies other than IBM, Merrit's (2000) study on commercial airline pilots in 19 countries, de Mooij's (2003) survey among consumers in 15 European countries and van Nimwegen's (2002) research among employees of ABN-AMRO bank in 19 countries. In Appendix E, we use an alternative data base established by cross-cultural psychologist Shalom Schwartz, built with the purpose of establishing a core set of values that have a common cross-cultural meaning. Schwartz $(1994,2006)$ gathered survey responses from K-12 schoolteachers and college students for a total of 195 samples drawn from 78 nations and 70 cultural groups between 1998 and 2000. We find similar results.

${ }^{11}$ Murray and Schaller (2010) use 9 pathogens: leishmanias, trypanosomes, malaria, schistosomes, filariae, leprosy, dengue, typhus and tuberculosis.
} 
stronger pathogen prevalence pushed communities to adopt more collectivist values emphasizing tradition, putting stronger limits on individual behavior, and showing less openness towards foreigners. Collectivism is thus understood as a defense mechanism created to cope with greater pathogen prevalence.

We then combine each of these instrumental variables with a measure of genetic distance between people in different countries and perform statistical tests of overidentification to check whether genetic distance meets the exclusion restriction. To the extent that culture is transmitted mainly from parents to children, so are genes. Thus, genetic markers can be used as a proxy for cultural markers and this instrumental variable should be seen as a proxy measure of cultural transmission. To be clear, we do not postulate a causal effect between genetic distance and cultural distance. Instead, we exploit the correlation between cultural and genetic transmission from patents to offspring. Since economic development is unlikely to affect genetic pools in a matter of a few centuries, one can reasonably expect that genetic distance is a good IV for differences in cultural attributes. These genetic data originate from Cavalli-Sforza et al. (1994) which provides measured genetic markers for roughly 2,000 groups of population across the globe. These data contain allele frequencies (alleles are variants taken by a gene) for various ethnic groups. Since we want to eliminate the feedback from economic outcomes to genetic variation, we focus on neutral genetic markers that are not related to evolutionary fitness, and thus economic performance. Furthermore, as discussed in CavalliSforza et al. (1994), genetic variation for countries not affected by massive colonization since 1500s was largely determined during the Neolithic migration of early humans thousands of years ago. ${ }^{12}$ We use the Mahalanobis distance between the frequency of blood types in a given country and the frequency of blood types in the UK, which is the second most individualistic country in our sample. ${ }^{13}$ The geographical distribution of the Mahalanobis distance measure is displayed in Figure $2 .{ }^{14}$ Using the frequency of blood types is attractive because, apart from being neutral genetic markers (i.e., different blood types do not cause a higher level of intelligence, output or individualism), the frequency of alleles determining blood types is the most widely available genetic information and thus we can construct the most comprehensive (in terms of

\footnotetext{
${ }^{12}$ Note that the genetic and cultural data were collected predominantly in 1950s through the early 1970s. On the other hand, our measures of economic outcomes are generally from the $21^{\text {st }}$ century. This difference in the timing of explanatory/instrumental variables (i.e., culture and genetic variables) and dependent variables (i.e., economic outcomes) helps us to alleviate certain types of endogeneity (e.g., recent strong migration of skilled workers).

${ }^{13}$ The advantage of using distance relative to the U.K. is that U.K.'s population is genetically more homogenous than the population in the U.S.A. - the most individualistic in the world - and that the U.K. is often described as the cradle of individualism and the Industrial revolution. Indeed, the share of indigenous (as of year 1500) population in modern U.K. is over 94 percent. Results are very similar when we use distance to the U.S.A. Note also that we get similar results when we use the distance to the most collectivist countries (Guatemala, Pakistan, Mozambique, Tanzania, etc.). ${ }^{14}$ The Mahalanobis distance between a vector $x$ and $y$ picked from distributions $X$ is

$$
d_{M}(x, y)=\left((x-y)^{\prime} \Sigma_{X}^{-1}(x-y)\right)^{1 / 2}
$$

where $\Sigma_{X}$ is the covariance matrix for $X$. In our contexts, $\Sigma_{X}=\operatorname{var}\left(\left[\bar{f}_{A, c} \bar{f}_{B, c}\right]\right)$ where $A$ and $B$ denote blood types and $c$ indexes countries. We obtain the Euclidian distance $d_{E}(x, y)$ when $\Sigma_{X}$ is set to the identity matrix. Thus, the Euclidian distance between country $c$ and the USA is equal to $d_{E}(c, U S A)=\left\{\left(\bar{f}_{A, U S A}-\bar{f}_{A, c}\right)^{2}+\left(\bar{f}_{B, U S A}-\bar{f}_{B, c}\right)^{2}\right\}^{1 / 2}$.
} 
country coverage) measure of genetic distance. ${ }^{15}$ Another key advantage of utilizing frequency of blood types is that we can exploit alternative sources of information (e.g., Red Cross) about frequency of blood types to corroborate our data from DNA studies. In a series of robustness checks, we also employ aggregate measures of genetic distance constructed in Cavalli-Sforza et al. (1994) and used in Spolaore and Wacziarg (2009). ${ }^{16}$

Since the genetic data are available at the level of ethnic groups while our analysis is done at the country level, we aggregate genetic information using ethnic shares of population from Fearon (2003). ${ }^{17}$ Specifically, if we define blood frequency $f_{b e c}$ for blood type $b$ and ethnic group $e$ in country $c$, then the country level blood frequency for type $b$ is calculated as $\bar{f}_{b c}=\sum_{e} s_{e c} f_{b e c}$ where $s_{e c}$ is the share of ethnic group $e$ in the population of country $c .{ }^{18}$ In a robustness check, we also employ an instrumental variable based on linguistic peculiarities of individualistic cultures. Specifically, in languages where the pronoun cannot be dropped in a sentence there is a greater differentiation between the individual (first person of the singular) and the community, whereas in languages where pronouns can be dropped there is less emphasis on such a differentiation. Kashima and Kashima (1998) and others document that prohibition of pronoun drop is strongly correlated with individualism. ${ }^{19}$ This instrumental variable was used in Licht et al. (2007), Tabellini (2008a) and other papers studying the effects of culture on socioeconomic outcomes.

The sources of data on economic outcomes are standard. We take income per worker data in 2000 from the Penn World Tables (version 6.3). To control for differences in factor endowments, we use data on total factor productivity (TFP) from Hall and Jones (1999) and Jones and Romer (2010). These two measures have been widely used as measures of long-run growth in the literature.

Since the main conduit of individualism's effect on growth in our argument is innovation, we proxy for the intensity of innovations with the innovation performance index and the log patents per million population from Economist Intelligence Unit (2007, 2009; henceforth EIU). EIU constructs patents per million population as the sum of patents granted to applicants (by residence) from the 82 economies by three major government patent offices - the European Patent Office, the Japanese Patent Office, and the US Patent and Trademark Office. The data are averaged over 2002-2007. Although the use of patent data has a

${ }^{15}$ Note that blood types are not known to be correlated with alleles that affect evolutionary fitness. In genetics, such correlation, or non-random association between alleles is called "linkage disequilibrium". Random formation of haplotypes (groups of alleles) is generally assumed in genetics but the study of linkage disequilibrium has been expanding in recent years. See e.g. Pritchard and Przeworski (2001).

${ }^{16}$ Spolaore and Wacziarg (2009) use genetic information for 42 ethnic groups while we use the full spectrum of genetic information for 2,000 groups. We complement genetic information from Cavalli-Sforza et al. (1994) with Mourant et al. (1976) and Tills et al. (1983).

${ }^{17}$ Whenever Fearon's (2003) data were too crude, we used additional sources of information. For example, Fearon (2003) reports on the share of whites in the USA. We used a variety of sources about migration patterns and information on ancestors to split whites into British, German, Italian, Polish, etc. Details are available upon request.

${ }^{18}$ Because Hofstede's analysis involved matching employees with similar jobs inside IBM across different countries, the ethnic composition of the samples could have deviated the composition of the countries' population. Unfortunately, information about the ethnic composition of the samples is not available and thus we cannot correct this potential issue using e.g. re-weighting.

${ }^{19}$ For example, English does not allow dropping pronouns and it is the only language which capitalizes "I". 
number of problems, this is the single best available measure for innovation outputs. The innovation performance index incorporates information on patents and alternative indicators of innovation output such as royalty and license fee receipts as a percentage of GDP, high-technology manufacturing output per head, high-technology services output per head, the number of citations from scientific and technical journals, etc. As documented in EIU (2007, 2009), these measures are highly correlated with other proxies for innovation performance such as UNIDO estimates of the share of medium- and high-technology products in a country's manufacturing output and its manufacturing exports, and the results of a survey question from the World Economic Forum's Global Competitiveness Report that asked respondents to rate the extent to which companies were adept at, or able to absorb, new technology. Thus, these measures of innovation are likely to capture salient features of innovative activities across countries.

The timing of data collection is different across variables (see Appendix G). For example, while frequencies of blood types were collected in the 1940s and 1950s, other genetic data that we use were collected recently. The first individualism scores were constructed in the 1960s for a limited number of countries and the coverage increased gradually since then. Data on historic pathogen prevalence refer to early-to-mid $20^{\text {th }}$ century, before the epidemiological revolution. Outcome variables such as output per worker, patents per capita, total factor productivity are generally available for recent years. Ideally, one would like to have measures of our cultural variable (individualism) and of instrumental variables such as pathogen prevalence before the Industrial Revolution to correctly estimate the effect of individualism on long-run growth centuries later. Unfortunately, such data are not available. Nevertheless, we think that, the quantitative significance of this mistiming is not likely to be large. First, the central premise of our argument (as is also demonstrated by a large body of research) is that culture is slow-moving so that culture "today" in a given country is similar to what it was in the past, even after centuries of economic development. Second, to strengthen the argument and minimize possible endogeneity of individualism scores, we use genetics-based instrumental variables that are unlikely to change materially since the Malthusian stage. This significantly strengthens our research design. In addition, as we discuss below, the plausible correlation structure of errors is such that our estimates could understate the strength of the relationship between individualism and the outcome variables. Third, historic pathogen prevalence data were constructed for the era preceding the revolution in the medical treatment of malaria, typhus, tuberculosis and other major contagious diseases. Hence, this measure is likely to provide a good proxy of pathogen prevalence for earlier periods.

\section{Baseline econometric specification and results}

Our argument predicts that more individualistic countries should be more affluent since individualism encourages innovation. Consistent with this prediction, Figure 3 shows that countries with more individualistic cultures enjoy higher levels of income, TFP and rates of innovation. Also, innovation is 
strongly positively correlated with income and TFP (Figure 4). These raw correlations, some of which were reported earlier in Hofstede (2001), are informative but they do not control for other factors and cannot be interpreted as causal relationships. ${ }^{20}$

To address these concerns, we employ the following basic econometric specification:

$$
Y_{i}=\alpha I N D_{i}+\beta X_{i}+e_{i}
$$

where $i$ indexes countries, $Y_{i}$ measures an economic outcome (e.g., log income per worker), $I N D_{i}$ is a measure of individualism, $X_{i}$ is a vector of control variables and $e_{i}$ is the error term. ${ }^{21}$ The vector $X_{i}$ includes commonly used controls for geography such as countries' longitude and latitude, a dummy variable for being landlocked, and a set of dummy variables for continents. In addition to this standard set of geographic controls, we include the percentages of population practicing major religions from Barro and McCleary (2003) to ensure that our results are not driven by differences in the composition of people following various religions.

As discussed above, we use several instrumental variables to deal with reverse causality in equation (1). Figure 5 shows that countries with more individualistic cultures are genetically less distant from the U.K. The converse applies to countries with collectivist cultures. At the same time, countries with individualist and collectivist cultures are genetically distant from each other. Note the strong negative correlation between genetic distance (computed relative to the U.K. which has the second most individualistic culture) and individualism.

Table 1 presents the OLS and IV estimates for the basic specification (1) where the dependent variable is log income per worker. In the basic OLS regression (column (1)), the coefficient on individualism is positive and significant. Specifically, a one standard deviation increase in individualism (say from the score of Venezuela to Greece, or from that of Brazil to Luxemburg) leads to a 66 percent increase in the level of income, which is a large effect. Taking the blood distance to the U.K. as instrument (column (2)) yields a somewhat larger estimate of the coefficient on individualism. In columns (3) and (4), the key instrument is the frequency of the short (S) allele in the polymorphism 5-HTTLPR of the serotonin transporter gene SLC6A4, which makes people more prone to depression when facing stressful events. In columns (5) and (6), the key instrument is the G allele in polymorphism A118G in the $\mu$-opoid receptor gene that leads to higher stress in case of social rejection. Finally, columns (7) and (8) use historical pathogen prevalence as an instrument. The first stages for all IV regressions (columns 2 to 8 ) are strong. By and large, the estimates are similar across the specifications.

\footnotetext{
${ }^{20}$ Note that Southeast Asian tiger economies have high innovation rates and a relatively low index of individualism. This might be explained by the fact that research effort in these countries was mostly directed and financed by the government rather than arising spontaneously.

${ }^{21}$ In light of the critique of regressions based on growth rates (see e.g. Easterly et al. (1993), Klenow and RodriguezClare (1997) and Hall and Jones (1999)), we focus on levels of income and other economic variables. In Appendix Table D2, we report results for growth rates over long periods (data constructed in Maddison (2003)).
} 
Note that when we include blood distance as a second instrumental variable (columns 4, 6 and 8), the estimated coefficient remains similar in magnitude to what one can obtain using instruments separately. Furthermore, the overidentifying restriction tests cannot reject the null of instrumental variables being correctly excluded at any standard significance level. The results of the overidentification test, together with the similar magnitudes of the coefficients, strongly suggest that blood distance picks up the link between genetic distance and cultural distance along the individualism-collectivism dimension. Spolaore and Wacziarg (2009) interpreted instead genetic distance as a proxy for barriers to the diffusion of knowledge. But how geographical distance — a prominent barrier to diffusion — affects individualism should not be systematically related to how e.g. a particular variation in the serotonin transporter gene SLC6A4 affects individualism. While our measure of blood distance might a priori reflect such barriers, the variation in SLC6A4 cannot be reasonably suspected of directly reflecting barriers to the diffusion of knowledge. If our measure of blood distance were to be interpreted as a measure of barriers in the diffusion of knowledge, then the coefficient on individualism in the second stage regression should be quite different when we use two instruments (blood distance and the other genetic/epidemiological variable) compared to when we use only one instrument (the other genetic/epidemiological variable). Indeed, if that were the case, these different instrumental variables would pick different aspects of the variation in individualism, thus leading to a different estimate and also to a rejection in the test of over-identifying restrictions. As we can see from Table 1, however, this is not the case. The results in Table 1 are thus consistent with both instrumental variables picking up approximately the same aspects of the variation in individualism, thus confirming our interpretation of blood distance as a proxy for cultural distance. These clarifications are important, because even if the instrumental variables used in columns 3 and 5 are much more directly related to individualism and collectivism, they are currently available only for respectively 43 and 34 countries. Given that our blood distance instrument covers many more countries and it passes the overidentification test in Table 1 despite its potentially lower plausibility as an instrument, for the rest of the paper we will use blood distance as an instrumental variable so that we can have additional robustness checks with more controls and subsamples as well as more statistical power to reach sharper conclusions.

Table 2 performs some first robustness checks. In row (1), we use as instrument for culture the Mahalanobis distance of frequency of blood types A and B in a country relative to the USA. In row (2), we use the frequency of blood types A and B separately so that we do not need to construct a distance measure to any particular country. In row (3), instead of using the Cavalli-Sforza et al. (1994) data on blood types, we use the data from the Red Cross. Although the Red Cross data are available for a much smaller set of countries, it does not require us to use ethnic shares in population to aggregate genetic data to the country level. In rows (4) and (5), we use the genetic distance data used by Spolaore and Wacziarg (2009). Their data also come from Cavalli-Sforza et al. (1994). In contrast to our blood distance, Spolaore and Wacziarg 
(2009) take genetic distances calculated by Cavalli-Sforza et al. (1994) for a larger set of genes. However, with a larger set of genes, the distance can be computed for only 42 ethnic subgroups of the world population. Similar to our approach, Spolaore and Wacziarg (2009) aggregate ethnic data to the country level using shares of ethnic groups in country populations. Row (6) uses the prohibition of pronoun drop as an instrument whereas in row (7), it is used as an instrument together with blood distance. In all cases, results are similar to the results we obtained for the baseline specification of Table 1 .

As an additional robustness check, rows (8)-(10) report results for a series of dyadic regressions that reduce the influence of using the U.K. as the comparison point for genetic distance. In particular, we estimate the following specification:

$$
\Delta_{i j}^{Y}=\alpha \Delta_{i j}^{I N D}+\beta X_{i j}+\sum_{k=1}^{N} \psi_{k} \times \mathbf{1}\{k=i\}+\sum_{k=1}^{N} \psi_{k} \times \mathbf{1}\{k=j\}+\text { error }
$$

where $\Delta_{i j}^{Y} \equiv \ln Y_{i}-\ln Y_{j}$ is the $\log$ difference in income per worker in country $i$ and country $j, \Delta_{i j}^{I N D}=$ $I N D_{i}-I N D_{j}$ is the difference between individualism scores in country $i$ and country $j, \mathbf{1}\{k=s\}$ is an indicator variable equal to one if $k=s$ and zero otherwise, $X_{i j}$ is a set of additional controls (if included). We instrument $\Delta_{i j}^{I N D}$ with the blood distance between countries $i$ and $j$. We find that the estimates of $\alpha$ continue to be highly significant and positive even after controlling for country fixed effects and geographical distance between countries. These last two results are important because country fixed effects control for other possible country-specific omitted variables, and controlling for geographical distance ensures that our results are not driven by factors related to diffusion of development.

In Table 3, we use different dependent variables, in line with our hypothesis that innovation is the channel through which cultural differences lead to differences in long-run growth. Panel A presents for comparison regressions with log income per worker as the dependent variable. The first four columns are OLS and the next four are IV regressions. In columns (2), (4), (6) and (8) we introduce continental dummies and in columns (3), (4), (7) and (8), we introduce geographical controls for landlocked countries, absolute values of country longitude and latitude and controls for the percentages of population practicing major religions in a country to make sure the effect of culture is not driven purely by religion. Panel B uses TFP from Hall and Jones (1999) as the dependent variable. We know indeed from their work that the main factor behind differences in incomes is variation in the level of TFP across countries. Panel C uses newer TFP data from Jones and Romer (2010). We find strong and positive effects of individualism on productivity. A one standard deviation increase in the individualism score leads to a 31 to 66 percent increase in TFP. Note that the effect on TFP is smaller than the effect on income. This should be expected since differences in income per worker are due to differences in factor accumulation on top of differences in TFP.

Finally, we perform a more direct test of our theory by regressing measures of innovation on individualism (Table 3, Panels D and E). With and without controls, we see a strong robust effect of individualism, confirming the channel going from individualism to innovation and to income and 
productivity. This finding is consistent with experimental evidence (e.g., Goncalo and Staw, 2006) showing that groups populated by individualistic persons generate more creative solutions to problems than groups populated by collectivist persons. Importantly, this finding also highlights that although countries may achieve a larger level of total factor productivity via diffusion of existing knowledge and willingness of people in individualistic cultures to accept new goods/services as well as new ways of producing goods/services, individualism affects the creation of knowledge. ${ }^{22}$ In other words, individualism not only helps countries to approach to the technological frontier, it also pushes the frontier.

To assess whether the magnitudes of individualism's effect on economic outcomes are plausible, consider differences in economic outcomes in Italy's South and North, which is a prime example of the importance of cultural effects. In his classic book, Putnam (1994) argues that the North of Italy is culturally similar to Switzerland and Germany (the individualism score for Switzerland is equal to 68) while the South of Italy is similar to Spain (the score is 51). Our baseline regression results (column (8) in Table 3, panels A and C) predict that the difference in income per capita and TFP between Italy's North and South should be $0.029 \times 17 \approx 49.3 \%$ and $0.018 \times 17 \approx 30.6 \%$ respectively. According to Italy's statistical office income per capita in Southern regions is about $50 \%$ smaller than income per capita in Northern regions. Using the methods developed in Hall and Jones (1999), Aiello and Scoppa (2000) estimate the difference in TFP across two regions to be $27 \%$. Thus predictions made from our cross-country regressions are remarkably similar to within-Italy variation in incomes and productivity and validate our parameter estimates. ${ }^{23}$

Note that China is not at all an outlier in our estimations. Despite its very fast growth for the last thirty years, China still remains relatively poor. Panel A of Figure 3 illustrates that China is approximately half a $\log$ point below the regression line so that China's income per worker would have to grow by more than 50 percent before it is on the regression line. Even if China's income per worker were as high as that of Mexico (approximately halfway between triple and quadruple of the actually observed income per worker in China), China would continue to look like a fairly typical data point in Panel A of Figure 3.

\section{Exploring other channels}

By focusing on the individualism/collectivism dimension, specification (1) does not include other potentially important determinants of economic development. To the extent these determinants are

\footnotetext{
${ }^{22}$ Fogli and Veldkamp (2012) document a positive relationship between individualism and the speed of diffusion of new technologies.

${ }^{23}$ When we do a similar exercise for Belgium assuming that Flanders has the individualism score of the Netherlands (80) and Wallonia has the individualism score of France (71), we predict a difference of GDP per capita of 26.1\% and a TFP difference of $16.2 \%$. Eurostat data from 2000 show a GDP per capita gap of $26.7 \%$ and a TFP gap of $9.4 \%$ (according to calculations by Jozef Konings). This is also remarkably close for a crude estimate. Note however that Brussels, which is French-speaking, has a GDP per capita twice that of Flanders which clearly shows that culture is only one factor in explaining income gaps.
} 
positively correlated with individualism, one may overstate the contribution of individualism to long-run growth. To address this concern about omitted variables, we explore in this section how controlling for these potentially important factors alters our conclusions.

A first major potential objection is that our results reflect migration patterns from the colonization era in which the Americas and Oceania were settled by European immigrants. One may also be concerned that our results are driven by a set of countries that for historical reasons were disadvantaged in economic development. If our theory explains income differences at the global scale, it is reasonable to expect our theory to explain income differences within continents where countries may be more similar. These concerns are important because, for example, Albouy (2012) argues that the theory of institutions as the fundamental cause of economic development has weak or no empirical support when tested within continents. Table 4 reports regression estimates for each continent separately and for OECD economies. ${ }^{24}$ By and large, we confirm our basic finding that individualism leads to higher income per worker. Even if we focus on OECD countries or relatively more developed countries in Europe and the Americas, individualism can explain a large fraction of variation in income. Although the coefficient on individualism is somewhat smaller for the subsample of developed countries, it does not necessarily mean that culture is less important. It simply reflects the fact that variation in incomes and individualism is more compressed in these countries and thus, with less variation in our key variables, measurement errors can have a stronger attenuation bias. This observation can also explain why the estimated coefficients are the largest for Africa where countries are extremely diverse in the level of development and individualism. For example, Morocco and Bhutan have individualism scores similar to those for Argentina and Spain, whereas Mozambique, Ghana, and Burkina Faso have some of the lowest scores in the world. Column (5) gives results for Africa, Europe and Asia where there was no massive migration of European settlers. Note that the coefficient in the IV estimation is even larger than in the results from Table 1 where the Americas and Oceania were included. In summary, our results are not driven by a particular continent and the effect of individualism is significant also within continents.

Another concern is related to migration flows that have happened over the centuries across countries in a continuous manner. For example, countries with bigger economic opportunities could have attracted migrants from places that also happened to have more individualistic cultures. To address this concern, we use the Putterman and Weil (2010) data on migration flows between 1500 and 2000. In column (1) of Table 5, we first replicate baseline OLS and IV regressions for our full sample. Then we restrict gradually the sample to those countries whose share of indigenous population as of 1500 in today's population is larger than respectively 80 percent (columns (3) and (4)), 90 percent (columns (5) and (6)), and 95 percent (columns (7) and (8)). We thereby eliminate countries that have witnessed large migration flows since 1500 . We find that

${ }^{24}$ Our estimate for OECD economies does not depend on any given country. For example, we find a similar estimate when we exclude Turkey. 
the coefficients remain highly significant as we restrict the sample and, if anything, the point estimates get larger. In summary, the results of Table 4 and 5 rule out the idea that our results reflect only migration patterns (most importantly, European settlers in the colonization period of the last 500 years) or the effects of being European (i.e., differences in individualism are not about Europe vs. the rest of the world).

A second major objection could be that individualism proxies for other forces of economic development. For example, a popular alternative explanation of economic development is the quality of institutions (see e.g. Acemoglu et al., 2001). Because cultural attributes and institutions are correlated and it is possible that culture simply captures the effect embodied in institutions, one needs to establish whether individualism has an effect separate from the effect of institutions. To differentiate effects of institutions and individualism, we augment the baseline econometric specification (1) with the average protection against expropriation risk between 1985 and 2009, a measure of institutions used by Acemoglu et al. (2001) and the majority of previous papers studying the effects of institutions on socioeconomic outcomes: ${ }^{25}$

$$
Y_{i}=\alpha I N D_{i}+\gamma I N S T_{i}+\beta X_{i}+e_{i}
$$

where $I N S T_{i}$ is a measure of institutions in country $i$. Estimates of equation (3) (see Table 6) show that individualism remains significant even after including institutions in the OLS and IV specifications. Individualism thus has a robust effect that is separate from institutions. The size of the estimated coefficient remains substantial. A one standard deviation increase in the individualism score leads to a 53 to 79 percent increase in the level of income without instrument for institutions and to a 86 to 99 percent increase in the level of income when the institutional variable is instrumented using the settler mortality variable as in Acemoglu et al. (2001). ${ }^{26}$

Note that the size of the effect of individualism on income remains fairly robust to including institutions and other controls. We cannot say the same for the institutional variable which is rather sensitive to including controls and individualism in the regression. Furthermore, the coefficient on institutions does not increase in the IV estimation (panel B) once individualism is included but rather tends to decrease, which was not the case in Acemoglu et al. (2001). Finally, the estimated effect of institutions is particularly unstable when we apply the correction for settler mortality as in Albouy (2012) and include individualism in the regression (columns 8 and 9 in panel B). We observe similar results (not reported) when we use innovation or TFP (rather than income per worker) as the dependent variable. In summary, there is an important contribution of culture to economic development that is independent of institutions. One can state that culture explains income differences across countries at least as much as institutions. However, data for institutions and cultural variables are available for a limited number of countries: Panel

\footnotetext{
${ }^{25}$ Acemoglu et al. (2001) use the average of the same data between 1985 and 1999. We find similar results (available upon request) when we use social infrastructure from Hall and Jones (1999) as a measure of institutional quality. The patterns are similar for TFP and patents per capita, see the regression results in Appendix Tables D3 and D4.

${ }^{26}$ We find similar results when we use long-run growth rates. See Appendix Table 2.
} 
B has 39 observations because of the imperfect overlap between coverage of settler mortality and individualism data. Future research should re-examine these results when more data become available.

Table 7 reports estimates of the effect of individualism on our outcome variables when we control for a variety of additional factors that have been investigated in the empirical literature on growth and other channels that might link individualism or genetic distance to growth. For example, individualism may be correlated with trust, which is often interpreted either as a cultural norm that reduces transaction costs or as a measure of social capital, which reflects the density of social networks and a culture of participation and citizenship. Using generalized trust constructed from the World Values Survey, a variable that has been widely used in the social sciences literature, we find some positive correlation between log income per worker and trust, but this relationship is not robust. Once we regress log income per worker on both individualism and trust, trust ceases to be significant while individualism remains robustly significant and quantitatively important. ${ }^{27}$ In Gorodnichenko and Roland (2011), we look at a large number of alternative available measures of culture (including the other Hofstede indicators) and conclude that there is no significant or robust effect on growth from cultural dimensions that are independent from the individualism-collectivism dimension. When analyzing the effect of culture on growth, the individualism-collectivism dimension thus appears to be the most relevant and robust relevant cultural variable. Note that this also further validates our use of genetic distance as a valid instrument for individualism since other cultural channels are either nonrobust or correlated with individualism.

Likewise, ethnic fractionalization, which previous literature found to be associated with weaker institutions and hence lower levels of output, does not appear be a robust predictor of output, patents or productivity. Furthermore, we do not find a statistically significant relationship between ethnic fractionalization - which also proxies for diversity - and output or any material change in the estimates of the coefficients on individualism when we augment this specification with nonlinear terms in ethnic fractionalization (not reported) and, therefore, our results for individualism are different from and not confounded by the diversity effects emphasized by Ashraf and Galor (2013).

One may argue that individualism is likely to arise only when the level of education is high, and thus that individualism may proxy for the quality of human capital instead of having an independent effect on economic outcomes. To rule out this alternative explanation, we control for the Barro-Lee measure of average years of schooling for people over the age of 15 . This variable is only significant in regressions on $\log$ TFP (columns (5) and (6)) and its inclusion does not affect the significance of individualism.

Similar to our previous specifications, we also control for average protection against expropriation risks, the share of people with a European descent in 1900, and legal origins, three popular measures of

\footnotetext{
${ }^{27}$ Although the raw correlation between trust and genetic distance is significant, this correlation disappears after controlling for basic factors such as longitude/latitude, landlocked dummy, etc. We cannot exclude that this lack of robustness for measures of trust stems from the noisiness of responses in the World Values Surveys.
} 
institutional quality. While legal origins and the share of people with a European descent do not have a robust association with our economic outcomes after controlling for other factors, protection against expropriation risks has a strong and robust association with the outcomes. Including these measures as additional regressors, however, does not alter our conclusions about the strong effects of individualism on income, patents, and productivity.

Genetic distance may reflect geographical distance and thus capture transport costs in international trade (see e.g. Giuliano et al., 2006), as well as the speed of technology diffusion rather than differences in cultural attributes. To address this concern, we introduce the log of the population-weighted distance of a country from the UK, which proxies for transportation costs from the cradle of the Industrial revolution. Although this distance variable is negatively correlated with the log of income per worker, when it is combined with the individualism score, it is not statistically significant while individualism remains robustly significant both in the OLS and IV specifications.

We argue that individualism's effect on growth works through a higher level of innovation. It is possible, however, that instead of creating new technologies and products, individualism leads to higher income and productivity only or mainly through faster absorption of existing technologies as argued by Fogli and Veldkamp (2012). In other words, diffusion of technologies may be faster in more individualistic societies, hence leading these societies to enjoy higher levels of productivity and income. We have already shown that individualism influences the intensity of creation of new technologies and goods as measured by patents. To further separate these two channels, we control for the extensive margin (the average time lag for a technology to appear in a country since the technology is invented) and the intensive margin (the speed at which a technology spreads in a country) of technology diffusion constructed by Comin and Mestieri (2013). Specifically, we average the values of a margin for each country across 25 technologies (e.g., internet, synthetic fiber, cars) ${ }^{28}$ and use these averages as additional regressors. If the diffusion channel matters more than the innovation channel, we should observe individualism becoming statistically and economically insignificant once we control for measures of the speed of technology diffusion. If the opposite is true, then including measures of the speed of technology diffusion should have no material effect on the estimated coefficients on individualism. We find that while these two margins of diffusion are strongly correlated with our outcome variables, the margins are not systematically correlated with the outcomes once we control for other country characteristics. Moreover, the coefficients on individualism are barely affected, suggesting that individualism matters more because of the innovation channel than because of the speed of diffusion channel. Again, this is clear evidence consistent with the channel we posited in this paper between individualism and long-run growth.

\footnotetext{
${ }^{28}$ Because the speed of technology diffusion varied over time, we follow Fogli and Veldkamp (2012) and project a margin of technology diffusion on technology fixed effects and use the residual from this projection to calculate the country average for a given margin. Results are similar if we do not control for technology fixed effects.
} 
The control function approach adopted in Table 7 is likely to bias the estimate of individualism's effect downward. Indeed, many of the controls (trust, education, etc.) are potentially endogenous but we do not have credible instruments for all of these variables and the data sets for which all instruments could overlap would be considerably smaller, as was already the case in Table 6 when combining only instruments for culture and institutions. These potentially endogenous regressors are likely to be correlated with our instrumental variables and the error terms across first- and second-stage regressions are plausibly positively correlated. Therefore, by not instrumenting these potentially endogenous variables, our IV regressions in Table 7 are likely to attribute some of the effects of individualism to these other regressors (see Appendix B for a more formal derivation of this result). Thus, one could interpret our estimates on the individualism coefficients as conservative and, if we find a significant positive effect of individualism on growth, the true effect is likely to be larger.

In summary, although genetic distance may be correlated with non-cultural factors or cultural factors other than individualism, none of the popular alternatives alters our main result that individualism plays an important role in determining economic development.

\section{Causal channels between culture and institutions.}

Given that individualism plays a role that is independent of institutions, we naturally want to examine whether individualism affects institutions or vice versa. Arguments could go both ways. One can reason that culture shapes institutions. When institutions are put in place, they correspond to a view of how the world works and are thus based on culture. The political transformations that took place in the Western world between the eighteenth and twentieth century from absolute monarchy and autocracy to republican and democratic regimes can be seen as based on the values of the Enlightenment that go back to the Renaissance period and the rediscovery and reappropriation of the Greek culture of rationality and democracy. The French revolution led to the abolition of monarchy and profound institutional changes that were inspired by the ideals of the Enlightenment. In contrast, large-scale revolts in China throughout its history led at best to the replacement of one emperor/dynasty by another one (Finer, 1997) because the Chinese imperial system was in line with the Confucianist culture and its view of the "good emperor" as father figure with the associated moral duties towards the people. Within that culture, dissatisfaction of the population tended to be interpreted as resulting from having a "bad" emperor. Replacing the latter with a "good" emperor who would behave according to the Confucianist moral cannons was thus seen as the appropriate response. Culture can thus be argued to affect institutional choices of a society.

However, one can also make a case in favor of an opposite causal channel. People lived for centuries under empires characterized by different institutional organizations, be it the Chinese imperial system, the Ottoman Empire or the Austro-Hungarian Empire. The administrative apparatus of empires (as well as of 
smaller political entities) made it possible to influence the world view of people living within its boundaries, usually by the spreading of religions such as Islam under the Ottoman Empire or Catholicism under the Austro-Hungarian Empire. ${ }^{29}$ For example, Confucianism became widespread in China in part because it was adopted as the official ideology of the empire as early as the Han dynasty. Institutions can thus be argued to have affected the spread of a specific culture, and thus also the degree of individualism and collectivism.

We thus test for the existence of two causal channels: from culture to institutions and from institutions to culture. For this test we employ two econometric specifications:

$$
\begin{aligned}
& I N S T_{i}=v_{0} I N D_{i}+\beta_{0} X_{i}+e_{i} \\
& I N D_{i}=v_{1} I N S T_{i}+\beta_{1} X_{i}+u_{i}
\end{aligned}
$$

where INST is a measure of institutions (i.e., protection against expropriation risk as in Acemoglu et al. (2001)), IND is a measure of individualism, $X$ is a vector of controls, and $e$ and $u$ are error terms. In equation (4), individualism is instrumented with the blood distance we constructed before. In equation (5), protection against expropriation risk is instrumented with settler mortality. If we find that $v_{0}$ is significant while $v_{1}$ is not, culture can be interpreted as causing institutions. If $v_{1}$ is significant while $v_{0}$ is not, institutions can be interpreted as causing culture. Joint significance of $v_{0}$ and $v_{1}$ can be understood as causation flowing both ways. The validity of these results will of course depend on the validity of the instruments used.

The results for equation (4) are reported in Panel A of Table 8. The effect of individualism on the strength of economic institutions is positive and significant thus implying a flow of causality from individualistic culture to institutions. ${ }^{30}$ This finding corroborates Tabellini (2008a) and Licht et al. (2007) who found similar results using different measures for culture and institutions. We report results for equation (5) in Panel B of Table 8. They indicate that causality also flows from institutions to culture when we use as instrument settler mortality from Acemoglu et al. (2001). However, the effect of institutions on culture ceases to be significant once one introduces settler mortality from Albouy (2012) and the first stage fit becomes quite poor. Hence, the effect of institutions on culture might be less robust than the other way round. One must however be careful in interpreting all these results since they are based only on 39 observations, the countries for which the data on culture and institutions and their instruments overlap. In short, culture appears to have a causal effect on institutions and is itself influenced by institutions, although the latter direction of causation is less clear cut than the former.

\section{Within-country evidence}

\footnotetext{
${ }^{29}$ Grosjean (2009) finds that having lived together under the same empire for more than 100 years reduced a measure of cultural distance between two localities by at least a third.

${ }^{30}$ The sample size is restricted to be the same across panels in Table 8 . The estimates of $v_{0}$ tend to be larger and more precisely estimated (thus yielding high statistical significance) when we allow for the maximum country coverage.
} 
Cross-country analysis may fail to control fully for differences in institutional factors or other sources of cross-country differences. However, we can examine the effect of culture within a given country, thereby holding institutional factors constant. Furthermore, by exploring within country variation, we can rule out alternative explanations based on differences in diffusion costs, geography, etc. Specifically, our model predicts that more individualistic cultures should ceteris paribus stimulate persons to choose research-oriented occupations that require independent thought and deviation from traditional ways of doing things. For this analysis, the USA is a particularly attractive research object since this country has many ethnicities and occupational opportunities that are relatively open for peoples of all origins and cultures. This special feature of the USA has been exploited by the epidemiological approach to culture pioneered by Fernandez and coauthors (see Fernandez, 2010), Giuliano (2007), Algan and Cahuc (2010), and others.

We use ethnicity, age, gender, birth place, educational attainment from the 1 percent and 5 percent public micro data (IPUMS) of the U.S. Census in 1970 and 2000 respectively. For the 2000 census, ethnicity is based on the respondent's self-reported country of ancestry. For the 1970 census, ethnicity is based on the respondent's response about the father's birth place. Our sample includes only employed males who are aged between 25 and 60 and have non-missing information on ancestors (country of origin). The reason why we constrain the sample only to individuals with non-missing ethnicity information is because we then focus only on individuals who associate themselves with a particular culture (which could be different from the American one) and are likely to observe the traditions of their original cultures. We exclude females, unemployed and other ages to minimize the various possible selection effects.

We consider several sub-samples. The first sample split is determined by whether an individual is born in the USA so that we can attenuate the effects of high-human-capital migration into the USA (intuitively, high-human-capital migration from countries with low level of individualism could create a sample of highly individualistic U.S. persons from these countries, and thus the difference between persons from individualistic cultures/countries and collectivist cultures/countries would not be reflected in the sample). The second sample split is based on educational attainment: all persons vs. persons with a bachelor (or higher) degree. The higher is the level of educational attainment, the smaller should be the effect of differences in initial conditions and abilities across ethnicities on the estimates.

Our approach has two steps. In the first step, we estimate the following probit:

$$
R O O_{i}=\Phi\left(X_{i} \beta+\Sigma_{k} \alpha_{k} D_{i k}+\text { error }\right)
$$

where $i$ and $k$ index individuals and ethnic groups, ROO is a dummy variable equal to one if an individual has a research oriented occupation and zero otherwise, $D$ is a set of dummies of each ethnicity, and the vector $X$ includes controls such as age, age squared, and a set of dummies for educational attainment. The omitted category in the set of ethnic dummy variables is British since the U.K. is the second most individualistic country in our sample. 
In the second step we estimate the following specification by least squares: ${ }^{31}$

$\hat{\alpha}_{k}=\theta \times I N D_{k}+$ error

where $\hat{\alpha}_{k}$ is the set of estimated coefficients $\hat{\alpha}$ in regression (6) and IND is Hofstede's individualism score. Our theory predicts that $\theta$ should be positive.

Table 9 presents estimates from regression (7). Note that the estimate of $\theta$ is larger when we constrain the sample only to U.S. born persons and when we consider persons with a certain educational threshold. The estimates of $\theta$ indicate that persons coming from individualistic cultures are more likely to take research-oriented occupations than persons from collectivist cultures. Obviously, these estimates do not prove that persons from individualist cultures are more successful at innovation than persons from collectivist cultures but they clearly suggest that there is a cultural component at work in the choice of such occupations.

\section{Concluding remarks}

We consider the hypothesis that individualism/collectivism can influence economic outcomes such as innovation and long-run growth and test this hypothesis using cross-country and micro-level data. Our evidence documents a strong relationship between these cultural attributes and economic outcomes even after controlling for a broad range of alternative explanations. Although one should be cautious in interpreting our results as causal—we rely on non-experimental data and therefore cannot rule out omitted factors completely-our instrumental variable estimates as well as a large battery of checks and tests provide preponderance of evidence suggesting a plausible causal interpretation of this relationship.

There are clearly many pitfalls that should be avoided in interpreting our results. By no means should our (or other) research on economic effects of culture be seen as implying a "ranking" of cultures in the world or a call for cultural revolutions. On the contrary, this research is aimed to better understand the tradeoffs implied by different cultures which are deeply rooted in history and change very slowly. We must better understand the world we live in and the values and beliefs upon which people in different countries base their expectations, judgments and calculations. Identifying effects of culture on economic outcomes should be interpreted in a way that leads to better dialogue and communication across cultures.

On a more practical side, this research can help pinpoint effective margins of development policy and aid programs to developing countries. Depending on the strengths of various cultures, different emphases may have to be put on a spectrum of available policy tools. For example, aid for programs providing public goods may be more effective in collectivist societies than in individualist societies. In the latter, aid programs counting on local initiatives might be more effective. Alternatively, organizational support may have to be stronger for infrastructure projects in individualist societies, whereas in collectivist societies one may have to make special effort to encourage creative initiatives.

${ }^{31}$ To minimize the effect of outliers, we use Huber robust least squares regression. 
Research on the economic effects of culture is still in its infancy. We hope that our results showing the importance of culture for long-run growth will help to spur research in this direction.

\section{References}

Acemoglu, D., S. Johnson, and J. Robinson (2001) "The Colonial Origins of Comparative Development: An Empirical Investigation," American Economic Review 91, 1369-1401.

Acemoglu, D., S. Johnson, and J. Robinson (2002) "Reversal of Fortune: Geography and. Institutions in the Making of the Modern World Income Distribution," Quarterly Journal of Economics 117(4), 1231-94.

Aghion, Ph., and P. Howitt (1998) Endogenous Growth Theory MIT Press, Cambridge Mass.

Aghion, Ph., and P. Howitt (2009) The Economics of Growth MIT Press, Cambridge Mass.

Aghion, Ph., Y. Algan, P. Cahuc, and A. Shleifer (2010) "Regulation and Distrust," Quarterly Journal of Economics 125(3), 1015-1049.

Aiello, F., and V.Scoppa (2000) "Uneven Regional Development in Italy: Explaining Differences in Productivity Levels," Giornale degli Economisti 59(2), 270-298.

Albouy, David. 2012. "The Colonial Origins of Comparative Development: An Empirical Investigation: Comment," American Economic Review 102(6), 3059-3076.

Algan, Y., and P. Cahuc (2010) "Inherited Trust and Growth," American Economic Review 100(5), 20602092.

Ashraf, Q., and O. Galor (2007) "Cultural Assimilation, Cultural Diffusion and the Origin of the Wealth of Nations" CEPR Working Paper No 6444, London UK.

Ashraf, Q., and O. Galor (2013) "The Out of Africa Hypothesis, Human Genetic Diversity and Comparative Development," American Economic Review 103(1), 1-46.

Barro, R.J., and J.W. Lee (2001) "International Data on Educational Attainment: Updates and Implications," Oxford Economic Papers 53(3), 541-563.

Barro, R.J., and R.M. McCleary (2003) "Religion and Economic Growth Across Countries," American Sociological Review 68(5), 760-781.

Bisin, A., and T. Verdier (2000) "“'Beyond The Melting Pot”: Cultural Transmission, Marriage, And The Evolution Of Ethnic And Religious Traits," Quarterly Journal of Economics 115, 955-988.

Bisin, A., and T. Verdier (2001) "The Economics of Cultural Transmission and the Dynamics of Preferences,"Journal of Economic Theory 97, 298-319.

Bond, M., and P. Smith (1996) "Culture and Conformity: A Meta-analysis of studies using Asch's (1952b, 1956) line Judgment Task," Psychological Bulletin 119(1), 111-137.

Cavalli-Sforza, L. L., P. Menozzi, and A. Piazza (1994). The History and Geography of Human Genes. Princeton University Press.

Chiao, J.Y., and K.D. Blizinsky (2010) "Culture-gene coevolution of individualism-collectivism and the serotonin transporter gene," Proceedings - Royal Society. Biological sciences 277(1681), 529-537.

Clark, G. (2007) A Farewell to Alms. A Brief Economic History of the World. Princeton Univ. Press.

Comin, D. and M. Mestieri (2013) "If Technology has arrived everywhere, why has income diverged?" mimeo Harvard University.

Corneo, G., and O. Jeanne (2010) "Symbolic values, occupational choice, and economic development," European Economic Review 54(2), 237-251.

De Mooij, M. (2003) "Convergence and Divergence in Consumer Behaviour: Implications for Global Advertising," International Journal of Advertising 22(2), 183-202

Doepke, M., and F. Zilibotti (2008) "Occupational Choice and the Spirit of Capitalism," Quarterly Journal of Economics 123(2), 747-793.

Doepke, M., and F. Zilibotti (2013) “Culture, Entrepreneurship and Growth” in P. Aghion and S. Durlauf (ed.) Handbook of Economic Growth vol. 2 Elsevier Amsterdam, 1-48.

Easterly, W., M. Kremer, L. Prichett, and L. Summers (1993) "Good policy or good luck? Country growth performance and temporary shocks," Journal of Monetary Economics 32(3), 459-483.

Economist Intelligence Unit (2007) Innovation: Transforming the way business creates. www.eiu.com. 
Economist Intelligence Unit (2009) A new ranking of the world's most innovative countries. www.eiu.com.

Evenson, R., and L. Westphal (1995) "Technological Change and Technology Strategy" in Handbook of Development Economics, vol. 3, 2209-2299, Elsevier Amsterdam.

Fearon, J. (2003) "Ethnic and Cultural Diversity by Country," Journal of Economic Growth 8(2), 195-222.

Fernandez, R. (2010) "Does Culture Matter?" in J. Benhabib, A. Bisin and M. Jackson (ed.) Handbook of Social Economics, Vol. 1A, North-Holland, 481-510.

Fernandez (2013) "Cultural Change as Learning: The evolution of female labor force participation over a century," American Economic Review 103(1), 472-500.

Fernandez, R., A. Fogli and C. Olivetti (2004) "Mothers and Sons: Preference Formation and Female Labor Force Dynamics," Quarterly Journal of Economics 119(4), 1249-1299.

Fernandez, R., and A. Fogli (2009) "Culture: An Empirical Investigation of Beliefs, Work and Fertility," American Economic Journal: Macroeconomics 1(1), 146-177.

Fincher, C.L., R. Thornhill, D.R. Murray, and M. Schaller (2008) "Pathogen prevalence predicts human cross-cultural variability in individualism/collectivism" Proceedings - Royal Society. Biological sciences 275(1640), 1279-1285.

Finer, S. (1997). The History of Government, volumes I-III, Oxford University Press, Oxford.

Fogli, A., and L. Veldkamp (2012) "Germs, Social Networks and Growth,” mimeo.

Giuliano, P. (2007) "Living Arrangements in Western Europe: Does Cultural Origin Matter?" Journal of the European Economic Association 5, 927-952.

Giuliano, P., A. Spilimbergo, and G. Tonon (2014) "Genetic distance, transportation costs, and trade," Journal of Economic Geography 14(1), 179-198.

Goncalo, J.A., and B.M. Staw (2006) "Individualism-collectivism and group creativity," Organizational Behavior and Human Decision Processes 100, 96-109.

Gorodnichenko, Y. and G. Roland (2011) "Which Dimensions of Culture Matter for Long-Run Growth?" American Economic Review. Papers and Proceedings 101(3), 492-498.

Greif, A. (1994) "Cultural Beliefs and the Organization of Society: A Historical and Theoretical Reflection on Collectivist and Individualist Societies," Journal of Political Economy 102, 912-950.

Greif, A. (2006). Institutions and the Path to the Modern Economy: Lessons from Medieval Trade. Cambridge University Press.

Grosjean, P. (2009) "The Contributions of Spatial Proximity and History to Cultural Integration: A Gravity Approach", mimeo, UC Berkeley.

Grossman, G., and E. Helpman (1991) Innovation and Growth in the Global Economy. MIT Press Cambridge Mass.

Guiso, L., P. Sapienza, and L. Zingales (2003) "People's Opium? Religion and Economic Attitudes." Journal of Monetary Economics 50: 225-282.

Guiso, L., P. Sapienza, and L. Zingales (2009) "Cultural Biases in Economic Exchange," Quarterly Journal of Economics 124(3), 1095-1131.

Hall, R. E., and C.I. Jones (1999) "Why Do Some Countries Produce So Much More Output Per Worker Than Others?" Quarterly Journal of Economics 114(1), 83-116.

Harrison, I. (2004) Book of Inventions, Cassel Illustrated, London.

Heine, S.J. (2007) Cultural psychology. W. W. Norton \& Company.

Hofstede, G. (2001) Culture's Consequences: Comparing Values, Behaviors, and Organizations Across Nations. $2^{\text {nd }}$ edition. Sage Publications.

Hoppe, M.H. (1990) A comparative study of country elites: international differences in work-related values and learning and their implications for management training and development" Ph.D. thesis University of North Carolina at Chapel Hill.

Huang, Y., J. Lin, and Y. Qian (2013) "Does ethnicity pay? Evidence from overseas Chinese FDI in China," Review of Economics and Statistics 95(3), 868-883.

Inglehart, R.F., S. Borinskaya, A. Cotter, J. Harro, R.C. Inglehart, E. Ponarin, and C. Welzel, 2014. "Genetic Factors, Cultural Predispositions, Happiness and Gender Equality," Journal of Research in Gender Studies 4(1), 32-100. 
Jellema, J. (2009) "Cultural Variation, Genetic Heterozygosity and Economic Development," mimeo.

Jellema, J., and G. Roland (2011) "Institutional Clusters and Economic Performance," Journal of Economic Behavior and Organizations 79(1-2), 108-132.

Jones, C. I. (2002) Introduction to Economic Growth. W.W. Norton New York.

Jones, C. I., and P. Romer (2010) "The New Kaldor Facts: Ideas, Institutions, Population, and Human Capital," American Economic Journal: Macroeconomics 2(1), 224-245.

Kashima, E., and Y. Kashima (1998). "Culture and language: The case of cultural dimensions and personal pronoun use," Journal of Cross-Cultural Psychology 29, 461-486.

Klenow, P. and A. Rodriguez-Clare (1997) "Economic growth: A review essay," Journal of Monetary Economics 40(3), 597-617.

Knack, S., and P. Keefer (1997) "Does Social Capital Have an Economic Payoff? A Cross-Country Investigation," Quarterly Journal of Economics 112(4), 1251-1288.

La Porta, R., F. Lopez-de-Silanes, A. Shleifer, and R. Vishny. 1998. "Law and Finance." Journal of Political Economy 106(6), 1113-1155.

La Porta, R., F. Lopez-de-Silanes, and A. Shleifer (2008) "The Economic Consequences of Legal Origins," Journal of Economic Literature 46(2), 285-332.

Landes, D. S. (1998) The Wealth and Poverty of Nations. Norton Publishers, New York.

Licht, A. N., C. Goldschmidt, and Shalom H. Schwartz (2007) "Culture Rules: The Foundations of the Rule of Law and Other Norms of Governance," Journal of Comparative Economics 35(4), 659-688.

Liker, J. (2003) The Toyota Way. McGraw-Hill.

Macfarlane, A. (1978) The Origins of English Individualism: Family, Property and Social Transition. Blackwell, Oxford.

Maddison, A. (2003) The World Economy. Historical Statistics OECD, Paris.

Merrit, A. (2000) "Culture in the cockpit: Do Hofstede's Dimensions replicate?" Journal of Cross-Cultural Psychology 31(3), 283-301.

Merton, R. K. (1973) The Sociology of Science: Theoretical and Empirical Investigations. University of Chicago Press.

Mourant, A.E., Ada C. Kopec, and Kazimiera Domaniewska-Sobczak (1976) The Distribution of the Human Blood Groups and Other Polymorphisms. Oxford University Press.

Murdock, G. (1967) Ethnographic Atlas. Pittsburgh, PA: University of Pittsburgh Press.

Murrell, P., and M. Schmidt (2011) "The Coevolution of Culture and Institutions in Seventeenth Century England", mimeo, University of Maryland.

Murray, Damian R., and Mark Schaller (2010) "Historical Prevalence of Infectious Diseases Within 230 Geopolitical Regions: A Tool for Investigating Origins of Culture," Journal of Cross-Cultural Psychology 41(1), 99-108.

North, D. (1990) Institutions, Institutional Change and Economic Performance. Cambridge University Press.

Platteau, Jean-Philippe (2000) Institutions, Social Norms and Economic Development, Harwood Academic Publishers Newark New Jersey.

Pritchard, J.K., and M. Przeworski (2001) "Linkage disequilibrium in Humans: Models and Data". American Journal of Human Genetics 69 (1), 1-14.

Putnam, R.D. (1994) Making democracy work: Civic traditions in modern Italy. Princeton Univ. Press.

Putterman, L., and D.N. Weil (2010) "Post-1500 Population Flows and the Long-Run Determinants of Economic Growth and Inequality," Quarterly Journal of Economics 125(4), 1627-1682.

Redding, S., and A.J. Venables (2004) "Economic geography and international inequality," Journal of International Economics 62(1), 53-82.

Roland, G. (2004) "Understanding Institutional Change: Fast-moving and Slow-moving Institutions." Studies in Comparative International Development 38: 109-131.

Schwartz, S. H. (1994) "Beyond Individualism/Collectivism: New Cultural Dimensions of Values" in Uichol K. et al, eds., Individualism and Collectivism: Theory, Method, and Applications. Sage.

Schwartz, S. H. (2006) "A Theory of Cultural Value Orientations: Explication and Applications," Comparative Sociology 5(2-3), 137-182. 
Shane, S. (1995) "Uncertainty avoidance and the Preference for Innovation Championing Roles", Journal of International Business Studies 26(1): 47-68.

Spolaore, E., and R. Wacziarg (2009) “The Diffusion of Development," Quarterly Journal of Economics 124(2), 469-529.

Spolaore, E., and R. Wacziarg (2013) "How Deep Are the Roots of Economic Development?" Journal of Economic Literature 51(2), 325-369.

Tabellini, G. (2008a) "The Scope of Cooperation: Values and Incentives," Quarterly Journal of Eocnomics 123(3), 905-950.

Tabellini, G. (2008b) "Institutions and Culture. Presidential Address European Economic Association," Journal of the European Economic Association 6, 255-294.

Tabellini, G. (2010) "Culture and Institutions: Economic Development in the Regions of Europe," Journal of the European Economic Association 8(4), 677-716.

Tills, D., A. C. Kopec, and R. E. Tills (1983) The Distribution of the Human Blood Groups and Other Polymorphisms. Oxford University Press.

Van Nimwegen, T. (2002) "Global Banking, Global values: The in-house reception of the corporate values of ABN-AMRO" Ph.D. dissertation Nyenrode University Delft, Netherlands.

Way, B.M. and M.D. Lieberman (2010) "Is there a genetic contribution to cultural differences? Collectivism, individualism and genetic markers of social sensitivity," Social Cognitive \& Affective Neuroscience 5(2-3), 203-211.

Weber, M. (2002) The Protestant Ethic and the Spirit of Capitalism, translated by Stephen Kalberg, Oxford University Press, Oxford U.K. 
Table 1. Income and individualism.

\begin{tabular}{|c|c|c|c|c|c|c|c|c|}
\hline & \multirow{3}{*}{ OLS } & \multicolumn{7}{|c|}{ Instrumental variables } \\
\hline & & \multirow{2}{*}{$\begin{array}{c}\text { Blood } \\
\text { distance } \\
\text { from the UK }\end{array}$} & \multicolumn{2}{|c|}{$\begin{array}{l}\text { Frequency of short (S) allele } \\
\text { in the polymorphic region } \\
\text { 5HTTLPR of serotonin } \\
\text { transporter gene (SLC6A4) }\end{array}$} & \multicolumn{2}{|c|}{$\begin{array}{l}\text { Frequency of } \mathrm{G} \text { allele in } \\
\text { polymorphism A } 118 \mathrm{G} \\
\text { in } \mu \text {-opoid receptor gene }\end{array}$} & \multicolumn{2}{|c|}{$\begin{array}{l}\text { Historical pathogen } \\
\text { prevalence index }\end{array}$} \\
\hline & & & Separate & $\begin{array}{l}\text { Combined } \\
\text { with blood } \\
\text { distance }\end{array}$ & Separate & $\begin{array}{l}\text { Combined } \\
\text { with blood } \\
\text { distance }\end{array}$ & Separate & $\begin{array}{c}\text { Combined } \\
\text { with blood } \\
\text { distance }\end{array}$ \\
\hline & $(1)$ & $(2)$ & (3) & (4) & $(5)$ & $(6)$ & $(7)$ & $(8)$ \\
\hline Individualism & $\begin{array}{l}0.030^{* * *} \\
(0.003)\end{array}$ & $\begin{array}{r}\mathrm{Se} \\
0.046^{* * * *} \\
(0.007)\end{array}$ & $\begin{array}{c}\text { stage: regre } \\
0.020^{* *} \\
(0.010)\end{array}$ & $\begin{array}{c}\text { of log incom } \\
0.034 * * * \\
(0.008)\end{array}$ & $\begin{array}{l}\text { Norker on in } \\
0.020^{* * *} \\
(0.006)\end{array}$ & $\begin{array}{l}\text { idualism } \\
0.026^{* * * *} \\
(0.006)\end{array}$ & $\begin{array}{l}0.043 * * * \\
(0.006)\end{array}$ & $\begin{array}{l}0.039 * * * \\
(0.005)\end{array}$ \\
\hline $\begin{array}{l}\text { Alternative IV } \\
\text { Blood distance }\end{array}$ & & $\begin{array}{l}-15.929 * * * \\
(2.373)\end{array}$ & $\begin{array}{l}\text { age: regressic } \\
-1.027 * * * \\
(0.223)\end{array}$ & $\begin{array}{l}\text { f individualisn } \\
-0.445 \\
(0.300) \\
-13.051^{*} \\
(4.560)\end{array}$ & $\begin{array}{l}-1.494 * * * \\
(0.312)\end{array}$ & $\begin{array}{l}-0.690 \\
(0.480) \\
-13.452 * * * \\
(5.213)\end{array}$ & $\begin{array}{l}-23.038 * * * \\
(2.238)\end{array}$ & $\begin{array}{l}-17.535 * * * \\
(2.239) \\
-8.461 * * * \\
(2.481)\end{array}$ \\
\hline Observations & 96 & 96 & 43 & 43 & 34 & 34 & 96 & 96 \\
\hline $\begin{array}{l}\mathrm{R}^{2} \\
1^{\text {st }} \text { stage F-stat } \\
\text { Over-id test p-value }\end{array}$ & 0.377 & $\begin{array}{l}0.277 \\
45.04\end{array}$ & $\begin{array}{l}0.471 \\
22.46\end{array}$ & $\begin{array}{l}0.336 \\
21.77 \\
0.110 \\
\end{array}$ & $\begin{array}{l}0.507 \\
22.97\end{array}$ & $\begin{array}{l}0.540 \\
25.56 \\
0.250 \\
\end{array}$ & $\begin{array}{l}0.178 \\
116.1\end{array}$ & $\begin{array}{l}0.215 \\
66.53 \\
0.410 \\
\end{array}$ \\
\hline
\end{tabular}

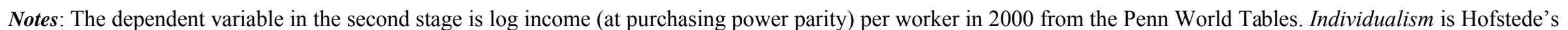

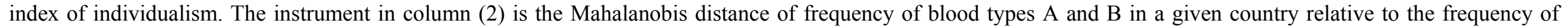

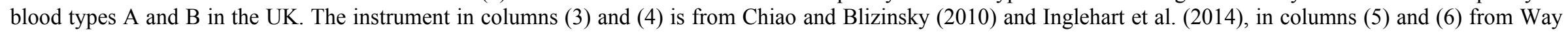

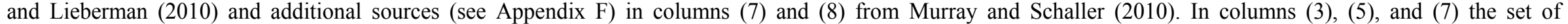

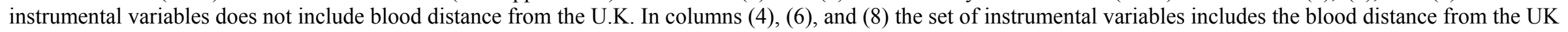

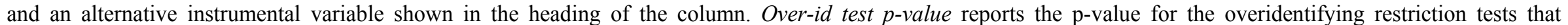

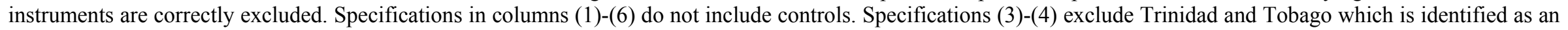

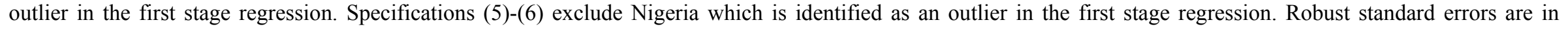
parentheses. $* * *, * *, *$ denote significance at $0.01,0.05$, and 0.10 levels. 
Table 2. Robustness checks: Income and individualism.

\begin{tabular}{|c|c|c|c|c|c|c|}
\hline Row & Modification & $\begin{array}{l}\text { Coef. } \\
\text { (s.e.) }\end{array}$ & Obs. & $\begin{array}{l}\text { First stage } \\
\text { F-stat }\end{array}$ & $\begin{array}{l}\text { First stage } \\
\text { partial R } \\
\end{array}$ & $\begin{array}{l}\text { Over-id } \\
\text { p-value }\end{array}$ \\
\hline$(1)$ & Blood distance to USA & $\begin{array}{l}0.040 * * * \\
(0.007)\end{array}$ & 96 & 31.30 & 0.275 & \\
\hline (2) & Frequency of blood types A \& B separately & $\begin{array}{l}0.051^{* * * *} \\
(0.008)\end{array}$ & 96 & 26.34 & 0.313 & 0.250 \\
\hline (3) & Red Cross blood info & $\begin{array}{l}0.040^{* * * *} \\
(0.012)\end{array}$ & 37 & 18.34 & 0.363 & \\
\hline (4) & $\begin{array}{r}\text { Spolaore-Wacziarg } \\
\text { First distance }\end{array}$ & $\begin{array}{l}0.071 * * * \\
(0.013)\end{array}$ & 96 & 22.31 & 0.184 & \\
\hline (5) & Nei distance & $\begin{array}{l}0.068^{* * * *} \\
(0.012)\end{array}$ & 96 & 22.33 & 0.191 & \\
\hline (6) & $\begin{array}{l}\text { Pronoun drop } \\
\text { As a separate instrument }\end{array}$ & $\begin{array}{l}0.022 * * * \\
(0.005)\end{array}$ & 38 & 41.26 & 0.535 & \\
\hline (7) & Combined with blood distance & $\begin{array}{l}0.027 * * * \\
(0.005)\end{array}$ & 39 & 36.96 & 0.646 & 0.270 \\
\hline (8) & $\begin{array}{c}\text { Dyadic regressions } \\
\text { Baseline }\end{array}$ & $\begin{array}{l}0.056^{* * *} \\
(0.013)\end{array}$ & 4,656 & 17.63 & 0.027 & \\
\hline (9) & + control for country fixed effect & $\begin{array}{l}0.075^{* * *} \\
(0.010)\end{array}$ & 4,656 & 40.31 & 0.061 & \\
\hline (10) & + control for geographic distance & $\begin{array}{l}0.109^{* * *} \\
(0.021)\end{array}$ & 4,656 & 14.50 & 0.026 & \\
\hline
\end{tabular}

Notes: the dependent variable log income per worker (at purchasing power parity) in 2000 is from the Penn World Tables. Individualism is Hofstede's index of individualism. A larger value of the index corresponds to a greater level of individualism. In row (1), Blood Distance is computed relative to the USA (instead of the UK). In row (2), we use raw frequencies (i.e., no distance) of blood types A and B as separate instruments. Over-id p-value is the p-value for the overidentifying restrictions test. In row (3), Blood Distance (relative to the UK) is computed based on data available from the Red Cross and similar agencies. In rows (4) and (5), the distance between nations is taken from Spolaore and Wacziarg (2009) who use a broader set of genetic polymorphisms. The first and Nei genetic distances for a given gene are computed as follows. Let $p_{i j}$ be the frequency of gene $i$ with $L$ alleles in populations $j=1,2$. Then the first distance is $F_{S T, j}=\sum_{i=1}^{2}\left(p_{i j}-\bar{p}_{i}\right)^{2} /\left(\bar{p}_{i}\left(1-\bar{p}_{i}\right)\right)$ where $\bar{p}_{i}=\frac{1}{2}\left(p_{i 1}+p_{i 2}\right)$ and the Nei distance is $F_{N}=$ $-\log \left\{J_{12} /\left(J_{11} J_{22}\right)^{0.5}\right\}$ where $J_{12}=\sum_{k=1}^{L} \sum_{m=1}^{L} p_{k 1} p_{m 2}$ and $J_{d d}=1-\sum_{m=1}^{L} p_{m d}^{2}, d=\{1,2\}$. See Table 1.10 .1 in Cavalli-Sforza et al. (1994) for a more detailed description of how the first and Nei genetic distances are constructed. In rows (6) and (7), the linguistic instrument Pronoun drop dummy is a dummy variable (from Licht et al. 2007) equal to one if a language permits dropping a pronoun in sentences and zero others. In row (6), only Pronoun drop dummy is used as an instrumental variable. In row (7), Pronoun drop dummy and Blood Distance are instrumental variables. Robust standard errors are in parentheses. Specifications in rows (1)-(7) do not include controls. Rows (8)-(10) report IV estimates for the dyadic specification (2). In row (8), the only regressor is the difference between individualism scores in a pair of countries. In row (9), the specification from row (8) is augmented with countries dummies. In row (10), the specification includes specification in row (9) and log geographical distance between a pair of countries. Robust standard errors are in parentheses. In rows (8)-(10), standard errors are clustered by country. ${ }^{* * *}, * *,{ }^{*}$ denote significance at $0.01,0.05$, and 0.10 levels. 
Table 3. Individualism and economic outcomes.

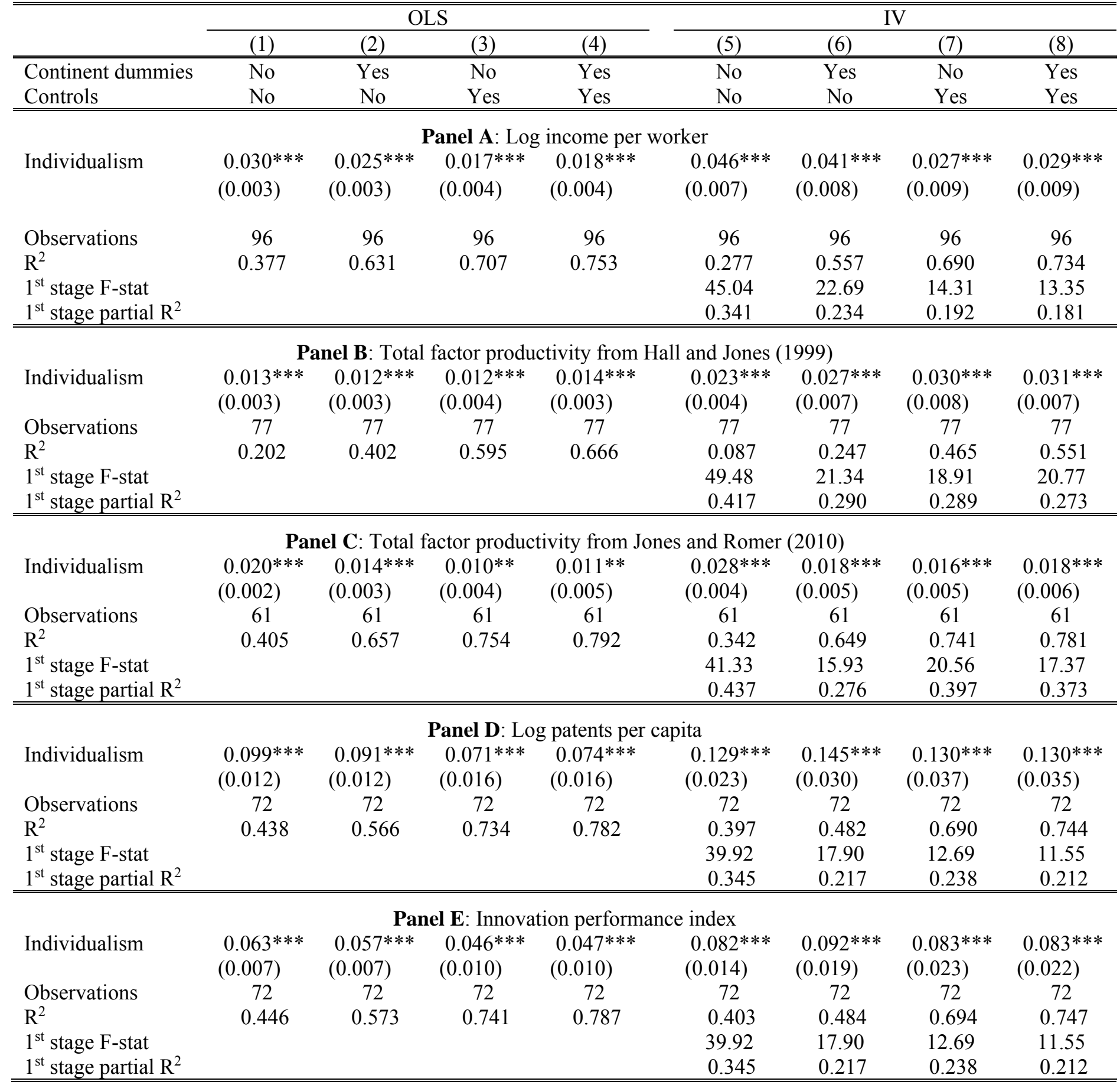

Notes: In Panel A, the dependent variable is log income (at purchasing power parity) per worker in 2000 from the Penn World Tables. In Panels B and C, the dependent variable is log total factor productivity relative to the USA from Hall and Jones (1999) and from Jones and Romer (2010). In Panels D and E, the dependent variables are log patents per million population and innovation performance index taken from Economist Intelligence Unit $(2007,2009)$. Individualism is Hofstede's index of individualism. A larger value of the index corresponds to a greater level of individualism. The instrument is the Mahalanobis distance of frequency of blood types A and B in a given country relative to the frequency of blood types A and B in the UK. Controls include a dummy for landlocked countries, the percentages of population practicing major religions in a country and absolute values of country longitude and latitude. Robust standard errors in parentheses. ${ }^{* * *}, * *, *$ denote significance at $0.01,0.05$, and 0.10 levels. 
Table 4. Income and individualism by region.

\begin{tabular}{|c|c|c|c|c|c|c|c|c|}
\hline & Asia & Europe & Africa & America & $\begin{array}{c}\text { Africa } \\
\text { Asia } \\
\text { Europe }\end{array}$ & $\begin{array}{c}\text { Africa } \\
\text { Asia }\end{array}$ & OECD & $\begin{array}{c}\text { non- } \\
\text { OECD }\end{array}$ \\
\hline & (1) & $(2)$ & (3) & (4) & $(5)$ & (6) & (7) & $(8)$ \\
\hline \multicolumn{9}{|c|}{ Panel A: OLS } \\
\hline Individualism & $\begin{array}{c}0.040 * * \\
(0.015)\end{array}$ & $\begin{array}{c}0.025 * * * \\
(0.005)\end{array}$ & $\begin{array}{c}0.039 * * \\
(0.015)\end{array}$ & $\begin{array}{c}0.018 * * * \\
(0.003)\end{array}$ & $\begin{array}{c}0.030 * * * \\
(0.005)\end{array}$ & $\begin{array}{c}0.040 * * * \\
(0.010)\end{array}$ & $\begin{array}{c}0.016^{* * *} \\
(0.005)\end{array}$ & $\begin{array}{c}0.027 * * * \\
(0.007)\end{array}$ \\
\hline Observations & 22 & 34 & 18 & 19 & 74 & 40 & 30 & 66 \\
\hline R-squared & 0.227 & 0.444 & 0.306 & 0.465 & 0.639 & 0.490 & 0.295 & 0.478 \\
\hline \multicolumn{9}{|c|}{ Panel B: IV } \\
\hline Individualism & $\begin{array}{c}0.050 * * \\
(0.025)\end{array}$ & $\begin{array}{c}0.061 * * \\
(0.025)\end{array}$ & $\begin{array}{c}0.098 * * \\
(0.046)\end{array}$ & $\begin{array}{c}0.024 * * * \\
(0.007)\end{array}$ & $\begin{array}{c}0.063 * * * \\
(0.017)\end{array}$ & $\begin{array}{c}0.065 * * * \\
(0.024)\end{array}$ & $\begin{array}{c}0.040 * * * \\
(0.014)\end{array}$ & $\begin{array}{c}0.058 * * * \\
(0.022)\end{array}$ \\
\hline Observations & 22 & 34 & 18 & 19 & 74 & 40 & 30 & 66 \\
\hline R-squared & 0.214 & -0.471 & -0.358 & 0.413 & 0.439 & 0.420 & -0.354 & 0.300 \\
\hline 1st stage F-stat & 4.879 & 4.649 & 4.815 & 8.448 & 11.46 & 8.171 & 8.409 & 8.004 \\
\hline Partial R2 & 0.262 & 0.131 & 0.179 & 0.335 & 0.150 & 0.204 & 0.267 & 0.118 \\
\hline
\end{tabular}

Notes: the dependent variable is log income (at purchasing power parity) per worker in 2000 from the Penn World Tables. Individualism is Hofstede's index of individualism. A larger value of the index corresponds to a greater level of individualism. The instrument is the Mahalanobis distance of frequency of blood types A and B in a given country relative to the frequency of blood types A and B in the UK. The specification in columns (1)-(4) does not include controls. The specification in columns (5)-(8) includes continent dummies. Robust standard errors in parentheses. ***, $* *, *$ denote significance at $0.01,0.05$, and 0.10 levels.

Table 5. Income and individualism by intensity of migration flows.

\begin{tabular}{|c|c|c|c|c|c|c|c|c|}
\hline \multirow{4}{*}{$\begin{array}{l}\text { Dep.var: } \\
\text { log income per } \\
\text { worker in } \\
2000\end{array}$} & \multirow{2}{*}{\multicolumn{2}{|c|}{ Baseline }} & \multicolumn{6}{|c|}{ Share of indigenous people (as of 1500) in current population } \\
\hline & & & \multicolumn{2}{|c|}{0.8} & \multicolumn{2}{|c|}{0.9} & \multicolumn{2}{|c|}{0.95} \\
\hline & OLS & IV & OLS & IV & OLS & IV & OLS & IV \\
\hline & $(1)$ & $(2)$ & (3) & $(4)$ & $(5)$ & $(6)$ & $(7)$ & $(8)$ \\
\hline Individualism & $\begin{array}{l}0.030^{* * * *} \\
(0.003)\end{array}$ & $\begin{array}{l}0.046^{* * *} \\
(0.007)\end{array}$ & $\begin{array}{l}0.040^{* * *} \\
(0.004)\end{array}$ & $\begin{array}{l}0.052^{* * * *} \\
(0.008)\end{array}$ & $\begin{array}{l}0.040^{* * *} \\
(0.005)\end{array}$ & $\begin{array}{l}0.049 * * * \\
(0.009)\end{array}$ & $\begin{array}{l}0.045^{* * * *} \\
(0.005)\end{array}$ & $\begin{array}{l}0.054^{* * * *} \\
(0.011)\end{array}$ \\
\hline Obser & 96 & 96 & 60 & 60 & 46 & 46 & 35 & 35 \\
\hline R-squared & 0.377 & 0.277 & 0.485 & 0.443 & 0.511 & 0.481 & 0.572 & 0.550 \\
\hline 1st stage F-stat & & 45.04 & & 50.77 & & 36.00 & & 19.63 \\
\hline Partial R2 & & 0.341 & & 0.462 & & 0.456 & & 0.431 \\
\hline
\end{tabular}

Notes: the dependent variable is log income (at purchasing power parity) per worker in 2000 from the Penn World Tables. Individualism is Hofstede's index of individualism. A larger value of the index corresponds to a greater level of individualism. The instrument is the Mahalanobis distance of frequency of blood types A and B in a given country relative to the frequency of blood types A and B in the UK. In columns (3) to (8), using the data on migration flows since 1500 from Putterman and Weil (2010), we restrict the sample of countries to those having today a share of people indigenous as of 1500 at the level of more than 80, 90 and 95 percent. Robust standard errors in parentheses. $* * *, * *, *$ denote significance at $0.01,0.05$, and 0.10 levels. 
Table 6. Relative effects of institutions and culture on economic development.

Panel A: Control for protection against expropriation risks.

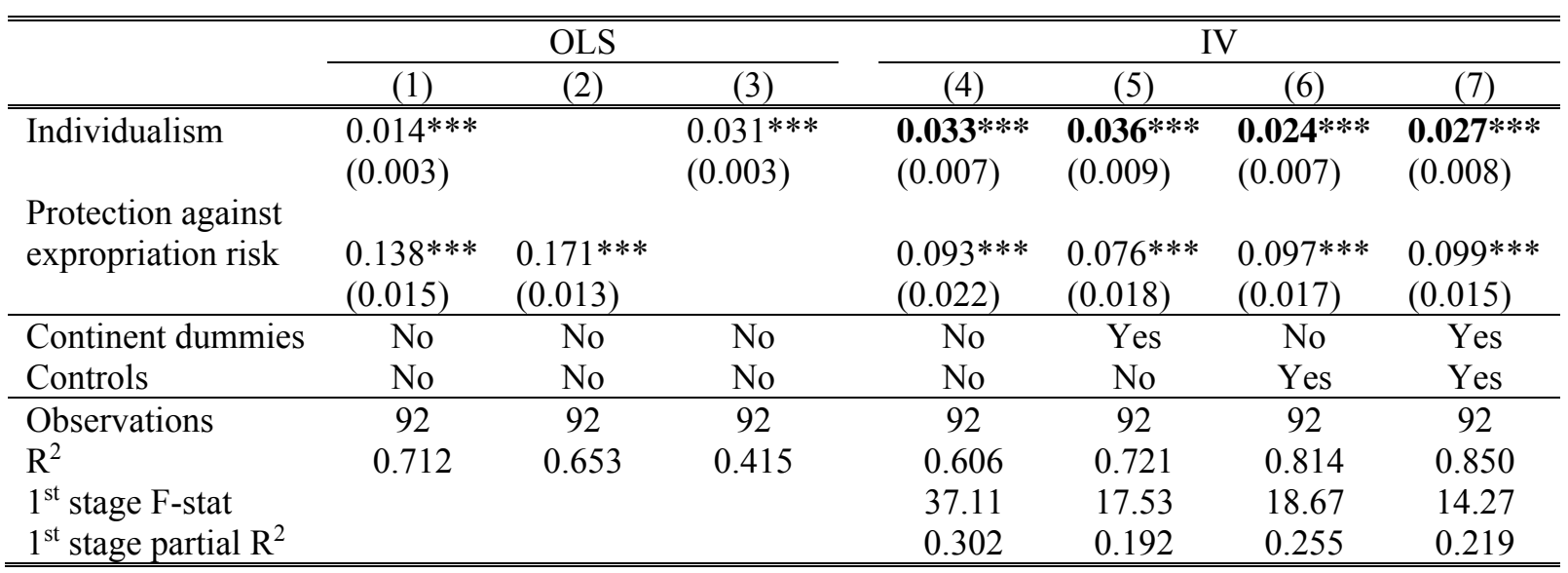

Panel B: Instrument and control for protection against expropriation risks

\begin{tabular}{|c|c|c|c|c|c|c|c|c|}
\hline & \multirow{2}{*}{\multicolumn{3}{|c|}{ OLS }} & \multicolumn{5}{|c|}{ IV } \\
\hline & & & & \multirow{2}{*}{$\begin{array}{c}\text { Blood } \\
\text { Distance } \\
(4)\end{array}$} & \multirow{2}{*}{$\begin{array}{c}\text { Settler } \\
\text { mortality } \\
(5)\end{array}$} & \multirow{2}{*}{$\begin{array}{c}\text { Blood } \\
\text { Distance } \\
+ \\
\text { Settler } \\
\text { mortality }\end{array}$} & \multirow{2}{*}{$\begin{array}{c}\text { Settler } \\
\text { mortality } \\
\text { (Albouy) } \\
(8)\end{array}$} & \multirow{2}{*}{$\begin{array}{c}\text { Blood } \\
\text { Distance } \\
+ \\
\text { Settler } \\
\text { mortality } \\
\text { (Albouy) } \\
(9) \\
\end{array}$} \\
\hline & $(1)$ & (2) & (3) & & & & & \\
\hline Individualism & $\begin{array}{l}0.025 * * * \\
(0.004)\end{array}$ & & $\begin{array}{l}0.009^{*} \\
(0.004)\end{array}$ & $\begin{array}{l}0.045 * * * \\
(0.011)\end{array}$ & & $\begin{array}{l}0.040 * \\
(0.023)\end{array}$ & & $\begin{array}{l}0.039 \\
(0.054)\end{array}$ \\
\hline $\begin{array}{l}\text { Protection against } \\
\text { expropriation risk }\end{array}$ & & $\begin{array}{l}0.222 * * * \\
(0.023)\end{array}$ & $\begin{array}{l}0.195 * * * \\
(0.029)\end{array}$ & & $\begin{array}{l}\mathbf{0 . 3 1 0 * * *} \\
(\mathbf{0 . 0 4 9 )}\end{array}$ & $\begin{array}{l}0.050 \\
(0.165)\end{array}$ & $\begin{array}{l}0.400 * * * \\
(0.121)\end{array}$ & $\begin{array}{l}0.064 \\
(0.548)\end{array}$ \\
\hline Observations & 39 & 39 & 39 & 39 & 39 & 39 & 39 & 39 \\
\hline $\mathrm{R}^{2}$ & 0.281 & 0.602 & 0.630 & 0.094 & 0.507 & 0.257 & 0.215 & 0.294 \\
\hline \multicolumn{9}{|l|}{$1^{\text {st }}$ stage: } \\
\hline \multicolumn{9}{|c|}{ Protection against expropriation risk } \\
\hline F-stat & & & & & 15.41 & 8.668 & 2.720 & 3.522 \\
\hline Partial $\mathrm{R}^{2}$ & & & & & 0.379 & 0.385 & 0.108 & 0.160 \\
\hline \multicolumn{9}{|l|}{ Individualism } \\
\hline F-stat & & & & 10.56 & & 13.50 & & 9.308 \\
\hline Partial $\mathrm{R}^{2}$ & & & & 0.319 & & 0.535 & & 0.423 \\
\hline
\end{tabular}

Notes: the dependent variable is log income (at purchasing power parity) per worker in 2000 from the Penn World Tables. Individualism is Hofstede's index of individualism. A larger value of the index corresponds to a greater level of individualism. Protection against expropriation risk, taken from the International Country Risk Guide, is averaged between 1985 and 2009. It is the same variable Acemoglu et al. (2001) used to approximate the strength of a country's institutions. A larger value of the index corresponds to a greater strength of institutions. The instrument is blood distance, the Mahalanobis distance of frequency of blood types A and B in a given country relative to the frequency of blood types A and B in the U.K. The instrument for institutions (Economic Risk) is Settler mortality from Acemoglu et al. (2001) and Settler mortality (Albouy) from Albouy (2011). The instrumented variables are in bold. Controls include a dummy for landlocked countries, the percentages of population practicing major religions in a country and absolute values of country longitude and latitude. Specifications in Panel B do not include controls. Robust standard errors are in parentheses. $* * *, * * *$ denote significance at $0.01,0.05$, and 0.10 levels. 
Table 7. Effect of individualism after using extended controls.

\begin{tabular}{|c|c|c|c|c|c|c|}
\hline & \multicolumn{2}{|c|}{ Log income per worker } & \multicolumn{2}{|c|}{ Log patents per capita } & \multicolumn{2}{|c|}{$\begin{array}{c}\text { Log TFP } \\
\text { (Hall and Jones, 1999) }\end{array}$} \\
\hline & $\begin{array}{c}\text { OLS } \\
(1)\end{array}$ & $\begin{array}{l}\text { IV } \\
(2)\end{array}$ & $\begin{array}{l}\text { OLS } \\
(3)\end{array}$ & $\begin{array}{l}\text { IV } \\
(4) \\
\end{array}$ & $\begin{array}{c}\text { OLS } \\
(5)\end{array}$ & $\begin{array}{l}\text { IV } \\
(6)\end{array}$ \\
\hline Individualism & $\begin{array}{l}0.012 * * \\
(0.005)\end{array}$ & $\begin{array}{l}0.034 * * * \\
(0.012)\end{array}$ & $\begin{array}{l}0.065^{* * *} \\
(0.019)\end{array}$ & $\begin{array}{l}0.165 * * * \\
(0.046)\end{array}$ & $\begin{array}{l}0.014^{* *} \\
(0.006)\end{array}$ & $\begin{array}{l}0.029 * * * \\
(0.008)\end{array}$ \\
\hline Trust & $\begin{array}{c}0.000 \\
(0.003)\end{array}$ & $\begin{array}{c}0.001 \\
(0.002)\end{array}$ & $\begin{array}{l}-0.002 \\
(0.008)\end{array}$ & $\begin{array}{c}0.002 \\
(0.008)\end{array}$ & $\begin{array}{c}0.002 \\
(0.002)\end{array}$ & $\begin{array}{c}0.002 \\
(0.002)\end{array}$ \\
\hline $\begin{array}{l}\text { Protection against } \\
\text { expropriation risk }\end{array}$ & $0.105 * * *$ & $0.113 * * *$ & $0.427 * * *$ & $0.484 * * *$ & $0.098 * * *$ & $0.111 * * *$ \\
\hline & $(0.016)$ & $(0.014)$ & $(0.061)$ & $(0.077)$ & $(0.020)$ & $(0.018)$ \\
\hline Years of schooling & $\begin{array}{c}0.022 \\
(0.041)\end{array}$ & $\begin{array}{l}-0.047 \\
(0.048)\end{array}$ & $\begin{array}{c}0.196 \\
(0.206)\end{array}$ & $\begin{array}{l}-0.099 \\
(0.237)\end{array}$ & $\begin{array}{l}-0.132 * * \\
(0.054)\end{array}$ & $\begin{array}{l}-0.198 * * * \\
(0.044)\end{array}$ \\
\hline Ethnic fractionalization & $\begin{array}{l}-0.215 \\
(0.320)\end{array}$ & $\begin{array}{l}-0.331 \\
(0.309)\end{array}$ & $\begin{array}{l}-0.954 \\
(0.876)\end{array}$ & $\begin{array}{l}-1.322 \\
(1.052)\end{array}$ & $\begin{array}{l}-0.218 \\
(0.313)\end{array}$ & $\begin{array}{l}-0.163 \\
(0.280)\end{array}$ \\
\hline Legal origin & & & & & & \\
\hline French & $\begin{array}{c}0.214 \\
(0.228)\end{array}$ & $\begin{array}{l}0.329 * \\
(0.192)\end{array}$ & $\begin{array}{c}0.155 \\
(0.566)\end{array}$ & $\begin{array}{c}0.564 \\
(0.454)\end{array}$ & $\begin{array}{c}0.284 \\
(0.194)\end{array}$ & $\begin{array}{l}0.321^{*} \\
(0.164)\end{array}$ \\
\hline German & $\begin{array}{c}0.225 \\
(0.230)\end{array}$ & $\begin{array}{l}0.418^{*} \\
(0.224)\end{array}$ & $\begin{array}{l}1.428^{* *} \\
(0.685)\end{array}$ & $\begin{array}{l}2.358^{* * *} \\
(0.740)\end{array}$ & $\begin{array}{c}0.193 \\
(0.228)\end{array}$ & $\begin{array}{l}0.326^{*} \\
(0.191)\end{array}$ \\
\hline Scandinavian & $\begin{array}{c}0.203 \\
(0.588)\end{array}$ & $\begin{array}{l}0.856 \\
(0.634)\end{array}$ & $\begin{array}{c}0.732 \\
(1.630)\end{array}$ & $\begin{array}{c}2.299 \\
(1.804)\end{array}$ & $\begin{array}{l}-0.041 \\
(0.811)\end{array}$ & $\begin{array}{c}0.174 \\
(0.638)\end{array}$ \\
\hline $\begin{array}{l}\text { Log geographic distance } \\
\text { from the UK }\end{array}$ & $\begin{array}{l}-0.013 \\
(0.205)\end{array}$ & $\begin{array}{c}0.109 \\
(0.180)\end{array}$ & $\begin{array}{c}0.031 \\
(0.446)\end{array}$ & $\begin{array}{c}0.872 \\
(0.589)\end{array}$ & $\begin{array}{l}-0.094 \\
(0.190)\end{array}$ & $\begin{array}{l}-0.023 \\
(0.140)\end{array}$ \\
\hline Share of Europeans 1900 & $\begin{array}{c}0.003 \\
(0.005)\end{array}$ & $\begin{array}{c}0.000 \\
(0.005)\end{array}$ & $\begin{array}{l}-0.035^{* *} \\
(0.013)\end{array}$ & $\begin{array}{l}-0.054^{* * *} \\
(0.017)\end{array}$ & $\begin{array}{c}0.006 \\
(0.005)\end{array}$ & $\begin{array}{c}0.001 \\
(0.005)\end{array}$ \\
\hline Diffusion speed & & & & & & \\
\hline Intensive margin & $\begin{array}{c}0.491 \\
(0.467)\end{array}$ & $\begin{array}{c}0.312 \\
(0.543)\end{array}$ & $\begin{array}{c}3.638 \\
(2.281)\end{array}$ & $\begin{array}{c}4.829^{*} \\
(2.859)\end{array}$ & $\begin{array}{l}1.383 * * \\
(0.592)\end{array}$ & $\begin{array}{l}1.303 * * * \\
(0.455)\end{array}$ \\
\hline Extensive margin & $\begin{array}{c}0.001 \\
(0.008)\end{array}$ & $\begin{array}{l}-0.008 \\
(0.009)\end{array}$ & $\begin{array}{l}-0.016 \\
(0.036)\end{array}$ & $\begin{array}{l}-0.080 \\
(0.050)\end{array}$ & $\begin{array}{l}-0.011 \\
(0.009) \\
\end{array}$ & $\begin{array}{l}-0.018 * * \\
(0.007)\end{array}$ \\
\hline Observations & 74 & 74 & 64 & 64 & 62 & 62 \\
\hline R-squared & 0.914 & 0.873 & 0.928 & 0.851 & 0.869 & 0.841 \\
\hline 1st stage F-stat & & 7.547 & & 6.856 & & 14.230 \\
\hline Partial R2 & & 0.109 & & 0.152 & & 0.294 \\
\hline
\end{tabular}

Notes: the dependent variable is log income (at purchasing power parity) per worker in 2000 from the Penn World Tables. in columns (1) and (2), log patents per million population taken from Economist Intelligence Unit (2007, 2009) in columns (3) and (4), and log total factor productivity (TFP) from Hall and Jones (1999) in columns (5) and (6). Individualism is Hofstede's index of individualism. A larger value of the index corresponds to a greater level of individualism. The instrument is the Mahalanobis distance of frequency of blood types A and B in a given country relative to the frequency of blood types A and B in the UK. Legal origin is from La Porta et al. (1998). British legal origin is the omitted category. Protection against expropriation risk, taken from the International Country Risk Guide, is averaged between 1985 and 2009. It is the same variable Acemoglu et al. (2001) used to approximate the strength of a country's institutions. A larger value of the index corresponds to a greater strength of institutions. Trust is percent of people agreeing that strangers can generally be trusted from the World Values Survey. Years of schooling is the average number of years of schooling for 15+ population in 1970; source: Barro and Lee (2001). Ethnic fractionalization is from Fearon (2003). Geographic distance from the UK is population-weighted distance taken from CEPII database (http://www.cepii.fr/anglaisgraph/bdd/distances.htm). Share of Europeans in 1900 is from Acemoglu et al. (2001). Intensive margin and Extensive margin of technology diffusion are from Comin and Mestieri (2013). All regressions include controls (a dummy for landlocked countries, percentages of population practicing major religions in a country and absolute values of country longitude and latitude) and continent dummies. The instrumented variables are in bold. Robust standard errors are in parentheses. $* * *, * * *$ denote significance at $0.01,0.05$, and 0.10 levels. Estimates on the instrumented variables are statistically significant at least at the $5 \%$ level when inference robust to weak instrumental variables (e.g., Anderson-Rubin) is used. 
Table 8. Culture and institutions.

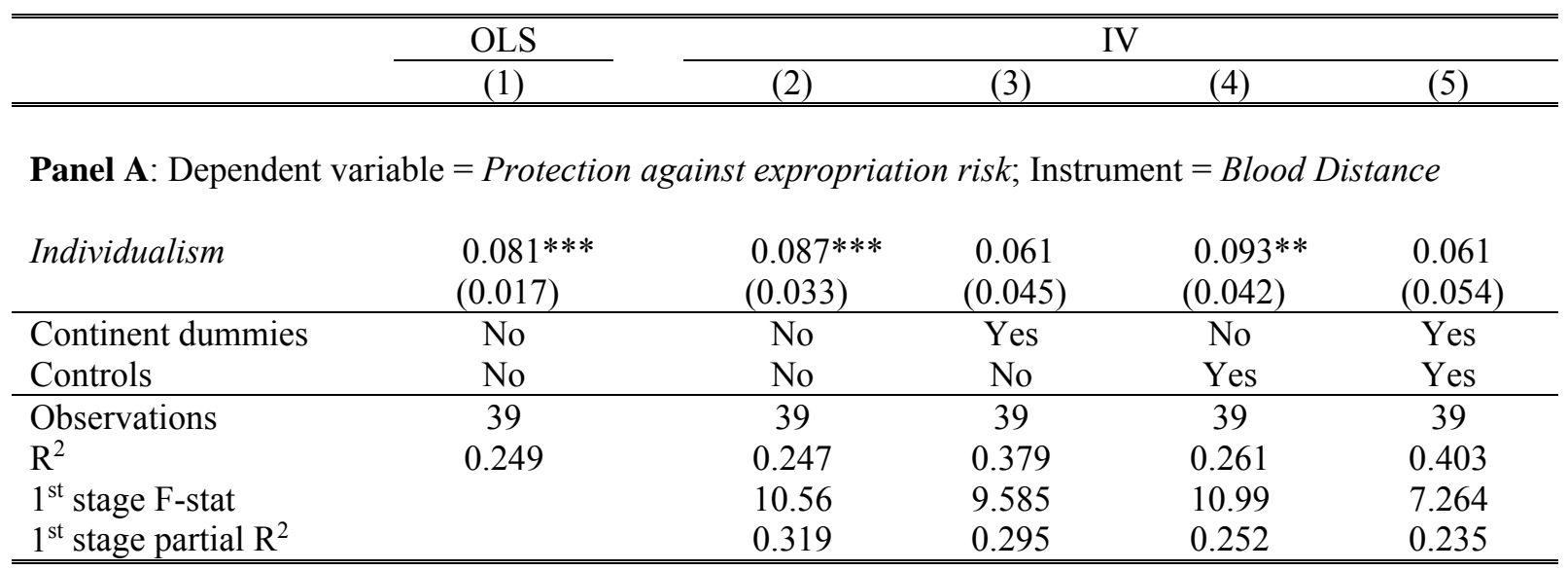

Panel B: Dependent variable = Individualism; Instrument $=$ Setter mortality

\begin{tabular}{lccccc}
$\begin{array}{l}\text { Protection against } \\
\text { expropriation Risk }\end{array}$ & $3.083^{* *}$ & $6.466^{* * *}$ & $7.701^{* * *}$ & $5.696^{* * *}$ & $7.001^{* * *}$ \\
& $(1.155)$ & $(1.622)$ & $(2.467)$ & $(1.773)$ & $(2.471)$ \\
\hline Continent dummies & No & No & Yes & No & Yes \\
Controls & No & No & No & Yes & Yes \\
\hline Observations & 39 & 39 & 39 & 39 & 39 \\
$\mathrm{R}^{2}$ & 0.249 & -0.051 & -0.107 & 0.122 & 0.082 \\
$1^{\text {st }}$ stage F-stat & & 15.41 & 5.170 & 9.157 & 4.054 \\
$1^{\text {st }}$ stage partial $\mathrm{R}^{2}$ & & 0.379 & 0.206 & 0.298 & 0.186 \\
\hline \hline
\end{tabular}

Panel C: Dependent variable $=$ Individualism $;$ Instrument $=$ Setter mortality $($ Albouy $)$

\begin{tabular}{lccccc}
$\begin{array}{l}\text { Protection against } \\
\text { expropriation Risk }\end{array}$ & $3.083^{* *}$ & $8.617^{* *}$ & 12.723 & 8.044 & 11.278 \\
& $(1.155)$ & $(4.115)$ & $(14.101)$ & $(6.616)$ & $(15.585)$ \\
\hline Continent dummies & No & No & Yes & No & Yes \\
Controls & No & No & No & Yes & Yes \\
\hline Observations & 39 & 39 & 39 & 39 & 39 \\
$\mathrm{R}^{2}$ & 0.249 & -0.552 & -1.629 & -0.366 & -1.015 \\
$1^{\text {st }}$ stage F-stat & & 2.720 & 0.495 & 1.115 & 0.313 \\
$1^{\text {st }}$ stage partial $\mathrm{R}^{2}$ & & 0.108 & 0.0271 & 0.0553 & 0.0194 \\
\hline \hline
\end{tabular}

Notes: Individualism is Hofstede's index of individualism. A larger value of the index corresponds to a greater level of individualism. Economic risk is from the International Country Risk Guide which Acemoglu et al. (2001) used to approximate the strength of a country's institutions. A larger value of the index corresponds to a greater strength of institutions. Blood distance is the Mahalanobis distance of frequency of blood types A and B in a given country relative to the frequency of blood types A and B in the UK. The instrument for institutions (Economic Risk) is Settler mortality from Acemoglu et al. (2001) and Settler mortality (Albouy) from Albouy (2011). Controls include a dummy for landlocked countries, and absolute values of country longitude and latitude. Robust standard errors in parentheses. $* * *, * *, *$ denote significance at $0.01,0.05$, and 0.10 levels. 
Table 9. Propensity to choose research-oriented occupations in the USA.

\begin{tabular}{|c|c|c|c|c|}
\hline & \multicolumn{2}{|c|}{2000 U.S. Census } & \multicolumn{2}{|c|}{1970 U.S. Census } \\
\hline & $\begin{array}{l}\text { Persons with } \\
\text { all levels of } \\
\text { education }\end{array}$ & $\begin{array}{c}\text { Persons with } \\
\text { bachelor degree } \\
\text { or higher }\end{array}$ & $\begin{array}{l}\text { Persons with } \\
\text { all levels of } \\
\text { education }\end{array}$ & $\begin{array}{c}\text { Persons with } \\
\text { bachelor degree } \\
\text { or higher }\end{array}$ \\
\hline & (1) & (2) & (4) & (5) \\
\hline \multicolumn{5}{|c|}{ Panel A: U.S. born persons } \\
\hline Individualism & $\begin{array}{l}0.008 * * * \\
(0.002)\end{array}$ & $\begin{array}{l}0.023^{* * *} \\
(0.005)\end{array}$ & $\begin{array}{l}0.011^{* *} \\
(0.005)\end{array}$ & $\begin{array}{l}0.023^{* * *} \\
(0.008)\end{array}$ \\
\hline Observations & 81 & 81 & 61 & 53 \\
\hline R-squared & 0.123 & 0.188 & 0.081 & 0.141 \\
\hline \multicolumn{5}{|c|}{ Panel B: All persons } \\
\hline Individualism & $\begin{array}{l}0.005^{* * *} \\
(0.001)\end{array}$ & $\begin{array}{l}0.016^{* * *} \\
(0.004)\end{array}$ & $\begin{array}{l}0.014 * * * \\
(0.004)\end{array}$ & $\begin{array}{l}0.028^{* * *} \\
(0.007)\end{array}$ \\
\hline Observations & 81 & 81 & 63 & 63 \\
\hline R-squared & 0.131 & 0.181 & 0.130 & 0.209 \\
\hline
\end{tabular}

Notes: The table report Huber-robust estimate of parameter $\theta$ in specification (7). The dependent variable is the set of estimated coefficients $\alpha_{k}$ from regression. Individualism is Hofstede's index of individualism. A larger value of the index corresponds to a greater level of individualism. The definition of research oriented occupations includes Life, Physical, and Social Science Occupations (codes 160-196 in the 2000 census occupational classification system recorded in the IPUMS variable OCC). Ethnicity in the 2000 Census is based on the respondent's self-reported ancestry or ethnic origin (IPUMS variable ANCESTR1). Ethnicity in the 1970 Census is based on the respondent response about father's place of birth (IPUMS variable FBPL). Robust standard errors in parentheses. ***, **, * denote significance at $0.01,0.05$, and 0.10 levels. 
Figure 1. Map of individualism scores.

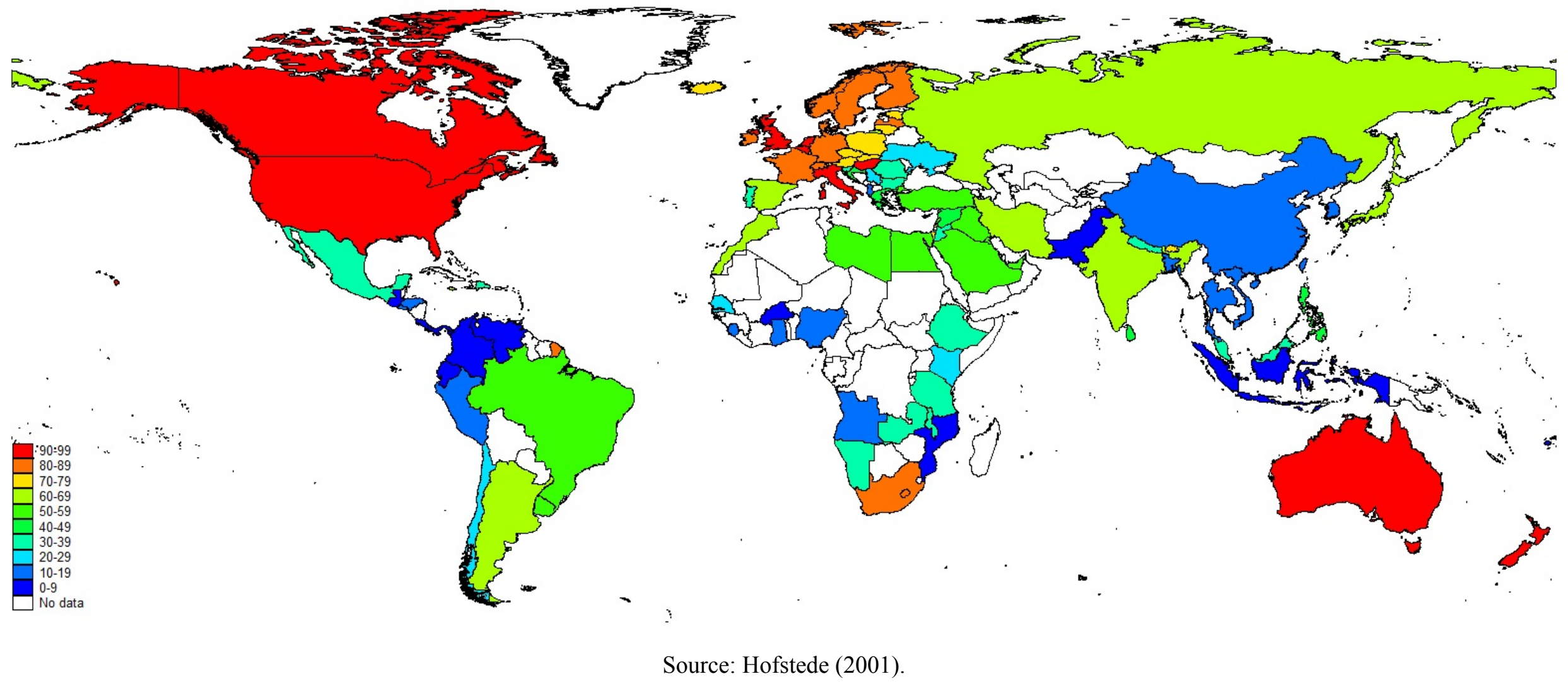


Figure 2. Map of the Mahalanobis distance of frequency of blood types A and $B$ relative to the UK.

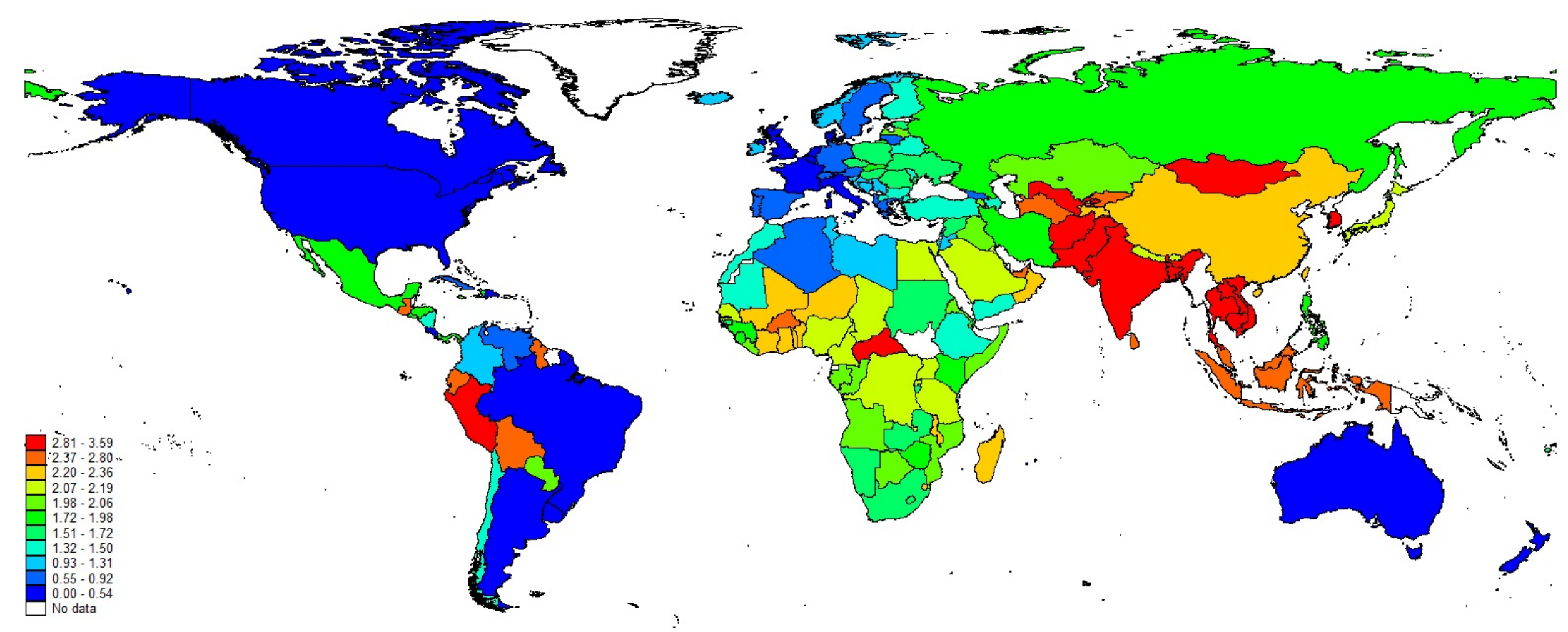


Figure 3. Individualism and economic outcomes.
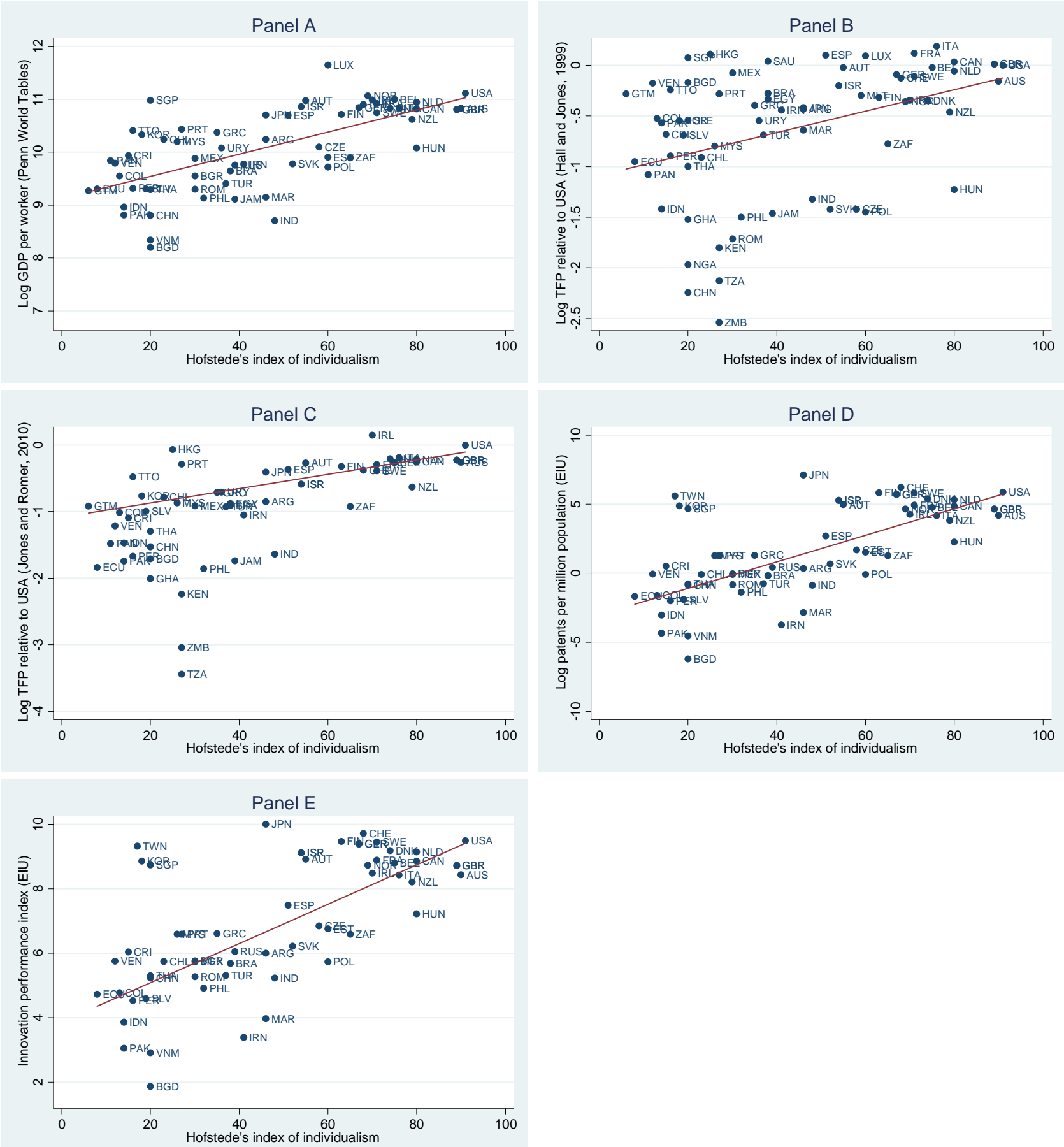

Notes: Individualism is Hofstede's index of individualism. A larger value of the index corresponds to a greater level of individualism. Log income (at purchasing power parity) per worker is from the Penn World Tables. Log total factor productivity relative to the USA is from Hall and Jones (1999) and Jones and Romer (2010). Log patents per million population and innovation performance index are taken from Economist Intelligence Unit (2007, 2009). 
Figure 4. Innovation, income and productivity.
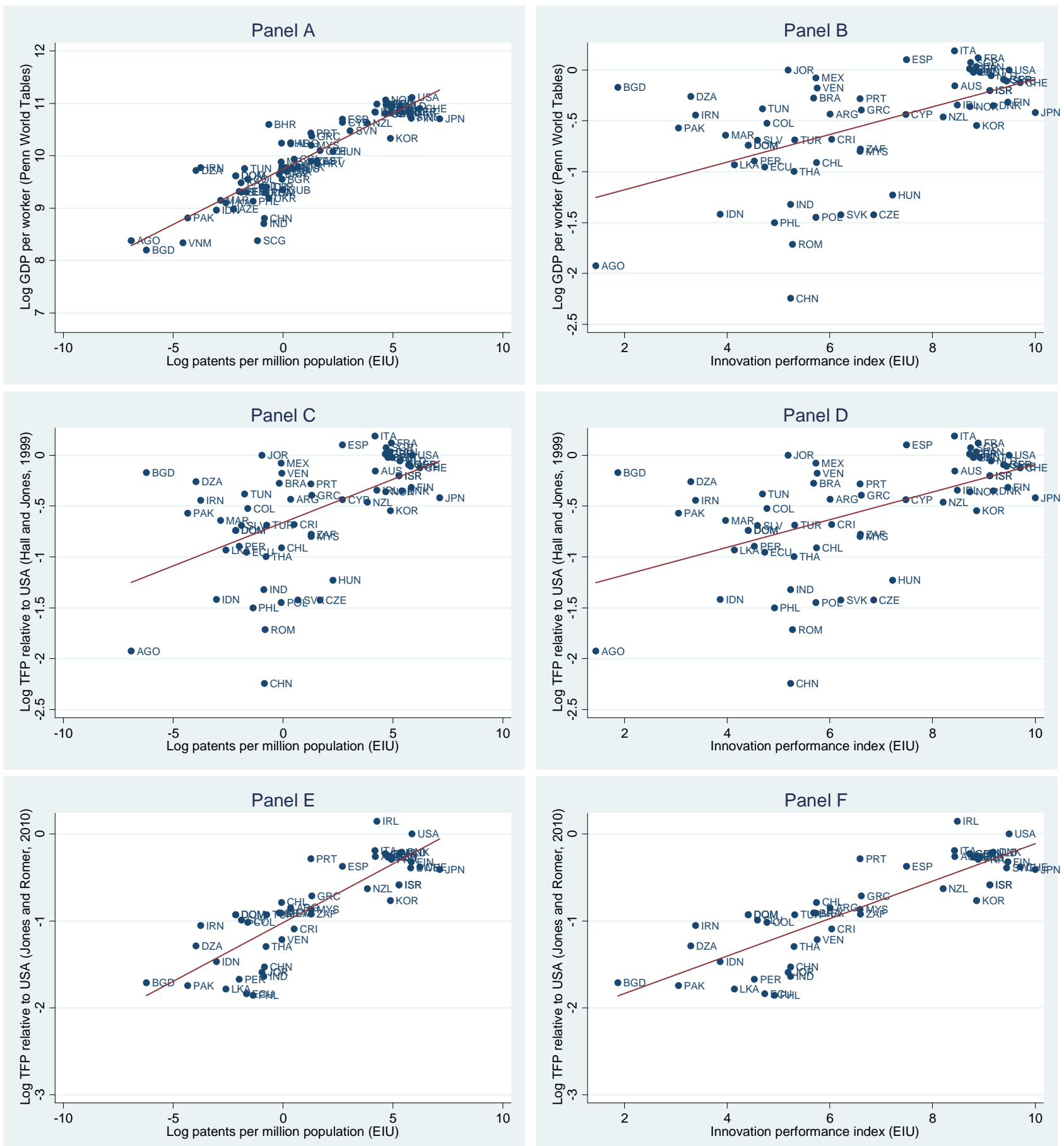

Notes: Log income (at purchasing power parity) per worker is from the Penn World Tables. Log total factor productivity relative to the USA is from Hall and Jones (1999) and Jones and Romer (2010). Log patents per million population and innovation performance index are taken from Economist Intelligence Unit (2007, 2009). 


\section{Figure 5. Individualism and genetic distance}

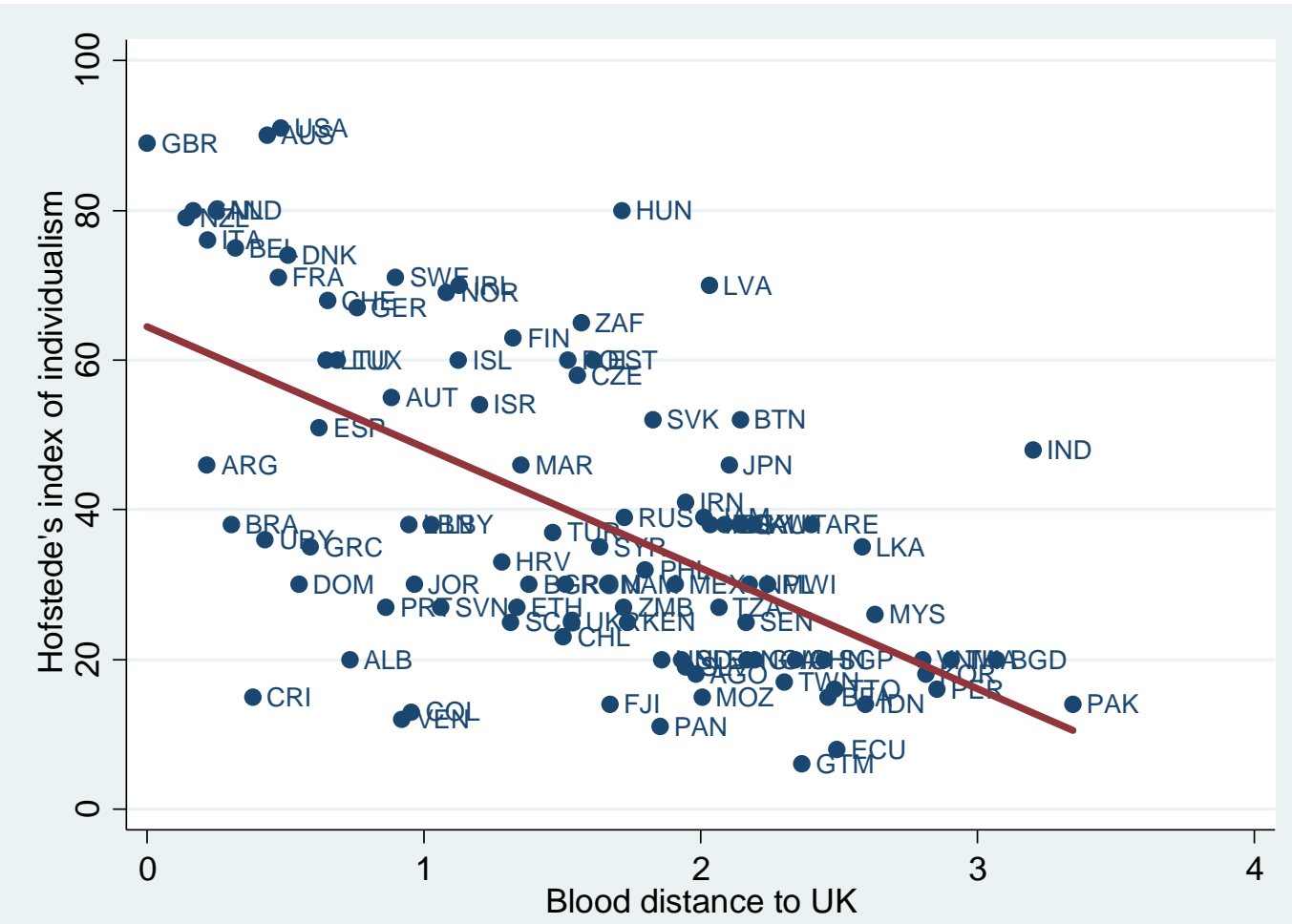

Notes: Individualism is Hofstede's index of individualism. A larger value of the index corresponds to a greater level of individualism. Blood distance to $U K$ is the Mahalanobis distance of frequency of blood types $\mathrm{A}$ and $\mathrm{B}$ in a given country relative to the frequency of blood types A and B in the U.K. 


\section{APPENDIX A}

\section{A model of individualism/collectivism, innovation and economic growth}

Section 2 presents a narrative argument for how individualism can influence innovation and hence economic growth. This appendix develops a model to illustrate how ideas in Section 2 can be formalized. Building blocks in this exercise come from standard frameworks for modeling endogenous economic growth which makes comparison with the previous literature straightforward. Although the model is simple, it can account for a number of empirical regularities and we hope that future research will develop more sophisticated models that combine culture and economic development.

Consider an economy producing two goods: a final good $Y_{t}$ and a continuum of intermediate goods $x_{i t}, i \in[0,1]$. The final good is produced by a competitive sector. Firms in this sector maximize profit

$$
\Pi_{t}=Y_{t}-\int_{0}^{1} p_{i t} x_{i t} d i-w_{t} L_{t}
$$

subject to the production function constraint:

$$
Y_{t}=\eta L_{t}^{1-\alpha} \int_{0}^{1}\left(F_{i t} x_{i t}\right)^{\alpha} d i
$$

where $i$ and $t$ index variety and time, $p_{i t}$ is the price of $x_{i t}, w_{t}$ is the wage rate, $F_{i t}$ is the quality of intermediate good $x_{i t}, L_{t}=\int_{0}^{1} L_{i t} d i$ is aggregate labor input, and $\eta$ is an efficiency parameter measuring how easy it is to combine intermediate inputs. Consistent with the discussion in Section 2, parameter $\eta$ is assumed to be a decreasing function of individualism IND in a given culture, i.e., $\eta=\eta(I N D)$ with $\eta^{\prime}<0$.

Intermediate goods are produced by entrepreneurial households who solve the following optimization problem

$$
\begin{aligned}
& \max \sum_{t=0}^{\infty} \beta^{t}\left(\ln C_{i t}+\phi F_{i t} / F_{t}\right) \\
& \text { subject to } \\
& F_{i t}=\lambda\left(1-L_{i t}\right) F_{i, t-1} \\
& C_{i t}+A_{i t}=\left(1+r_{t}\right) A_{i, t-1}+\Pi_{t}+(1-\tau) \pi_{i t}+w_{t} L_{i t} \\
& \pi_{i t}=p_{i t} x_{i t}-x_{i t}
\end{aligned}
$$

where $F_{t}=\int_{0}^{1} F_{i t} d i$ is the average level of quality of intermediate goods in the economy, $A_{i t}$ is the amount of wealth, $L_{i t}$ is the fraction of labor supply devoted to producing the final goods, $1-L_{t}$ is the fraction of labor supply devoted to research, and $\pi_{i t}$ is the profit from market power in producing an intermediate good. Total labor supply and the marginal cost of producing the intermediate variety are normalized to one for all households.

Equation (A.5) is the standard budget constraint. Equation (A.6) is the profit from producing an intermediate variety. Equation (A.3) is the value function showing that instantaneous utility is derived from consumption goods and from producing a superior than average quality of the intermediate good. The choice of the log utility function for consumption is standard in growth models. It makes the analysis easier as income and substitution effects offset each other and hence it is easy to construct a balanced growth path consistent with the Kaldor facts. The term $\phi F_{i t} / F_{t}$ in the utility function is meant to capture the social status reward from innovation. We assume that $\phi$ is increasing in the level of individualism $I N D$, i.e., $\phi=$ $\phi(I N D)$ with $\phi^{\prime}>0 .{ }^{32}$ Since individual innovating entrepreneurs are small relative to the number of other entrepreneurs in the economy, we assume that an entrepreneur $i$ takes $F_{t}$ as given when deciding how much labor to allocate to research.

Equation (A.4) is the law of motion for the quality of the intermediate good. Quality is a positive function of the labor supply devoted to research. We assume a deterministic law of motion for simplicity only. We also assume that $\lambda(\cdot)$ is an increasing function of the labor supply devoted to research. To simplify the algebra, we assume that the elasticity $\varepsilon=\left(1-L_{i t}\right) \lambda^{\prime}\left(1-L_{i t}\right) / \lambda\left(1-L_{i t}\right)$ is constant in $1-L_{i t}$.

\footnotetext{
${ }^{32}$ Although functions $\phi$ and $\eta$ can be derived from more primitive assumptions potentially entailing restrictions on how $\phi$ and $\eta$ are related to each other, we are agnostic about specific determinants of $\phi$ and $\eta$ and thus allow flexible functional forms for $\phi$ and $\eta$ with minimal restrictions (i.e., $\phi^{\prime}>0$ and $\eta^{\prime}<0$ ).
} 
The government taxes profits of intermediate producers at rate $\tau$ and spends the receipts on (wasteful) consumption $G$ which does not provide any utility to households. ${ }^{33}$

$$
G_{t}=\tau \int_{0}^{1} \pi_{i t} d i
$$

Note that profit $\pi_{i t}$ is the only source of rents in this economy. The tax $\tau$ can also be interpreted as the level of expropriation risk, predatory behavior, lack of rule of law and institutional weakness more generally. We will henceforth interpret high levels of $\tau$ as predatory institutions expropriating rents generated by innovations.

The following equations are market-clearing conditions: equilibrium between aggregate demand and aggregate supply (A.8), equilibrium on the consumer goods market (A.9) and labor market equilibrium (A.10):

$$
\begin{aligned}
& G_{t}+C_{t}=Y_{t} \\
& C_{t}=\int_{0}^{1} C_{i t} d i \\
& L_{t}=\int_{0}^{1} L_{i t} d i
\end{aligned}
$$

Profit maximization in the final good sector implies that

$$
\begin{aligned}
& \frac{\partial \Pi_{t}}{\partial L_{t}}=(1-\alpha) \eta L_{t}^{-\alpha} \int_{0}^{1}\left(F_{i t} x_{i t}\right)^{\alpha} d i-w_{t}=(1-\alpha) Y_{t} / L_{t}-w_{t}=0 \\
& \frac{\partial \Pi_{t}}{\partial x_{i t}}=\alpha \eta L_{t}^{1-\alpha} F_{i t}^{\alpha} x_{i t}^{\alpha-1}-p_{i t}=0
\end{aligned}
$$

Given the demand for the intermediate goods (A.12), the entrepreneurial households' optimality conditions are

$$
\begin{aligned}
& C_{i t}^{-1}=q_{i t} \\
& q_{i t}=\beta\left(1+r_{t+1}\right) q_{i, t+1} \\
& \mu_{i t} \lambda^{\prime}\left(1-L_{i t}\right) F_{i, t-1}=q_{i t} w_{t} \\
& \mu_{i t}=\phi F_{t}^{-1}+q_{i t}(1-\tau) \alpha^{2} \eta L_{i t}^{1-\alpha} F_{i t}^{\alpha-1} x_{i t}^{\alpha}+\beta\left\{\mu_{i, t+1} \lambda\left(1-L_{i, t+1}\right)\right\} \\
& \alpha^{2} \eta L_{t}^{1-\alpha} F_{i t}^{\alpha} x_{i t}^{\alpha-1}=1
\end{aligned}
$$

Equation (A.13) is the standard relationship between consumption $C_{i t}$ and the marginal utility of wealth $q_{i t}$. Equation (A.14) is the Euler equation for consumption. Equation (A.15) captures the instantaneous optimality condition for the allocation of labor to research and production activities. The return on labor has to be equalized between research and the final goods sector. Equation (A.16) is the Euler equation for the quality $F_{i t}$, where $\mu_{i t}$ is the shadow value of $F_{i t}$. The value of a marginal increase in quality (the right hand side of equation on (A.16)) has three components. The first is the social status derived from developing a better technology (the first term on the left hand side). The second is the after-tax marginal revenue product from selling $x_{i t}$ units of the intermediate good of higher quality, and hence facing a larger demand from the final good sector. The third term captures the dynamic gains from better technology. By increasing the level of technology today an entrepreneur prepares the stage for future increases in the level of technology (see equation (A.4)). Equation (A.17) is the first order condition for the level of produced intermediate inputs. It states that the marginal revenue product from producing an additional unit of an intermediate input has to be equal to the marginal cost of producing this additional unit (recall that the marginal cost is normalized to one).

We can then derive the following result in the symmetric equilibrium:

Proposition 1: On a balanced growth path, the ratio of labor devoted to research $1-L$ to labor devoted to producing final goods $L$ is given by:

$$
\frac{1-L}{L}=\left\{\phi+\frac{(1-\tau) \alpha^{2}}{[1-\tau \alpha(1-\alpha)]}\right\} \frac{\varepsilon}{1-\beta} \frac{[1-\tau \alpha(1-\alpha)]}{(1-\alpha)}
$$

The ratio $\frac{1-L}{L}$ is increasing in $\phi$, decreasing in $\tau$, and is independent of $\eta$.

Proof: See below.

\footnotetext{
${ }^{33}$ Our key qualitative results do not change if we allow government spending to be in the form of lump-sum transfers to households or to be an investment in public goods (e.g., infrastructure) which could raise $\eta$. Likewise, our key qualitative results do not change when we also allow status to be derived from the relative level of consumption.
} 
Proposition 1 indicates that the share of labor devoted to research is increasing in the level of individualism $\left(\frac{\partial(1-L) / L}{\partial \phi} \times \frac{\partial \phi}{\partial I N D}>0\right)$ and decreasing in the strength of predatory institutions (larger $\left.\tau\right)$. Intuitively, a higher social status reward to innovation (larger $\phi$ ) increases the allocation of labor to innovation. This culturally embedded incentive to innovate comes on top of the monetary reward to households via higher profits from innovation.

The fact that a high level of predatory institutions (larger $\tau$ ) has a negative effect on innovation is less novel. Note that the latter effect is due to the fact that taxes are levied directly on the profit from intermediate goods so that $\tau$ directly affects the incentive to innovate. If taxation were on final output, its distortionary effect on innovation would be absent and would affect only levels of variables. ${ }^{34}$

Note also that the cost of individualism captured by a low value of $\eta$ only affects the level of output for any given average quality of intermediate input, but not the rate of innovation. Indeed, parameter $\eta$ is not present in equation (A.18). Intuitively, a higher level of $\eta$ will lead to the same proportional increase in the equilibrium level of intermediate output and equilibrium level of final output. Since returns to labor in the research and final good sector are equalized, changes in $\eta$ do not affect the equilibrium level of allocation of labor between research and the final good sector.

The proposition also states that the negative effect of taxes on research effort becomes smaller when the status derived from research effort increases. In other words, high status rewards can counteract high tax rates because while income and wealth can be expropriated, social status cannot. ${ }^{35}$ Our model shows that the negative effect of predatory institutions on long-run growth can be offset by the social status reward to innovation under an individualist culture. Note also that $\lim _{\tau \rightarrow 1} \frac{1-L}{L}=\phi \frac{\varepsilon}{1-\beta} \frac{[1-\alpha(1-\alpha)]}{(1-\alpha)}$ and thus, if $\phi=0$, no labor is devoted to research when institutions are fully predatory. In other words, if culture were absent in this model, predatory institutions would result in lack of innovation. With zero research effort, the growth rate in the economy is also equal to zero.

We now turn to the properties of the economy on the balanced growth path. First, from equation (A.4) on a balanced growth path we get that $\gamma_{F} \equiv \frac{F_{t}}{F_{t-1}}=\lambda(1-L)$ and consequently $\operatorname{sgn}\left(\frac{\partial \gamma_{F}}{\partial \phi}\right)=$ $\operatorname{sgn}\left(\frac{\partial(1-L) / L}{\partial \phi}\right)$ and $\operatorname{sgn}\left(\frac{\partial \gamma_{F}}{\partial \tau}\right)=\operatorname{sgn}\left(\frac{\partial(1-L) / L}{\partial \tau}\right)$. Also observe that the level of total factor productivity (TFP) in the final goods sector is $T F P_{t}=\eta F_{t}^{\alpha}$ which varies over time only due to changes in $F_{t}$ as we assume fixed cultural attributes. The results of Proposition 1 thus carry over to the growth rate of TFP, which will be higher for more individualist cultures and for lower levels of taxation.

Along a balanced path in a symmetrical equilibrium, $Y_{t}=\eta L^{1-\alpha} F_{t}^{\alpha} x_{t}^{\alpha}$. Using equation (A.17), we get $x_{t}=\alpha^{2} Y_{t}$ so that $Y_{t}=\left(\eta \alpha^{2 \alpha}\right)^{1 /(1-\alpha)} L F_{t}^{\alpha /(1-\alpha)}$ and therefore $\gamma_{Y} \equiv Y_{t} / Y_{t-1}=\gamma_{F}^{\alpha /(1-\alpha)}$. We conclude that the growth rate of output in the economy is determined by the growth rate of technology, which is pinned down by rewards to innovation. From equation (A.11), we have $\gamma_{w} \equiv w_{t} / w_{t-1}=\gamma_{Y}$. Given that $x_{t}=\alpha^{2} Y_{t}$ and equations (A.6), (A.7), and (A.8), we have $C_{t}=Y_{t}-G_{t}=[1-\tau \alpha(1-\alpha)] Y_{t}$. Therefore, $\gamma_{C} \equiv C_{t} / C_{t-1}=\gamma_{Y}$ and income, consumption and wages grow at the same rate. From (A.14) and (A.13), we have $r_{t}=\left(C_{t+1} / C_{t}\right) / \beta-1=\gamma_{C} / \beta-1$ and thus the interest rate is constant. Finally, note that the value of capital, which is equal to the present value of profits generated in the intermediate goods sector, is proportional to output and hence the capital-output ratio is constant on the balanced growth path. These last results show that the model fits the Kaldor facts about economic growth. ${ }^{36}$

\footnotetext{
${ }^{34}$ Note that profits in the final goods sector are equal to zero in equilibrium and cannot be a source of taxation. If labor income were taxed instead, there would be a positive effect of $\tau$ on innovation.

${ }^{35}$ One can argue that predatory institutions and individualist culture should not coexist easily and that under an individualist culture, there will eventually be strong pressures to reform political institutions so as to limit the executive powers of government. This would point towards a causal effect from culture to institutions. This observation is discussed in the empirical section. See also Roland (2004).

${ }^{36}$ Similar to other models of endogenous growth, our model implies that countries should have permanently different growth rates and thus continuously increasing income differences. Although there is a variety of modifications (e.g., semi-endogenous growth) employed in the literature to correct for this probably counterfactual prediction, we do not
} 
We may use this framework to model the reversal of fortunes discussed in Section 2. One may characterize the Malthusian stage as a state of the economy where no resources are allocated to the entrepreneurial sector. This state may arise because, for example, life expectancy is too short in the Malthusian stage to capitalize innovation in monetary or status-based form and incentives to innovate are weak. In this stage, the advantage of an individualist culture (higher $\phi$ ) is mute, while the advantage of a collectivist culture (higher $\eta$ ) is present. As a result, a collectivist culture has a higher income per capita than an individualistic culture in the Malthusian stage because it is more effective at combining intermediate inputs. However, when an economy exits the Malthusian stage due to a technical, climatic or some other change and a positive share of population is allocated to the entrepreneurial sector, an individualistic culture generates a growth rate faster than that of a collectivist culture and eventually output per capita in an individualistic culture overtakes output per capita in a collectivist culture.

\section{Proof of proposition 1:}

In the symmetric equilibrium we have

$Y_{t}=\eta L_{t}^{1-\alpha} F_{t}^{\alpha} x_{t}^{\alpha}$,

$p_{t}=\alpha \eta L_{t}^{1-\alpha} F_{t}^{\alpha} x_{t}^{\alpha-1}=\alpha^{-1}$,

$w_{t}=(1-\alpha) Y_{t} / L_{t}$,

$x_{t}=\alpha^{2} \eta L_{t}^{1-\alpha} F_{t}^{\alpha} x_{t}^{\alpha}=\alpha^{2} Y_{t}$,

$\pi_{t}=p_{t} x_{t}-x_{t}=\alpha(1-\alpha) Y_{t}$,

$G_{t}=\tau \alpha(1-\alpha) Y_{t}$

$C_{t}=Y_{t}-G_{t}=[1-\tau \alpha(1-\alpha)] Y_{t}$,

$1 / C_{t}=q_{t}$,

$q_{t}=\beta\left(1+r_{t+1}\right) q_{t+1}$,

$\mu_{t} \lambda^{\prime}\left(1-L_{t}\right) F_{t-1}=q_{t} w_{t}$,

$\mu_{t}=\phi F_{t}^{-1}+\beta\left\{\mu_{t+1} \lambda\left(1-L_{t+1}\right)\right\}+q_{t}(1-\tau) \alpha^{2} \eta L_{t}^{1-\alpha} F_{t}^{\alpha-1} x_{t}^{\alpha}$,

$\alpha^{2} \eta L_{t}^{1-\alpha} F_{t}^{\alpha} x_{t}^{\alpha-1}=1$,

$F_{t}=\lambda\left(1-L_{t}\right) F_{t-1}$.

Using (A.21), (A.26) and (A.28), we have

$\mu_{t}=\frac{1}{\lambda^{\prime}\left(1-L_{t}\right)} \frac{1}{F_{t-1}} \frac{w_{t}}{C_{t}}=\frac{1}{\lambda^{\prime}\left(1-L_{t}\right)} \frac{1}{F_{t-1}} \frac{(1-\alpha) Y_{t} / L_{t}}{[1-\tau \alpha(1-\alpha)] Y_{t}}=\frac{1}{L_{t} \lambda^{\prime}\left(1-L_{t}\right)} \frac{1}{F_{t-1}} \frac{(1-\alpha)}{[1-\tau \alpha(1-\alpha)]}$.

Plug this expression for $\mu_{t}$ into (A.29) and simplify to find

$$
\begin{aligned}
& \frac{(1-\alpha)}{[1-\tau \alpha(1-\alpha)]} \frac{1-L_{t}}{L_{t}} \frac{\lambda\left(1-L_{t}\right)}{\left(1-L_{t}\right) \lambda\left(1-L_{t}\right)} \lambda^{\prime}\left(1-L_{t}\right) \frac{F_{t}}{F_{t-1}} \\
& =\phi+\beta\left\{\frac{(1-\alpha)}{[1-\tau \alpha(1-\alpha)]} \frac{1-L_{t+1}}{L_{t+1}} \frac{\lambda\left(1-L_{t+1}\right)}{\left(1-L_{t+1}\right) \lambda_{\prime}\left(1-L_{t+1}\right)}\right\}+\frac{(1-\tau) \alpha^{2}}{[1-\tau \alpha(1-\alpha)]} .
\end{aligned}
$$

Given $\varepsilon=\left(1-L_{i t}\right) \lambda^{\prime}\left(1-L_{i t}\right) / \lambda\left(1-L_{i t}\right)$ and (A.31), we can further simplify to

$\frac{(1-\alpha)}{[1-\tau \alpha(1-\alpha)]} \frac{1-L_{t}}{L_{t}} \frac{1}{\varepsilon}=\phi+\beta\left\{\frac{(1-\alpha)}{[1-\tau \alpha(1-\alpha)]} \frac{1-L_{t+1}}{L_{t+1}} \frac{1}{\varepsilon}\right\}+\frac{(1-\tau) \alpha^{2}}{[1-\tau \alpha(1-\alpha)]}$.

On a balanced growth path, we have $L_{t}=L$ and thus

$\frac{1-L}{L}=\left\{\phi+\frac{(1-\tau) \alpha^{2}}{[1-\tau \alpha(1-\alpha)]}\right\} \frac{\varepsilon}{1-\beta} \frac{[1-\tau \alpha(1-\alpha)]}{(1-\alpha)}$

Note that $\frac{1-L}{L}$ is monotonically decreasing in $L$. We can then derive:

incorporate these modifications in our model to keep the logic as concise and clear as possible. One can however anticipate that, for example, if we allow for diffusion of technology from leaders to laggers, the distribution of income differences with be stationary with leaders (more innovative countries) being richer since they are technologically a few steps ahead of laggers. 


$$
\frac{\partial\left(\frac{1-L}{L}\right)}{\partial \phi}=\frac{\varepsilon}{1-\beta} \frac{[1-\tau \alpha(1-\alpha)]}{(1-\alpha)}>0, \frac{\partial\left(\frac{1-L}{L}\right)}{\partial \tau}=-\frac{\varepsilon \alpha}{1-\beta}(\alpha+\phi)<0, \frac{\partial\left(\frac{1-L}{L}\right)}{\partial \eta}=0 .
$$




\section{APPENDIX B}

\section{The downward bias on an instrumented variable when several variables need to be instrumented.}

Suppose that the link between economic variable $Y$, culture $C$ and institutions $I$ is given by the following setup

$$
\begin{aligned}
& Y=\alpha C+\beta I+\varepsilon \\
& C=D+u \\
& I=Q+e
\end{aligned}
$$

where equation (B.1) shows the effect of culture and institutions on economic outcomes (e.g., income per worker), equation (B.2) captures the first-stage for culture with $D$ being exogenous genetic distance, equation (B.3) reflects the first stage regression for institutions with $Q$ being exogenous (to economic outcomes) factors affecting the spread of institutions. We assume that

$\alpha>0, \beta>0$ which means that culture and institutions both positively affect economic outcomes,

$\operatorname{cov}(D, Q)>0$ which means that factors affecting the spread of culture and institutions (or similar factors) are positively correlated,

$\operatorname{cov}(\varepsilon, u)>0, \operatorname{cov}(\varepsilon, e)>0, \operatorname{cov}(u, e)>0$ which captures the endogeneity of culture and institutions.

The positive correlations mean that unobservables move economic outcomes, institutions and culture in the same direction.

We have a good instrument for culture (i.e., $D$ ) but for variables that measure institutions (or maybe other factors such as trust, rule of law, etc.) it may be hard to come by a good instrument which has a good coverage of countries. For example, settle mortality applies only to colonies and excludes European countries. Hence, the question is what would happen with an estimate of $\alpha$ if we instrument only culture.

Using the facts that $\hat{\gamma}^{I V}=\left[\begin{array}{ll}\hat{\alpha}^{I V} & \hat{\beta}^{I V}\end{array}\right]=\left(Z^{\prime} X\right)^{-1}\left(Z^{\prime} Y\right)$, we can show that if $Z=\left[\begin{array}{ll}D & I\end{array}\right]$ (rather than $\left.Z=\left[\begin{array}{ll}D & Q\end{array}\right]\right)$ then

$$
\hat{\alpha}^{I V}=\alpha-\frac{[\beta \operatorname{var}(I)+\operatorname{cov}(e, \varepsilon)] \operatorname{cov}(D, Q)}{\operatorname{var}(D) \operatorname{var}(Q)\left(1-\rho_{D Q}^{2}\right)+\operatorname{var}(D) \operatorname{var}(e)\left(1-\rho_{D Q} \rho_{u e} \sqrt{\frac{\left(1-R_{C D}^{2}\right) / R_{C D}^{2}}{\left(1-R_{I Q}^{2}\right) / R_{I Q}^{2}}}\right)}
$$

where $\rho_{D Q}=\frac{\operatorname{cov}(D, Q)}{\sqrt{\operatorname{var}(D) \operatorname{var}(Q)}}, \rho_{u e}=\frac{\operatorname{cov}(u, e)}{\sqrt{\operatorname{var}(u) \operatorname{var}(e)}}, R_{C D}^{2}$ is the $\mathrm{R}^{2}$ in equation (B.2), $R_{I Q}^{2}$ is the $\mathrm{R}^{2}$ in equation (B.3).

The numerator in the bias term in equation (B.4) is unambiguously positive. The sign of the denominator depends on the strength of correlations between error terms as well as correlation between $D$ and $Q$ and the relative strength of the fit in the first stage regressions (B.2) and (B.3). We can assess empirically if this term is positive when we use genetic distance and settler mortality as instrumental variables. Specifically, the $\mathrm{R}^{2}$ is the first stage fit is about $0.2-0.3$ in both regressions (B.2) and (B.3) so that the range for $\sqrt{\frac{\left(1-R_{C D}^{2}\right) / R_{C D}^{2}}{\left(1-R_{I Q}^{2}\right) / R_{I Q}^{2}}}$ is 0.5 to 1.5 at most. The correlation between error terms in the first stage is 0.3 . The correlation between predicted values of $C$ and $I$ (which correspond to $D$ and $Q$ ) is 0.1 . Hence, the bias in unambiguously downward.

To conclude, if we do not instrument institutions or any other variable which satisfies conditions we spell out above, we would have a negative bias in the estimates. If the bias is downward and we still find a positive and significant value of $\hat{\alpha}^{I V}$, then the true value of $\alpha$ has to be even larger. 


\section{APPENDIX C}

Questions from Hofstede's survey used to identify individualism (source Exhibit 5.11 in Hofstede (2001)):

1. Have challenging work to do - work from which you can get a personal sense of accomplishment [challenge].

2. Live in an area desirable to you and your family [desirable area].

3. Have an opportunity of high earnings [earnings].

4. Work with people who cooperate well with one another [cooperation].

5. Have training opportunities (to improve your skills and to learn new skills) [training].

6. Have good fringe benefits [benefits].

7. Get recognition you deserve when you do a good job [recognition].

8. Have good physical working conditions (good ventilation and lighting, adequate work space, etc.) [physical conditions].

9. Have considerable freedom to adapt your own approach to the job [freedom].

10. Have the security that you will be able to work for your company as long as you want to [employment security].

11. Have an opportunity for advancement to higher level jobs [advancement].

12. Have a good working relationship with your manager [manager].

13. Fully use your skills and abilities on the job [use of skills].

14. Have a job which leaves you sufficient time for your personal or family life [personal time].

15. Have the security that you will not be transferred to a less desirable job [position security].

16. Work in a department which is run efficiently [efficient department].

17. Have a job which allows you to make a real contribution to the success of your company [contribute to company].

18. Work in a company which is regarded in your country as successful [successful company].

19. Work in a company which stands in the forefront of modern technology [modern company].

20. Work in a congenial and friendly atmosphere [friendly atmosphere].

21. Keep up to date with the technical developments relating to your work [up-to-dateness].

22. Have a job on which there is a great deal of day-to-day learning [day-to-day learning].

23. Have little tension and stress on the job [stress-free].

24. Be consulted by your direct supervisor in his/her decisions [consulted].

25. Make a real contribution to the success of your company or organization [contribute].

26. Serve your country [country].

27. Have an element of variety and adventure in the job [variety].

28. Work in a prestigious, successful company or organization [prestige].

29. Have an opportunity for helping other people [helping].

30. Work in a well-defined job situation where requirement are clear [clear job]. 


\section{APPENDIX D: Additional Tables and Figures}

Appendix Table D1. Descriptive statistics.

\begin{tabular}{|c|c|c|c|c|c|}
\hline Variable & Obs & Mean & Std. Dev. & Min & Max \\
\hline \multicolumn{6}{|l|}{ Explanatory variables } \\
\hline Individualism & 78 & 41.717 & 22.980 & 6 & 91 \\
\hline Trust & 114 & 51.453 & 28.210 & 7.900 & 148 \\
\hline Education index & 147 & 0.764 & 0.197 & 0.118 & 0.993 \\
\hline Ethnic fractionalization & 152 & 0.470 & 0.258 & 0.002 & 1 \\
\hline Log geographic distance from the UK & 164 & 8.426 & 0.812 & 5.382 & 9.826 \\
\hline Protection against expropriation risk & 138 & 33.728 & 5.777 & 16.5 & 44.96 \\
\hline \multicolumn{6}{|l|}{ Instrumental variables } \\
\hline Pronoun drop & 41 & .560 & 0.502 & 0 & 1 \\
\hline Euclidian genetic distance from the USA & 156 & 0.086 & 0.038 & 0 & 0.185 \\
\hline Mahalanobis genetic distance from the USA & 156 & 1.504 & 0.660 & 0 & 3.163 \\
\hline Euclidian genetic distance from the UK & 156 & 0.102 & 0.048 & 0 & 0.212 \\
\hline Mahalanobis genetic distance from the UK & 156 & 1.752 & 0.809 & 0 & 3.586 \\
\hline \multicolumn{6}{|l|}{ Economic outcome variables } \\
\hline Log income per worker & 153 & 9.246 & 1.187 & 6.785 & 11.648 \\
\hline Log patents per million of population & 81 & 0.705 & 3.363 & -7.600 & 7.126 \\
\hline Innovation performance index & 81 & 6.224 & 2.107 & 1.440 & 10 \\
\hline \multicolumn{6}{|l|}{ Log TFP relative to the USA } \\
\hline Hall and Jones (1999) & 117 & -0.893 & 0.713 & -2.538 & 0.188 \\
\hline Jones and Romer (2010) & 79 & -1.199 & 0.799 & -3.440 & 0.146 \\
\hline
\end{tabular}


Appendix Table D2. Long-term growth, 1500-2001 and 1820-2001.

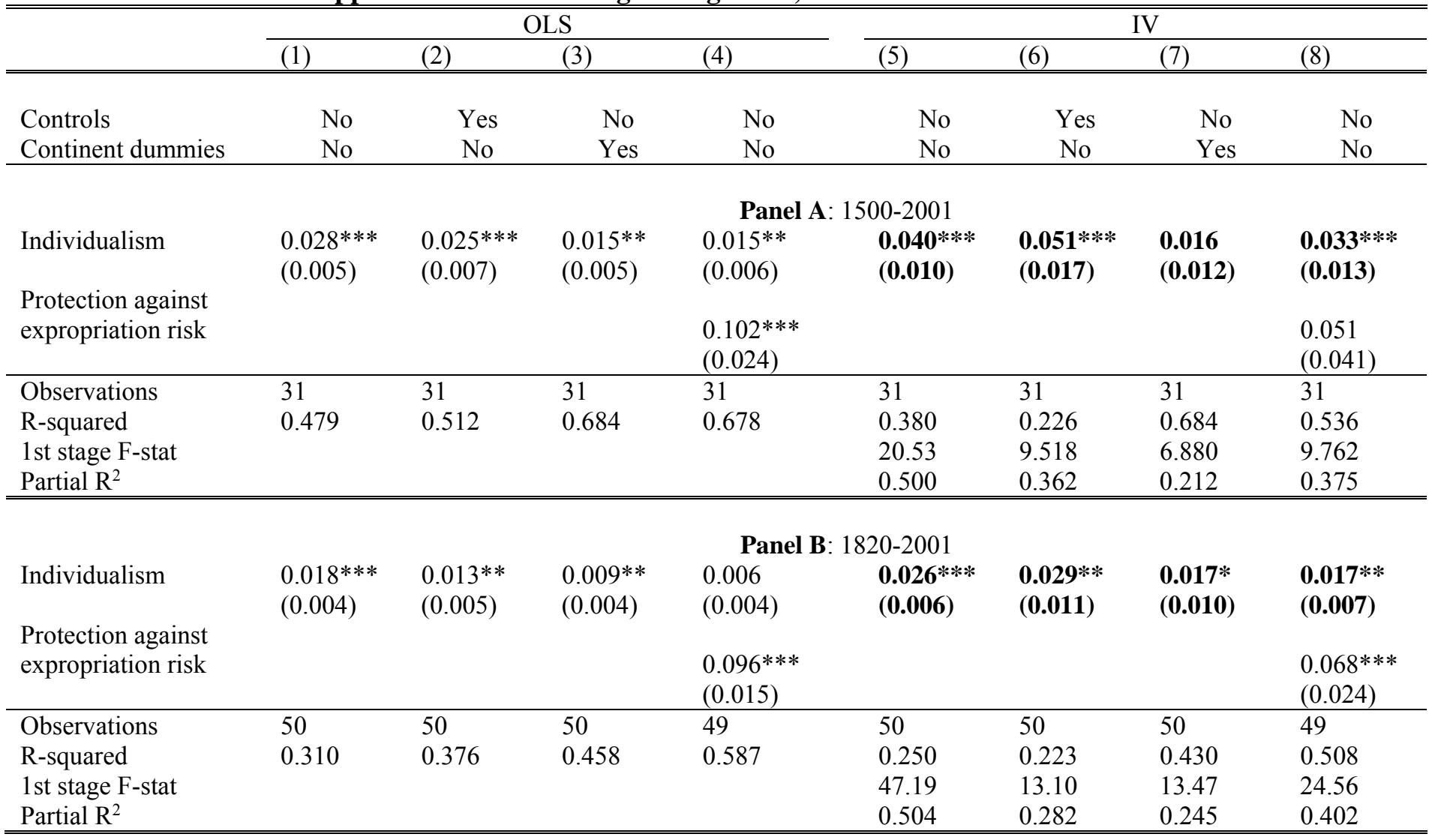

Notes: the dependent variable is $\log$ growth rate of income per capita from Maddison (2003). Individualism is Hofstede's index of individualism. The instrument is the Mahalanobis distance of frequency of blood types A and B in a given country relative to the frequency of blood types A and B in the U.K. Protection against expropriation risk, taken from the International Country Risk Guide, is averaged between 1985 and 2009. It is the same variable Acemoglu et al. (2001) used to approximate the strength of a country's institutions. A larger value of the index corresponds to a greater strength of institutions. The instrumented variables are in bold. Controls include a dummy for landlocked countries, the percentages of population practicing major religions in a country and absolute values of country longitude and latitude. Robust standard errors in parentheses. ${ }^{* * *}, * *, *$ denote significance at $0.01,0.05$, and 0.10 levels. 


\section{Appendix Table D3. Relative effects of institutions and culture on log patents per capita.}

Panel A: Control for protection against expropriation risks.

\begin{tabular}{|c|c|c|c|c|c|c|c|}
\hline & \multicolumn{3}{|c|}{ OLS } & \multicolumn{4}{|c|}{ IV } \\
\hline & (1) & (2) & (3) & (4) & (5) & (6) & (7) \\
\hline Individualism & $\begin{array}{l}0.059 * * * \\
(0.011)\end{array}$ & & $\begin{array}{l}0.098 * * * \\
(0.012)\end{array}$ & $\begin{array}{l}0.106 * * * \\
(0.025)\end{array}$ & $\begin{array}{l}0.103 * * * \\
(0.037)\end{array}$ & $\begin{array}{l}0.105^{* * *} \\
(0.035)\end{array}$ & $\begin{array}{l}0.102 * * * \\
(0.031)\end{array}$ \\
\hline $\begin{array}{l}\text { Protection against } \\
\text { expropriation risk }\end{array}$ & $\begin{array}{l}0.412^{* * *} \\
(0.077)\end{array}$ & $\begin{array}{l}0.569 * * * \\
(0.071)\end{array}$ & & $\begin{array}{l}0.289 * * * \\
(0.109)\end{array}$ & $\begin{array}{l}0.279 * * \\
(0.112) \\
\end{array}$ & $\begin{array}{l}0.315^{* * *} \\
(0.075)\end{array}$ & $\begin{array}{l}0.313^{* * *} \\
(0.062)\end{array}$ \\
\hline Continent dummies & No & No & No & No & Yes & No & Yes \\
\hline Controls & No & No & No & No & No & Yes & Yes \\
\hline Observations & 71 & 71 & 71 & 71 & 71 & 71 & 71 \\
\hline $\mathrm{R}^{2}$ & 0.641 & 0.521 & 0.435 & 0.566 & 0.670 & 0.796 & 0.847 \\
\hline $1^{\text {st }}$ stage F-stat & & & & 31.14 & 11.73 & 12.07 & 10.42 \\
\hline $1^{\text {st }}$ stage partial $R^{2}$ & & & & 0.317 & 0.135 & 0.224 & 0.191 \\
\hline
\end{tabular}

Panel B: Instrument and control for protection against expropriation risks

\begin{tabular}{|c|c|c|c|c|c|c|c|c|}
\hline & \multirow{2}{*}{\multicolumn{3}{|c|}{ OLS }} & \multicolumn{5}{|c|}{ IV } \\
\hline & & & & $\begin{array}{l}\text { Blood } \\
\text { Distance }\end{array}$ & $\begin{array}{l}\text { Settler } \\
\text { mortality }\end{array}$ & $\begin{array}{c}\text { Blood } \\
\text { Distance } \\
+ \\
\text { Settler } \\
\text { mortality }\end{array}$ & $\begin{array}{c}\text { Settler } \\
\text { mortality } \\
\text { (Albouy) }\end{array}$ & $\begin{array}{c}\text { Blood } \\
\text { Distance } \\
+ \\
\text { Settler } \\
\text { mortality } \\
\text { (Albouy) }\end{array}$ \\
\hline & $(1)$ & (2) & (3) & (4) & (5) & (7) & $(8)$ & (9) \\
\hline Individualism & $\begin{array}{l}0.097 * * * \\
(0.013)\end{array}$ & & $\begin{array}{l}0.063 * * * \\
(0.014)\end{array}$ & $\begin{array}{l}0.158 * * * \\
(0.033)\end{array}$ & & $\begin{array}{l}0.197 \\
(0.141)\end{array}$ & & $\begin{array}{l}0.233 \\
(0.197)\end{array}$ \\
\hline $\begin{array}{l}\text { Protection against } \\
\text { expropriation risk }\end{array}$ & & $\begin{array}{l}0.717 * * * \\
(0.124)\end{array}$ & $\begin{array}{l}0.410^{* * *} \\
(0.092)\end{array}$ & & $\begin{array}{l}1.033^{* * *} \\
(0.148)\end{array}$ & $\begin{array}{l}-0.430 \\
(1.170)\end{array}$ & $\begin{array}{l}0.964 * * * \\
(0.155)\end{array}$ & $\begin{array}{l}-0.823 \\
(1.684)\end{array}$ \\
\hline Observations & 27 & 27 & 27 & 27 & 27 & 27 & 27 & 27 \\
\hline $\mathrm{R}^{2}$ & 0.586 & 0.546 & 0.692 & 0.357 & 0.440 & -0.008 & 0.481 & -0.546 \\
\hline \multicolumn{9}{|l|}{$1^{\text {st }}$ stage: } \\
\hline \multicolumn{9}{|c|}{ Protection against expropriation risk } \\
\hline F-stat & & & & & 12.89 & 8.548 & 12.81 & 8.460 \\
\hline Partial $\mathrm{R}^{2}$ & & & & & 0.498 & 0.520 & 0.474 & 0.499 \\
\hline \multicolumn{9}{|l|}{ Individualism } \\
\hline F-stat & & & & 9.124 & & 11.74 & & 11.43 \\
\hline Partial $\mathrm{R}^{2}$ & & & & 0.312 & & 0.583 & & 0.590 \\
\hline
\end{tabular}

Notes: the dependent variable is log patents per million population taken from Economist Intelligence Unit (2007, 2009). Individualism is Hofstede's index of individualism. A larger value of the index corresponds to a greater level of individualism. Protection against expropriation risk, taken from the International Country Risk Guide, is averaged between 1985 and 2009. It is the same variable Acemoglu et al. (2001) used to approximate the strength of a country's institutions. A larger value of the index corresponds to a greater strength of institutions. The instrument is blood distance, the Mahalanobis distance of frequency of blood types A and B in a given country relative to the frequency of blood types A and B in the U.K. The instrument for institutions (Economic Risk) is Settler mortality from Acemoglu et al. (2001) and Settler mortality (Albouy) from Albouy (2011). The instrumented variables are in bold. Controls include a dummy for landlocked countries, the percentages of population practicing major religions in a country and absolute values of country longitude and latitude. Specifications in Panel B do not include controls. Robust standard errors are in parentheses. ${ }^{* *},{ }^{* *}, *$ denote significance at $0.01,0.05$, and 0.10 levels. 


\section{Appendix Table D4. Relative effects of institutions and culture on log TFP.}

Panel A: Control for protection against expropriation risks.

\begin{tabular}{|c|c|c|c|c|c|c|c|}
\hline & \multicolumn{3}{|c|}{ OLS } & \multicolumn{4}{|c|}{ IV } \\
\hline & (1) & (2) & (3) & (4) & (5) & (6) & (7) \\
\hline Individualism & $\begin{array}{l}0.006^{*} \\
(0.003)\end{array}$ & & $\begin{array}{l}0.013 * * * \\
(0.003)\end{array}$ & $\begin{array}{l}0.020 * * * \\
(0.006)\end{array}$ & $\begin{array}{l}0.030 * * * \\
(0.010)\end{array}$ & $\begin{array}{l}0.025^{* * *} \\
(0.006)\end{array}$ & $\begin{array}{l}0.027 * * * \\
(0.006)\end{array}$ \\
\hline $\begin{array}{l}\text { Protection against } \\
\text { expropriation risk }\end{array}$ & $\begin{array}{l}0.061^{* * *} \\
(0.019)\end{array}$ & $\begin{array}{l}0.078 * * * \\
(0.015)\end{array}$ & & $\begin{array}{l}0.020 \\
(0.024) \\
\end{array}$ & $\begin{array}{l}0.003 \\
(0.023) \\
\end{array}$ & $\begin{array}{l}0.040^{* *} \\
(0.018)\end{array}$ & $\begin{array}{l}0.049^{* *} \\
(0.019)\end{array}$ \\
\hline Continent dummies & No & No & No & No & Yes & No & Yes \\
\hline Controls & No & No & No & No & No & Yes & Yes \\
\hline Observations & 75 & 75 & 75 & 75 & 75 & 75 & 75 \\
\hline $\mathrm{R}^{2}$ & 0.320 & 0.291 & 0.204 & 0.164 & 0.221 & 0.569 & 0.668 \\
\hline $1^{\text {st }}$ stage F-stat & & & & 32.52 & 16.91 & 24.13 & 21.69 \\
\hline $1^{\text {st }}$ stage partial $R^{2}$ & & & & 0.334 & 0.214 & 0.333 & 0.300 \\
\hline
\end{tabular}

Panel B: Instrument and control for protection against expropriation risks

\begin{tabular}{|c|c|c|c|c|c|c|c|c|}
\hline & \multirow{2}{*}{\multicolumn{3}{|c|}{ OLS }} & \multicolumn{5}{|c|}{ IV } \\
\hline & & & & $\begin{array}{c}\text { Blood } \\
\text { Distance }\end{array}$ & $\begin{array}{l}\text { Settler } \\
\text { mortality }\end{array}$ & $\begin{array}{c}\text { Blood } \\
\text { Distance } \\
+ \\
\text { Settler } \\
\text { mortality }\end{array}$ & $\begin{array}{c}\text { Settler } \\
\text { mortality } \\
\text { (Albouy) }\end{array}$ & $\begin{array}{c}\text { Blood } \\
\text { Distance } \\
+ \\
\text { Settler } \\
\text { mortality } \\
\text { (Albouy) }\end{array}$ \\
\hline & (1) & $(2)$ & (3) & (4) & (5) & (7) & (8) & (9) \\
\hline Individualism & $\begin{array}{l}0.010 * * * \\
(0.003)\end{array}$ & & $\begin{array}{l}0.006 \\
(0.004)\end{array}$ & $\begin{array}{l}0.020 * * * \\
(0.007)\end{array}$ & & $\begin{array}{l}0.013 \\
(0.015)\end{array}$ & & $\begin{array}{l}-0.024 \\
(0.100)\end{array}$ \\
\hline $\begin{array}{l}\text { Protection against } \\
\text { expropriation risk }\end{array}$ & & $\begin{array}{l}0.073^{* *} \\
(0.029)\end{array}$ & $\begin{array}{l}0.055 \\
(0.034)\end{array}$ & & $\begin{array}{l}0.166 * * * \\
(0.054)\end{array}$ & $\begin{array}{l}0.086 \\
(0.112)\end{array}$ & $\begin{array}{l}0.326 * \\
(0.172)\end{array}$ & $\begin{array}{l}0.537 \\
(1.074)\end{array}$ \\
\hline Observations & 37 & 37 & 38 & 37 & 37 & 37 & 37 & 37 \\
\hline $\mathrm{R}^{2}$ & 0.131 & 0.173 & 0.221 & 0.002 & -0.101 & 0.065 & -1.880 & -5.472 \\
\hline \multicolumn{9}{|l|}{$1^{\text {st }}$ stage: } \\
\hline \multicolumn{9}{|c|}{ Protection against expropriation risk } \\
\hline F-stat & & & & & 18.84 & 10.43 & 2.684 & 3.560 \\
\hline Partial $\mathrm{R}^{2}$ & & & & & 0.448 & 0.452 & 0.118 & 0.168 \\
\hline \multicolumn{9}{|l|}{ Individualism } \\
\hline F-stat & & & & 10.28 & & 14.15 & & 9.397 \\
\hline Partial $\mathrm{R}^{2}$ & & & & 0.319 & & 0.553 & & 0.430 \\
\hline
\end{tabular}

Notes: the dependent variable is log patents per million population taken from Economist Intelligence Unit (2007, 2009). Individualism is Hofstede's index of individualism. A larger value of the index corresponds to a greater level of individualism. Protection against expropriation risk, taken from the International Country Risk Guide, is averaged between 1985 and 2009. It is the same variable Acemoglu et al. (2001) used to approximate the strength of a country's institutions. A larger value of the index corresponds to a greater strength of institutions. The instrument is blood distance, the Mahalanobis distance of frequency of blood types A and B in a given country relative to the frequency of blood types A and B in the U.K. The instrument for institutions (Economic Risk) is Settler mortality from Acemoglu et al. (2001) and Settler mortality (Albouy) from Albouy (2011). The instrumented variables are in bold. Controls include a dummy for landlocked countries, the percentages of population practicing major religions in a country and absolute values of country longitude and latitude. Specifications in Panel B do not include controls. Robust standard errors are in parentheses. ${ }^{* *},{ }^{* *}, *$ denote significance at $0.01,0.05$, and 0.10 levels. 
Appendix Figure D1. Output per work and individualism by share of indigenous (as of year 1500) population.
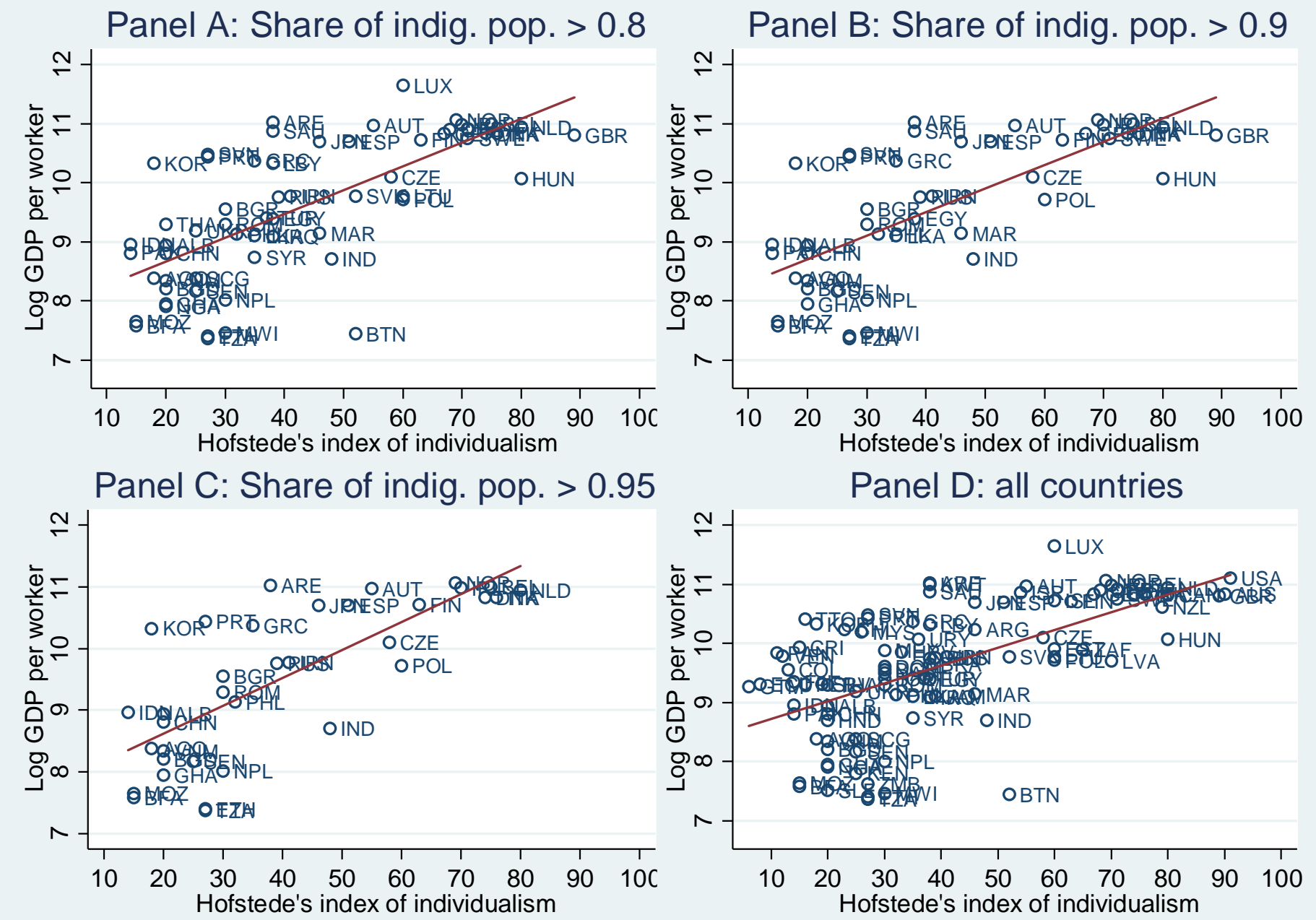

Notes: The figure shows the relationship between output per worker and individualism scores by subsets of countries with different shares of indigenous (as of year 1500) population in the modern population. The distribution of countries by the share is as follows. Share of indigenous population is $>\mathbf{9 5 \%}$ : Albania, Angola, Austria, Bangladesh, Belgium, Bulgaria, Burkina Faso, China, Czech Republic, Denmark, Ethiopia, Finland, Ghana, Greece, India, Indonesia, Iran, Ireland, Italy, Japan, Republic of Korea, Mozambique, Nepal, the Netherlands, Norway, Philippines, Poland, Portugal, Romania, Russia, Senegal, Spain, Tanzania, United Arab Emirates, Vietnam. Share of indigenous population is $>\mathbf{9 0 \%}$ and $\leq \mathbf{9 5} \%$ : Egypt, Germany, Hungary, Malawi, Morocco, Pakistan, Saudi Arabia, Slovenia, Sri Lanka, Sweden, United Kingdom. Share of indigenous population is $>\mathbf{8 0} \%$ and $\leq$ $\mathbf{9 0} \%$ : Bhutan, France, Iraq, Libya, Lithuania, Luxembourg, Nigeria, Serbia and Montenegro, Slovak Republic, Switzerland, Syria, Thailand, Turkey, Ukraine. 


\section{Appendix E}

\section{Alternative measures of cultural attributes}

In this appendix, we use an alternative data base established by cross-cultural psychologist Shalom Schwartz, built with the purpose of establishing a core set of values that have a common cross-cultural meaning. Schwartz $(1994,2006)$ gathered survey responses from K-12 schoolteachers and college students for a total of 195 samples drawn from 78 nations and 70 cultural groups between 1998 and 2000.Each sample generally consists of 180-280 respondents for a total of over 75,000 responses. Schwartz's value survey consists of 56-57 value items that ask respondents to indicate the importance of each as "a guiding principle in $m y$ life." These items have an equivalent meaning across cultures and are then used to create cultural mappings. In particular, similarly to the individualistic-collectivist dimension of cultures in Hofstede (2001), Schwartz differentiates cultures along the autonomy and embeddedness dimensions. In autonomous cultures, people are viewed as autonomous, bounded entities. They are encouraged to cultivate and express their own preferences, feelings, ideas, and abilities, and to find meaning in their own uniqueness by pursuing their own ideas and intellectual directions independently (intellectual autonomy) and by pursuing positive experiences for themselves (affective autonomy). In contrast, meaning in life for people in embedded cultures comes largely through social relationships, through identifying with the group, participating in its shared way of life, and striving toward its shared goals. Embedded cultures emphasize maintaining the status quo and restraining actions that might disrupt in-group solidarity or the traditional order. Countries that score high on embeddedness also score low on intellectual and affective autonomy. Although measures of individualism in Hofstede and Schwartz are based on different sources and indentifying procedures, the correlation between Hofstede's individualism score and Schwartz's embeddedness and autonomy scores is fairly high, ranging between 0.55 and 0.65 . The key advantage of using Hofstede's measure relative to Schwartz's measures is that Hofstede's measure of individualism is one-dimensional while Schwartz uses three (correlated) variables. Similar to Hofstede's measure, Schwartz' measures are highly collated with blood distance (see Appendix Figure E1).

Appendix Figure E1.
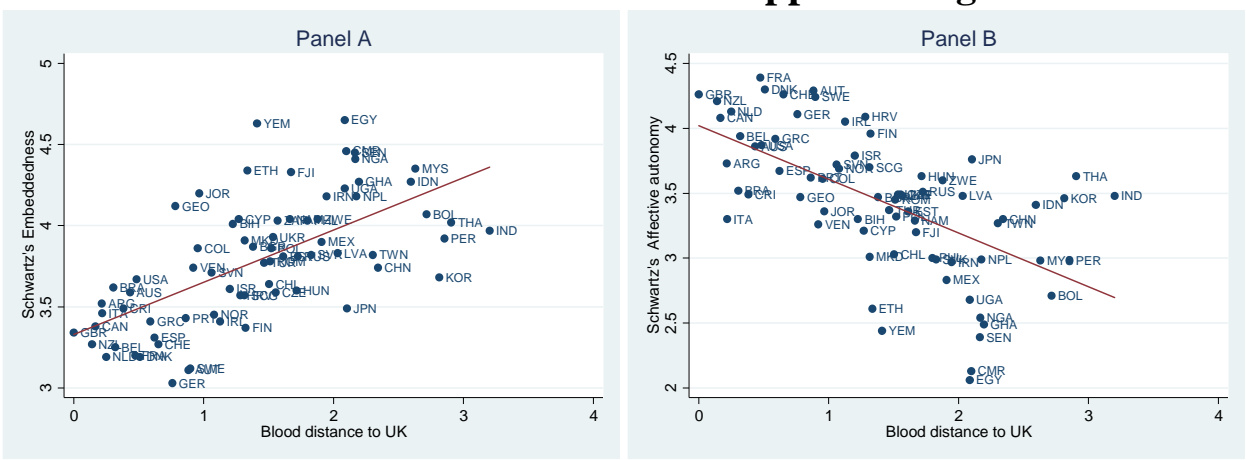

Panel C

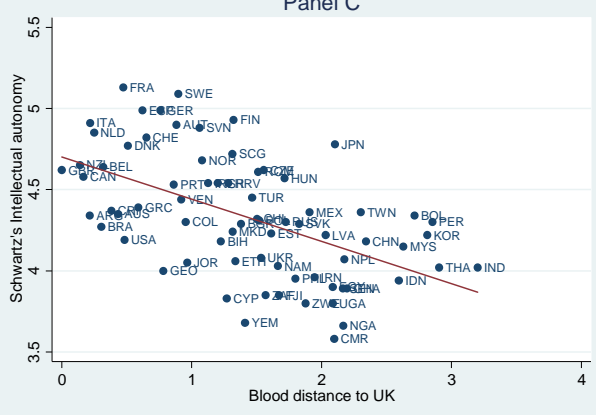

Notes: Individualism is Hofstede's index of individualism. A larger value of the index corresponds to a greater level of individualism. Intellectual autonomy encourages individuals to pursue their own ideas and intellectual directions independently. Affective autonomy encourages individuals to pursue affectively positive experience for themselves. In Embeddedness cultures, people are viewed as entities embedded in the collectivity. A larger value of Intellectual autonomy and Affective autonomy corresponds to a greater level of individualism. A smaller value of Embeddedness corresponds to a greater level of individualism. Schwartz's Intellectual autonomy, Affective autonomy, and Embeddedness are taken from Licht et al. (2007). Blood distance to UK is the Mahalanobis distance of frequency of blood types A and B in a given country relative to the frequency of blood types A and B in the U.K. 
We explore in Table E.1 if our basic results are sensitive to alternative measures of individualism. Specifically, we re-run specification (1) using Schwartz's embeddedness and autonomy measures as the dependent variables. We find that individualism leads to higher levels of income.

Table E1. Income and alternative measures of individualism (Schwartz).

\begin{tabular}{|c|c|c|c|c|c|c|}
\hline & $\begin{array}{c}\text { OLS } \\
(1) \\
\end{array}$ & $\begin{array}{l}\text { IV } \\
(2) \\
\end{array}$ & $\begin{array}{c}\text { OLS } \\
(3) \\
\end{array}$ & $\begin{array}{l}\text { IV } \\
\text { (4) } \\
\end{array}$ & $\begin{array}{c}\text { OLS } \\
(5) \\
\end{array}$ & $\begin{array}{l}\text { IV } \\
(6) \\
\end{array}$ \\
\hline Embeddedness & $\begin{array}{l}-1.915^{* * *} \\
(0.196)\end{array}$ & $\begin{array}{l}-2.185 * * * \\
(0.264)\end{array}$ & & & & \\
\hline Affective autonomy & & & $\begin{array}{l}1.305^{* * *} \\
(0.154)\end{array}$ & $\begin{array}{l}1.708 * * * \\
(0.253)\end{array}$ & & \\
\hline Intellectual autonomy & & & & & $\begin{array}{l}1.809^{* * *} \\
(0.203)\end{array}$ & $\begin{array}{l}2.688^{* * *} \\
(0.345) \\
\end{array}$ \\
\hline Observations & 71 & 71 & 71 & 71 & 71 & 71 \\
\hline $\mathrm{R}^{2}$ & 0.625 & 0.612 & 0.545 & 0.493 & 0.509 & 0.389 \\
\hline $1^{\text {st }}$ stage F-stat & & 53.47 & & 31.97 & & 38.86 \\
\hline $1^{\text {st }}$ stage partial $\mathrm{R}^{2}$ & & 0.414 & & 0.361 & & 0.300 \\
\hline
\end{tabular}

Notes: the dependent variable is log income (at purchasing power parity) per worker in 2000 from the Penn World Tables. Intellectual autonomy encourages individuals to pursue their own ideas and intellectual directions independently. Affective autonomy encourages individuals to pursue affectively positive experience for themselves. In Embeddedness cultures, people are viewed as entities embedded in the collectivity. A larger value of Intellectual autonomy and Affective autonomy corresponds to a greater level of individualism. A smaller value of Embeddedness corresponds to a greater level of individualism. Schwartz's Intellectual autonomy, Affective autonomy, and Embeddedness are taken from Licht et al. (2007). The instrument is the Mahalanobis distance of frequency of blood types A and B in a given country relative to the frequency of blood types A and B in the U.K. Specifications in columns (1)-(6) do not include controls. Robust standard errors are in parentheses. $* * *, * * *$ denote significance at $0.01,0.05$, and 0.10 levels. 


\section{Appendix F}

This appendix lists sources for constructing frequency of $\mathrm{G}$ allele in polymorphism A118G in $\mu$-opoid receptor gene for various countries. We enhance the initial compilation of this information in Way and Liebermann (2010) by increasing the coverage of countries and improving the precision of information. Specifically, we utilize additional and subsequent studies reporting this genetic information for various countries. In case of multiple studies/samples for a given country, we use a weighted average of the reported frequencies where the weight of a study is the number of subjects in the study. Thus, we assign a larger weight to studies with a greater number of subjects. This approach reduces noise in the estimated frequencies.

\begin{tabular}{|c|c|c|c|}
\hline country & $\begin{array}{l}\text { Frequency of } \mathrm{G} \\
\text { allele in } \\
\text { polymorphism } \\
\text { A118G in } \mu \text {-opoid } \\
\text { receptor gene }\end{array}$ & Citation & Sample size \\
\hline Austria & 0.14 & $\begin{array}{l}\text { Beer, B., Erb, R., Pavlic, M., Ulmer, H., Giacomuzzi, S., Riemer, } \\
\text { Y., \& Oberacher, H. 2013. Association of Polymorphisms in } \\
\text { Pharmacogenetic Candidate Genes (OPRD1, GAL, ABCB1, } \\
\text { OPRM1) with Opioid Dependence in European Population: A } \\
\text { Case-Control Study. PLoS ONE, 8(9), e75359. }\end{array}$ & 142 \\
\hline Brazil & 0.16 & $\begin{array}{l}\text { Daher, M., Costa, F. M. M. and Neves, F. A. R. 2013, Genotyping } \\
\text { the Mu-Opioid Receptor A118G Polymorphism Using the Real- } \\
\text { time Amplification Refractory Mutation System: Allele Frequency } \\
\text { Distribution Among Brazilians. Pain Practice, 13: 614-620. }\end{array}$ & 200 \\
\hline Bulgaria & 0.138 & $\begin{array}{l}\text { Momchil A. Nikolov, Olga Beltcheva, Antoaneta Galabova, Anna } \\
\text { Ljubenova, Elena Jankova, Galin Gergov, Atanas A. Russev, } \\
\text { Michael T. Lynskey, Elliot C. Nelson, Eleonora Nesheva, Dorita } \\
\text { Krasteva, Philip Lazarov, Vanio I. Mitev, Ivo M. Kremensky, } \\
\text { Radka P. Kaneva, Alexandre A. Todorov. 2011. No evidence of } \\
\text { association between 118A\&gt;G OPRM1 polymorphism and heroin } \\
\text { dependence in a large Bulgarian case-control sample, Drug and } \\
\text { Alcohol Dependence, 117(1): 62-65. }\end{array}$ & 1451 \\
\hline \multirow{5}{*}{ China } & 0.313 & $\begin{array}{l}\text { Inomata S. and Tanaka M. 2014. Comparison of allele frequencies } \\
\text { in opioid receptor gene OPRM1 (6q24-25, A118G) among different } \\
\text { racial population groups, and the effects of the genetic } \\
\text { polymorphism on } \mu \text {-opioid receptor agonist requirements: 9AP1-3. } \\
\text { European Journal of Anaesthesiology. 31: } 141 \text {. }\end{array}$ & 174 \\
\hline & 0.49 & $\begin{array}{l}\text { Ding, S., Chen, B., Zheng, Y., Lu, Q., Liu, L., \& Zhuge, Q.-C. } \\
\text { 2013. Association study of OPRM1 polymorphisms with } \\
\text { Schizophrenia in Han Chinese population. BMC Psychiatry, 13, } \\
\text { 107. }\end{array}$ & 264 \\
\hline & 0.349 & $\begin{array}{l}\text { Hung, C.C., Chiou, M.H., Huang, B.H., Hsieh, Y.W., Hsieh, T.J., } \\
\text { Huang, C.L., and Lane H.Y. 2011. Impact of genetic } \\
\text { polymorphisms in ABCB1, CYP2B6, OPRM1, ANKK1 and DRD2 } \\
\text { genes on methadone therapy in Han Chinese patients. } \\
\text { Pharmacogenomics, 12, pp. 1525-1533. }\end{array}$ & 202 \\
\hline & 0.351 & $\begin{array}{l}\text { Tan E.C., Tan C.H., Karupathivan U., and Yap E.P. 2003. Mu } \\
\text { opioid receptor gene polymorphisms and heroin dependence in } \\
\text { Asian populations. Neuroreport. } 14(4), 569-72 .\end{array}$ & 156 \\
\hline & 0.3 & $\begin{array}{l}\text { Li T., Liu XH., Zhu ZH., Zhao JH., Hu X., Sham PC., and Collier } \\
\text { DA. 2005. Association analysis of polymorphisms in the mu opioid } \\
\text { gene and heroin abuse in Chinese subjects. Addiction } \\
\text { Biology. 5:181-186. }\end{array}$ & 258 \\
\hline
\end{tabular}




\begin{tabular}{|c|c|c|c|}
\hline & 0.364 & $\begin{array}{l}\text { Lotsch J, Skarke C, Liefhold J, Geisslinger G. 2004. Genetic } \\
\text { predictors of the clinical response to opioid analgesics: clinical } \\
\text { utility and future perspectives. Clin Pharmacokinet. 15: 983-1013. }\end{array}$ & 434 \\
\hline Croatia & 0.133 & $\begin{array}{l}\text { B. Cupic, J. Stefulj, E. Zapletal, A. Matosic, T. Bordukalo-Niksic, } \\
\text { L. Cicin-Sain, and J. Gabrilovac. 2013. Opioid system genes in } \\
\text { alcoholism: a case-control study in Croatian population } \\
\text { Neuropeptides, } 47: 315-319 \text {. }\end{array}$ & 357 \\
\hline $\begin{array}{l}\text { Czech } \\
\text { Republic }\end{array}$ & 0.12 & $\begin{array}{l}\text { Serý O., Prikryl R., Castulík L. and St'astný F. 2010. A118G } \\
\text { polymorphism of OPRM1 gene is associated with schizophrenia. } J \\
\text { Mol Neurosci. 41(1): 219-222. }\end{array}$ & 452 \\
\hline \multirow[b]{2}{*}{ Denmark } & 0.1365 & $\begin{array}{l}\text { Zwisler, S. T., Enggaard, T. P., Noehr-Jensen, L., Mikkelsen, S., } \\
\text { Verstuyft, C., Becquemont, L., Sindrup, S. H. and Brosen, K. 2010, } \\
\text { The antinociceptive effect and adverse drug reactions of oxycodone } \\
\text { in human experimental pain in relation to genetic variations in } \\
\text { the OPRM1 and ABCB1genes. Fundamental \& Clinical } \\
\text { Pharmacology, 24: 517-524. }\end{array}$ & 33 \\
\hline & 0.0536 & $\begin{array}{l}\text { Ravn, P., Foster, D. J.R., Kreilgaard, M., Christrup, L., Werner, M. } \\
\text { U., Secher, E. L., Skram, U. and Upton, R. 2014, Pharmacokinetic- } \\
\text { Pharmacodynamic Modelling of the Analgesic and } \\
\text { Antihyperalgesic Effects of Morphine after Intravenous Infusion. } \\
\text { Human Volunteers. Basic \& Clinical Pharmacology \& Toxicology, } \\
\text { 115: 257-267. }\end{array}$ & 28 \\
\hline Estonia & 0.139 & $\begin{array}{l}\text { Kidd K. K., Rajeevan H., Osier M. V., Cheung K. H., Deng H., } \\
\text { Druskin L., Heinzen R., Kidd J. R., Stein S., Pakstis A. J., Tosches } \\
\text { N. P., Yeh C. C., and Miller P. L. 2003. "ALFRED - the ALlele } \\
\text { FREquency Database - update." Am J Phys Anthropol. Annual } \\
\text { Meeting Issue: Supplement. S36:128. }\end{array}$ & 1952 \\
\hline Ethiopia & 0.17 & $\begin{array}{l}\text { Lotsch J., Skarke C., Liefhold J., and Geisslinger G. 2004. Genetic } \\
\text { predictors of the clinical response to opioid analgesics: clinical } \\
\text { utility and future perspectives. Clin Pharmacokinet. 43(14):983- } \\
1013 \text {. }\end{array}$ & 49 \\
\hline \multirow{3}{*}{ Finland } & 0.111 & $\begin{array}{l}\text { Daher, M., Costa, F. M. M. and Neves, F. A. R. 2013. Genotyping } \\
\text { the Mu-Opioid Receptor A118G Polymorphism Using the Real- } \\
\text { time Amplification Refractory Mutation System: Allele Frequency } \\
\text { Distribution Among Brazilians. Pain Practice, 13: 614-620. }\end{array}$ & 184 \\
\hline & 0.186 & $\begin{array}{l}\text { Rouvinen-Lagerstrom N., Lahti J., Alho H., Leena K., Aalto M., } \\
\text { Partonen T., Silander K., Sinclair D., Räikkönen K., Erikson J. G., } \\
\text { Palotie A., Koskinen S. and Saarikoski S.T. 2013. mu-Opioid } \\
\text { receptor gene (OPRM1) polymorphism A118G: Lack of } \\
\text { Association in Finnish Populations with Alcohol Dependence or } \\
\text { Alcohol Consumption. 48(5): 519-525. }\end{array}$ & 2360 \\
\hline & 0.19 & $\begin{array}{l}\text { Rouvinen-Lagerstrom N, Lahti J, Alho H, Leena K, Aalto M, } \\
\text { Partonen T, Silander K, Sinclair D, Räikkönen K, Erikson J. G., } \\
\text { Palotie A., Koskinen S and Saarikoski S.T. 2013. mu-Opioid } \\
\text { receptor gene (OPRM1) polymorphism A118G: Lack of } \\
\text { Association in Finnish Populations with Alcohol Dependence or } \\
\text { Alcohol Consumption. 48(5): 519-525. }\end{array}$ & 1393 \\
\hline France & 0.14 & $\begin{array}{l}\text { Kidd K. K., Rajeevan H., Osier M. V., Cheung K. H., Deng H., } \\
\text { Druskin L., Heinzen R., Kidd J. R., Stein S., Pakstis A. J., Tosches } \\
\text { N. P., Yeh C. C., and Miller P. L. 2003. "ALFRED - the ALlele } \\
\text { FREquency Database - update." Am J Phys Anthropol. Annual } \\
\text { Meeting Issue: Supplement. S36:128. }\end{array}$ & 58 \\
\hline Germany & 0.1205 & $\begin{array}{l}\text { Franke, P., Wang, T., Nöthen, M. M., Knapp, M., Neidt, H., } \\
\text { Albrecht, S., Jahnes, E., Propping, P. and Maier, W. 2001, } \\
\text { Nonreplication of association between } \mu \text {-opioid-receptor gene } \\
\text { (OPRM1) A118G polymorphism and substance dependence. } A m . J .\end{array}$ & 365 \\
\hline
\end{tabular}




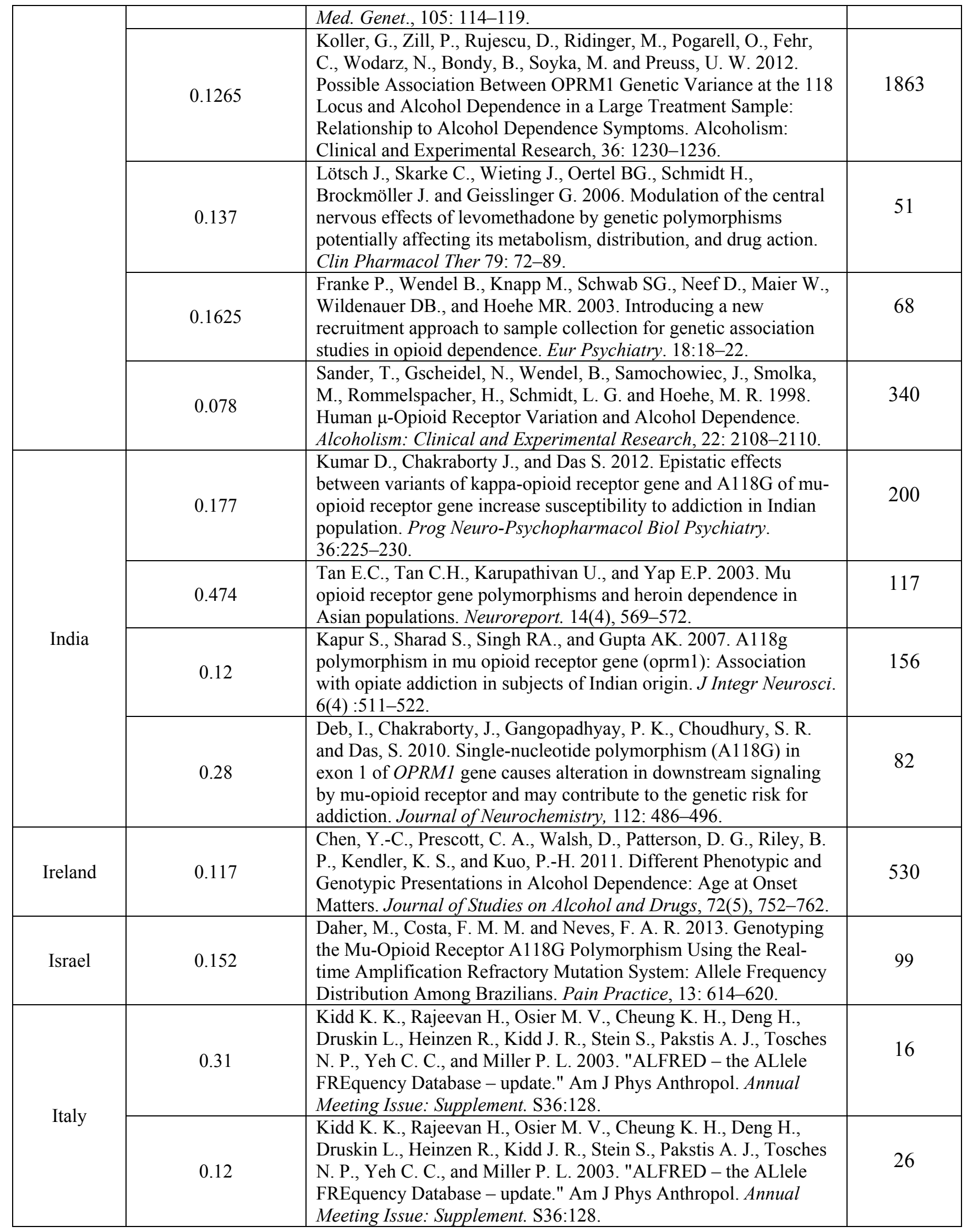




\begin{tabular}{|c|c|c|c|}
\hline & 0.138 & $\begin{array}{l}\text { Daher, M., Costa, F. M. M. and Neves, F. A. R. 2013. Genotyping } \\
\text { the Mu-Opioid Receptor A118G Polymorphism Using the Real- } \\
\text { time Amplification Refractory Mutation System: Allele Frequency } \\
\text { Distribution Among Brazilians. Pain Practice, 13: 614-620. }\end{array}$ & 214 \\
\hline & 0.149 & $\begin{array}{l}\text { Bertoletti E., Zanoni A., Giorda R., and Battaglia M. } 2012 . \\
\text { Influence of the OPRM1 gene polymorphism upon children's } \\
\text { degree of withdrawal and brain activation in response to facial } \\
\text { expressions. Developmental Cognitive Neuroscience, 2(1): 103- } \\
109 .\end{array}$ & 47 \\
\hline \multirow{10}{*}{ Japan } & 0.449 & $\begin{array}{l}\text { Inomata S. and Tanaka M. 2014. Comparison of allele frequencies } \\
\text { in opioid receptor gene OPRM1 (6q24-25, A118G) among different } \\
\text { racial population groups, and the effects of the genetic } \\
\text { polymorphism on } \mu \text {-opioid receptor agonist requirements: 9AP1-3. } \\
\text { European Journal of Anaesthesiology. 31: } 141 \text {. }\end{array}$ & 1300 \\
\hline & 0.38 & $\begin{array}{l}\text { Kidd K. K., Rajeevan H., Osier M. V., Cheung K. H., Deng H., } \\
\text { Druskin L., Heinzen R., Kidd J. R., Stein S., Pakstis A. J., Tosches } \\
\text { N. P., Yeh C. C., and Miller P. L. 2003. "ALFRED - the ALlele } \\
\text { FREquency Database - update." Am J Phys Anthropol. Annual } \\
\text { Meeting Issue: Supplement. S36:128. }\end{array}$ & 56 \\
\hline & 0.4375 & $\begin{array}{l}\text { Daher, M., Costa, F. M. M. and Neves, F. A. R. 2013. Genotyping } \\
\text { the Mu-Opioid Receptor A118G Polymorphism Using the Real- } \\
\text { time Amplification Refractory Mutation System: Allele Frequency } \\
\text { Distribution Among Brazilians. Pain Practice, 13: 614-620. }\end{array}$ & 280 \\
\hline & 0.42565 & $\begin{array}{l}\text { Nishizawa D., Han W., Hasegawa J., Ishida T., Numata Y., Sato T., } \\
\text { Kawai A., and Ikeda K. 2006. Association of mu-opioid receptor } \\
\text { gene polymorphism A118G with alcohol dependence in a Japanese } \\
\text { population. Neuropsychobiology. 53(3): 137-141. }\end{array}$ & 74 \\
\hline & 0.471 & $\begin{array}{l}\text { Ono T., Muto A., Kaneda T., Arita E., and Yoshida T. 2009. Novel } \\
\text { linkage disequilibrium of single nucleotide polymorphisms in the } \\
\text { transcriptional regulatory region of mu-opioid receptor gene in } \\
\text { Japanese population. Biol Pharm Bull. 32: 721-723. }\end{array}$ & 52 \\
\hline & 0.485 & $\begin{array}{l}\text { Gelernter J., Kranzler H., and Cubells J. 1999. Genetics of two mu } \\
\text { opioid receptor gene (OPRM1) exon I polymorphisms: population } \\
\text { studies, and allele frequencies in alcohol- and drug-dependent } \\
\text { subjects. Molecular Psychiatry. 4: 476-483. }\end{array}$ & 34 \\
\hline & 0.431 & $\begin{array}{l}\text { Lotsch J, Skarke C, Liefhold J, Geisslinger G. 2004. Genetic } \\
\text { predictors of the clinical response to opioid analgesics: clinical } \\
\text { utility and future perspectives. Clin Pharmacokinet. 15: } 983-1013 \text {. }\end{array}$ & 216 \\
\hline & 0.467 & $\begin{array}{l}\text { Matsunaga M., Isowa T., Murakami H., Kasugai K., Yoneda M., } \\
\text { Kaneko H., and Ohira H. 2009. Association of polymorphism in the } \\
\text { human mu-opioid receptor OPRM1 gene with proinflammatory } \\
\text { cytokine levels and health perception. Brain Behav Immun. 23:931- } \\
\text { 935. }\end{array}$ & 123 \\
\hline & 0.453 & $\begin{array}{l}\text { Ide S., Kobayashi H., Tanaka K., Ujike H., Sekine Y., Ozaki N., } \\
\text { Inada T., Harano M., Komiyama T., Yamada M., Iyo M., Ikeda K. } \\
\text { and Sora I. 2004. Gene Polymorphisms of the Mu Opioid Receptor } \\
\text { in Methamphetamine Abusers. Annals of the New York Academy of } \\
\text { Sciences. 1025: 316-324. }\end{array}$ & 213 \\
\hline & 0.452 & $\begin{array}{l}\text { Hishimoto A., Cui H., Mouri K., Nushida H., Ueno Y., Maeda K., } \\
\text { and Shirakawa O. 2008. A functional polymorphism of the micro- } \\
\text { opioid receptor gene is associated with completed suicides. } J \\
\text { Neural Transm. 115: 531-536. }\end{array}$ & 374 \\
\hline $\begin{array}{c}\text { Korea, } \\
\text { Republic of }\end{array}$ & 0.368 & $\begin{array}{l}\text { Kidd K. K., Rajeevan H., Osier M. V., Cheung K. H., Deng H., } \\
\text { Druskin L., Heinzen R., Kidd J. R., Stein S., Pakstis A. J., Tosches } \\
\text { N. P., Yeh C. C., and Miller P. L. 2003. "ALFRED - the ALlele } \\
\text { FREquency Database - update." Am J Phys Anthropol. Annual }\end{array}$ & 106 \\
\hline
\end{tabular}




\begin{tabular}{|c|c|c|c|}
\hline & & Meeting Issue: Supplement. S36:128. & \\
\hline & 0.371 & $\begin{array}{l}\text { Kim SA., Kim JW., Song JY., Park S., Lee HJ., Chung JH. } 2004 . \\
\text { Association of polymorphisms in nicotinic acetylcholine receptor } \\
\text { alpha4 subunit gene (CHRNA4), mu-opioid receptor gene } \\
\text { (OPRM1), and ethanol-metabolizing enzyme genes with alcoholism } \\
\text { in Korean patients Alcohol. 34: 115-120. }\end{array}$ & 128 \\
\hline & 0.311 & $\begin{array}{l}\text { Kim SG., Kim CM., Kang DH., Kim YJ., Byun WT., Kim SY., } \\
\text { Park JM., Kim MJ., and Oslin DW. 2004. Association of functional } \\
\text { opioid receptor genotypes with alcohol dependence in } \\
\text { Koreans. Alcohol Clin Exp Res. 28: } 986-990 .\end{array}$ & 140 \\
\hline \multirow{2}{*}{ Malaysia } & 0.27 & $\begin{array}{l}\text { Nagaya D., Ramanathan S., Ravichandran M., and Navaratnam V. } \\
\text { 2012. A118G mu opioid receptor polymorphism among drug } \\
\text { addicts in Malaysia. J Integr Neurosci. 11(1): 117-122. }\end{array}$ & 80 \\
\hline & 0.45 & $\begin{array}{l}\text { Tan E.C., Tan C.H., Karupathivan U., and Yap E.P. 2003. Mu } \\
\text { opioid receptor gene polymorphisms and heroin dependence in } \\
\text { Asian populations. Neuroreport. 14(4), 569-572. }\end{array}$ & 131 \\
\hline \multirow{2}{*}{ Mexico } & 0.383 & $\begin{array}{l}\text { Archer, N .P., Wilkinson, A. V., Ranjit, N., Wang, J., Zhao, H., } \\
\text { Swann, A. C., and Shete, S. 2014. Genetic, psychosocial, and } \\
\text { demographic factors associated with social disinhibition in } \\
\text { Mexican-origin youth. Brain and Behavior. 4(4): 521-530. }\end{array}$ & 1064 \\
\hline & 0.2365 & $\begin{array}{l}\text { Du, Y., and Yvonne Wan, Y.-J. 2009. The Interaction of Reward } \\
\text { Genes With Environmental Factors in Contribution to Alcoholism } \\
\text { in Mexican Americans. Alcoholism, Clinical and Experimental } \\
\text { Research.33(12): 2103-2112. }\end{array}$ & 338 \\
\hline \multirow{5}{*}{ Netherlands } & 0.134 & $\begin{array}{l}\text { Salimi V., Hennus MP., Mokhtari-Azad T., Shokri F., Janssen R., } \\
\text { Hodemaekers HM., Rygiel TP., Coenjaerts FE., Meyaard L., and } \\
\text { Bont L. 2013. Opioid Receptors Control Viral Replication in the } \\
\text { Airways. Crit Care Med. 41: 205-214. }\end{array}$ & 930 \\
\hline & 0.178 & $\begin{array}{l}\text { Carpentier P.J., Arias Vasquez A., Hoogman M., Onnink M., Kan } \\
\text { C.C., Kooij J.J., Makkinje R., Iskandar S., Kiemeney L.A., de Jong } \\
\text { C.A., Franke B., and Buitelaar J.K. 2013. Shared and unique } \\
\text { genetic contributions to attention deficit/hyperactivity disorder and } \\
\text { substance use disorders: a pilot study of six candidate genes Eur. } \\
\text { Neuropsychopharmacol. 23(6): 448-457. }\end{array}$ & 500 \\
\hline & 0.122 & $\begin{array}{l}\text { Pieters S., van der Zwaluw C. S., van der Vorst H., Wiers R. W., } \\
\text { Smeets H., Lambrichs E., Burk W. J., Engels R. C. 2012. The } \\
\text { moderating effect of alcohol-specific parental rule-setting on the } \\
\text { relation between the dopamine D2 receptor gene (DRD2), the mu- } \\
\text { opioid receptor gene (OPRM1) and alcohol use in young } \\
\text { adolescents. Alcohol \& Alcoholism. 47: 663-670. }\end{array}$ & 196 \\
\hline & 0.108 & $\begin{array}{l}\text { Vossen, H., Kenis, G., Rutten, B., van Os, J., Hermens, H., and } \\
\text { Lousberg, R. 2010. The Genetic Influence on the Cortical } \\
\text { Processing of Experimental Pain and the Moderating Effect of Pain } \\
\text { Status. PLoS ONE, 5(10), e13641. }\end{array}$ & 37 \\
\hline & 0.115 & $\begin{array}{l}\text { Kleinjan M., Poelen EA., Engels RC., and Verhagen M. 2013. Dual } \\
\text { growth of adolescent smoking and drinking: evidence for an } \\
\text { interaction between the mu-opioid receptor (OPRM1) A118G } \\
\text { polymorphism and sex. Addict Biol. 18(6): 1003-1012. }\end{array}$ & 428 \\
\hline Norway & 0.104 & $\begin{array}{l}\text { Daher, M., Costa, F. M. M. and Neves, F. A. R. 2013. Genotyping } \\
\text { the Mu-Opioid Receptor A118G Polymorphism Using the Real- } \\
\text { time Amplification Refractory Mutation System: Allele Frequency } \\
\text { Distribution Among Brazilians. Pain Practice, 13: 614-620. }\end{array}$ & 207 \\
\hline Russia & 0.16 & $\begin{array}{l}\text { Kidd K. K., Rajeevan H., Osier M. V., Cheung K. H., Deng H., } \\
\text { Druskin L., Heinzen R., Kidd J. R., Stein S., Pakstis A. J., Tosches } \\
\text { N. P., Yeh C. C., and Miller P. L. 2003. "ALFRED - the ALlele } \\
\text { FREquency Database - update." Am J Phys Anthropol. Annual }\end{array}$ & 50 \\
\hline
\end{tabular}




\begin{tabular}{|c|c|c|c|}
\hline & & Meeting Issue: Supplement. S36:128. & \\
\hline \multirow{3}{*}{ Singapore } & 0.39 & $\begin{array}{l}\text { Tan E.C., Lim E.C., Teo Y.Y., Lim Y., Law H.Y., and Sia, A.T. } \\
\text { 2009. Ethnicity and OPRM variant independently predict pain } \\
\text { perception and patient-controlled analgesia usage for post-operative } \\
\text { pain. Molecular Pain. 5: } 32 \text {. }\end{array}$ & 994 \\
\hline & 0.4 & $\begin{array}{l}\text { Pang, G.S.Y., Ithnin, F., Wong, Y.Y., Wang, J.B., Lim, Y., Sia, } \\
\text { A.T.H., and Lee, C.G.L. 2012. A Non-Synonymous Single } \\
\text { Nucleotide Polymorphism in an OPRM1 Splice Variant Is } \\
\text { Associated with Fentanyl-Induced Emesis in Women Undergoing } \\
\text { Minor Gynaecological Surgery. PLoS ONE. 7(11): e48416. }\end{array}$ & 40 \\
\hline & 0.337 & $\begin{array}{l}\text { Sia AT, Lim Y, Lim EC, Goh RW, Law HY., Landau R., Teo YY., } \\
\text { and Tan E.C. 2008. A118G single nucleotide polymorphism of } \\
\text { human mu-opioid receptor gene influences pain perception and } \\
\text { patient-controlled intravenous morphine consumption after } \\
\text { intrathecal morphine for postcesarean } \\
\text { analgesia. Anesthesiology. 109:520-526. }\end{array}$ & 585 \\
\hline Spain & 0.137 & $\begin{array}{l}\text { Verde Z., Santiago C., Rodríguez González-Moro J. M., de Lucas } \\
\text { Ramos P., López Martín S., Bandrés F., Lucia A., and Gómez- } \\
\text { Gallego F. 2011. "Smoking Genes": A Genetic Association Study. } \\
\text { PLoS ONE. 6(10). }\end{array}$ & 80 \\
\hline \multirow{4}{*}{ Sweden } & 0.074 & $\begin{array}{l}\text { Lloret Linares C., Hajj A., Poitou C., Simoneau G., Clement K., } \\
\text { Louis Laplanche J., Lépine J., Bergmann J.F., Mouly S., and Peoc'h } \\
\text { K. 2011. Pilot study examining the frequency of several gene } \\
\text { polymorphisms involved in morphine pharmacodynamics and } \\
\text { pharmacokinetics in a morbidly obese population. Obesity Surgery. } \\
\text { 21(8): 1257-1264. }\end{array}$ & 170 \\
\hline & 0.1 & $\begin{array}{l}\text { Kakko J., von Wachenfeldt J., Svanborg K.D., Lidstrom J., Barr } \\
\text { C.S., and Heilig M. 2008. Mood and neuroendocrine response to a } \\
\text { chemical stressor, metyrapone, in buprenorphine-maintained heroin } \\
\text { dependence. Biol Psychiatry. 63(2): 172-177. }\end{array}$ & 10 \\
\hline & 0.134 & $\begin{array}{l}\text { Rhodin A., Grönbladh A., Ginya H., Nilsson K. W., Rosenblad A., } \\
\text { Zhou Q., Enlund M., Hallberg M., Gordh T., and Nyberg F. } 2013 \text {. } \\
\text { Combined analysis of circulating } \beta \text {-endorphin with gene } \\
\text { polymorphisms in OPRM1, CACNAD2 and ABCB1 reveals } \\
\text { correlation with pain, opioid sensitivity and opioid-related side } \\
\text { effects. Molecular Brain. } 6,8 \text {. }\end{array}$ & 56 \\
\hline & 0.1065 & $\begin{array}{l}\text { Pettersson F.D., Gronbladh A., Nyberg F., Sundstrom-Poromaa I., } \\
\text { and Akerud H. 2012. The A118G single-nucleotide polymorphism } \\
\text { of human mu-opioid receptor gene and use of labor analgesia. } \\
\text { Reprod Sci. 19(9): 962-967. }\end{array}$ & 672 \\
\hline \multirow[b]{2}{*}{ Taiwan } & 0.329 & $\begin{array}{l}\text { Loh, E. W., Fann, C. S. J., Chang, Y. T., Chang, C. J. and Cheng, } \\
\text { A. T. A. 2004. Endogenous Opioid Receptor Genes and Alcohol } \\
\text { Dependence Among Taiwanese Han. Alcoholism: Clinical and } \\
\text { Experimental Research. 28: 15-19. }\end{array}$ & 149 \\
\hline & 0.326 & $\begin{array}{l}\text { Tsai F.-F., Fan S.-Z., Yang Y.-M., Chien K.-L., Su Y.-N. and Chen } \\
\text { L.-K. 2010. Human opioid } \mu \text {-receptor A118G polymorphism may } \\
\text { protect against central pruritus by epidural morphine for post- } \\
\text { cesarean analgesia. Acta Anaesthesiologica Scandinavica. } \\
\text { 54(10): 1265-1269. }\end{array}$ & 217 \\
\hline Thailand & 0.438 & $\begin{array}{l}\text { Tan E.C., Tan C.H., Karupathivan U., and Yap E.P. 2003. Mu } \\
\text { opioid receptor gene polymorphisms and heroin dependence in } \\
\text { Asian populations. Neuroreport. 14(4), 569-72. }\end{array}$ & 56 \\
\hline Turkey & 0.19 & $\begin{array}{l}\text { Solak O., Erdogan M. O., Yildiz H., Ulasli A. M., Yaman F., Terzi } \\
\text { E.S. Ulu S., Dündar Ü. and Solak M. 2014. Assessment of opioid } \\
\text { receptor } \mu 1 \text { gene A118G polymorphism and its association with } \\
\text { pain intensity in patients with fibromyalgia. Rheumatology }\end{array}$ & 100 \\
\hline
\end{tabular}




\begin{tabular}{|c|c|c|c|}
\hline & & International. 34(9): 1257-1261. & \\
\hline \multirow[b]{2}{*}{$\begin{array}{l}\text { United } \\
\text { Kingdom }\end{array}$} & 0.17 & $\begin{array}{l}\text { Bunten H., Liang WJ., Pounder D. J., Seneviratne C. and Osselton } \\
\text { D. 2011. Interindividual variability in the prevalence of OPRM1 } \\
\text { and CYP2B6 gene variations may identify drug-susceptible } \\
\text { populations. J Anal Toxicol. 35(7): 431-437. }\end{array}$ & 100 \\
\hline & 0.152 & $\begin{array}{l}\text { Barratt, C., Lai, T., Nashef, L., Valentin, A., Fisniku, L., Moran, } \\
\text { N., Asherson, P. and Makoff, A. 2006. No Association of Single } \\
\text { Nucleotide Polymorphisms in the } \mu \text {-Opioid Receptor Subunit Gene } \\
\text { with Idiopathic Generalized Epilepsy. Epilepsia. 47(10): 1728- } \\
1731 .\end{array}$ & 257 \\
\hline \multirow{6}{*}{$\begin{array}{l}\text { United } \\
\text { States }\end{array}$} & 0.124 & $\begin{array}{l}\text { Daher, M., Costa, F. M. M. and Neves, F. A. R. 2013. Genotyping } \\
\text { the Mu-Opioid Receptor A118G Polymorphism Using the Real- } \\
\text { time Amplification Refractory Mutation System: Allele Frequency } \\
\text { Distribution Among Brazilians. Pain Practice, 13: 614-620. }\end{array}$ & 161 \\
\hline & 0.154 & $\begin{array}{l}\text { Gelernter J., Kranzler H., and Cubells J. 1999. Genetics of two mu } \\
\text { opioid receptor gene (OPRM1) exon I polymorphisms: population } \\
\text { studies, and allele frequencies in alcohol- and drug-dependent } \\
\text { subjects. Molecular Psychiatry. 4: 476-483. }\end{array}$ & 72 \\
\hline & 0.237 & $\begin{array}{l}\text { Daher, M., Costa, F. M. M. and Neves, F. A. R. 2013. Genotyping } \\
\text { the Mu-Opioid Receptor A118G Polymorphism Using the Real- } \\
\text { time Amplification Refractory Mutation System: Allele Frequency } \\
\text { Distribution Among Brazilians. Pain Practice, 13: 614-620. }\end{array}$ & 338 \\
\hline & 0.14 & $\begin{array}{l}\text { Gelernter J., Kranzler H., and Cubells J. 1999. Genetics of two mu } \\
\text { opioid receptor gene (OPRM1) exon I polymorphisms: population } \\
\text { studies, and allele frequencies in alcohol- and drug-dependent } \\
\text { subjects. Molecular Psychiatry. 4: 476-483. }\end{array}$ & 10 \\
\hline & 0.03 & $\begin{array}{l}\text { Crowley J. J., Oslin D. W., Patkar A. A., Gottheil E., DeMaria P. } \\
\text { A. Jr., O'Brien C. P., Berretitini W. H., and Grice D. E. 2003. A } \\
\text { genetic association study of the mu opioid receptor and severe } \\
\text { opioid dependence. Psychiatric Genetics. 13(3): 169-173. }\end{array}$ & 96 \\
\hline & 0.047 & $\begin{array}{l}\text { Gelernter J., Kranzler H., and Cubells J. 1999. Genetics of two mu } \\
\text { opioid receptor gene (OPRM1) exon I polymorphisms: population } \\
\text { studies, and allele frequencies in alcohol- and drug-dependent } \\
\text { subjects. Molecular Psychiatry. 4: 476-483. }\end{array}$ & 34 \\
\hline
\end{tabular}




\section{Appendix G}

This appendix outlines the timing and sources of the variables used in the paper.

\begin{tabular}{|c|c|c|}
\hline Variable & Sources & Timing \\
\hline Individualism & $\begin{array}{l}\text { Hosftede (2001), subsequent updates are } \\
\text { available on http://geert-hofstede.com }\end{array}$ & $\begin{array}{l}\text { The initial wave of individualism scores were } \\
\text { constructed in the } 1960 \text { s for about } 30 \text { countries. } \\
\text { Additional countries were added gradually over time. }\end{array}$ \\
\hline Frequency of blood types & $\begin{array}{l}\text { Cavalli-Sfoza, Menozzi, Piazza (1994), } \\
\text { Mourant, Kopec and Domaniewska- } \\
\text { Sobczak (1976), Tills, Kopec, and Tills } \\
\text { (1983) }\end{array}$ & $\begin{array}{l}\text { Most data on the frequencies of blood types comes } \\
\text { from 1940s and 1950s. }\end{array}$ \\
\hline Genetic data: SLC6A4 & $\begin{array}{l}\text { Chiao and Blizinsky (2009), Inglehart et } \\
\text { al. (2014) }\end{array}$ & 2000 s and 2010 s. \\
\hline Genetic data: A118G & See Appendix F & 2000s and 2010s. \\
\hline Patents per capita & Economist Intelligence Unit $(2007,2009)$ & $2000 \mathrm{~s}$ \\
\hline Total factor productivity (TFP) & $\begin{array}{l}\text { Hall and Jones (1999), Jones and Romer } \\
(2010)\end{array}$ & $\begin{array}{l}\text { We use TFP for } 1988 \text { (from Hall and Jones 1999) } \\
\text { and for year } 2000 \text { (from Jones and Romer 2010). }\end{array}$ \\
\hline Output per worker & $\begin{array}{l}\text { Penn World Tables (PWT), Maddison } \\
\text { (2003) }\end{array}$ & $\begin{array}{l}\text { We use year } 2000 \text { (from Penn World Table) in the } \\
\text { baseline. Robustness checks use output per worker } \\
\text { from Maddison (2003) which provides estimates for } \\
\text { output per worker for } 1500,1820 \text {, and } 2001 \text {. }\end{array}$ \\
\hline Ethnic shares & Fearon (2003) & Early 1990s \\
\hline Historical pathogen prevalence & $\begin{array}{l}\text { Murray and Schaller (2010), Fincher et al. } \\
\text { (2008) }\end{array}$ & Early-to-mid $20^{\text {th }}$ century \\
\hline Pronoun drop & Kashima and Kashima (1998) & $1990 \mathrm{~s}$ \\
\hline $\begin{array}{l}\text { Protection against expropriation } \\
\text { risk }\end{array}$ & International Country Risk Guide (ICRG) & Average value for $1985-2019$ \\
\hline Trust & World Values Survey & An average value across multiple waves since $1980 \mathrm{~s}$ \\
\hline Years of schooling & Barro and Lee (2001) & 1970 \\
\hline Legal origin & La Porta et al. (1998) & $1990 \mathrm{~s}$ \\
\hline Share of Europeans in 1900 & Acemoglu et al. (2001) & 1900 \\
\hline Diffusion speed & Comin and Mestieri (2013) & Since 1820 . \\
\hline
\end{tabular}

